MARCELO CRESCENTI AULICINO

ORGANIZAÇÃO NA PRODUÇÃO POR PROCESSOS CONTÍNUOS: PRÁTICA, CONCEITOS E MÉTODOS DE PROJETO PARA FRONTEIRAS MÓVEIS INTERPENETRANTES

São Paulo

Exemplar Original: 2008

Exemplar Revisado: 2008 


\title{
ORGANIZAÇÃO NA PRODUÇÃO POR PROCESSOS CONTÍNUOS: PRÁTICA, CONCEITOS E MÉTODOS DE PROJETO PARA FRONTEIRAS MÓVEIS INTERPENETRANTES
}

\author{
Tese de Doutorado apresentada à Escola \\ Politécnica da Universidade de São Paulo \\ para obtenção do título de Doutor em \\ Engenharia
}

Orientador: Prof. Dr. Mário Sérgio Salerno

\author{
Área de Concentração: \\ Engenharia de Produção
}

São Paulo

Exemplar Original: 2008

Exemplar Revisado: 2008 
Este exemplar foi revisado e alterado em relação à versão original, sob responsabilidade única do autor e com a anuência de seu orientador.

São Paulo, de maio de 2008.

Assinatura do autor

Assinatura do orientador

Aulicino, Marcelo Crescenti

Organização na produção por processos contínuos : prática, conceitos e métodos de projeto para fronteiras móveis e interpenetrantes / M.C. Aulicino. - ed.rev. -- São Paulo, 2008.

$142 \mathrm{p}$.

Tese (Doutorado) - Escola Politécnica da Universidade de São Paulo. Departamento de Engenharia de Produção.

1. Organização da produção 2. Produção contínua I. Universidade de São Paulo. Escola Politécnica. Departamento de Engenharia de Produção II. t. 


\section{DEDICATÓRIA}

Ao Raphael Augusto, que terá muitas oportunidades para "fazer a sua parte", num mundo sempre em mudanças, espero que para melhor.

A Deus, pelas muitas oportunidades e coisas boas que me deu! 


\section{AGRADECIMENTOS}

Ao Mário Sérgio Salerno, que com dedicação e amizade orientou a elaboração da tese. Seu conhecimento, experiência e apoio foram fundamentais para a conclusão deste trabalho.

Ao Roberto Marx, que discutiu comigo as elaborações iniciais deste trabalho. Seus questionamentos abriram caminho para rever e redirecionar aspectos importantes da tese.

Aos diversos colegas de Petrobrás pelas horas de entrevistas concedidas e àqueles que trocaram idéias comigo a respeito do trabalho no refino de petróleo. Citá-los nominalmente seria um risco de cometer injustiças ou esquecer alguém.

Ao Salvador Guirardo, que abriu as portas da empresa de Fertilizantes e demais profissionais dessa empresa que me atenderam com bastante atenção e cortesia.

Aos professores, colegas e funcionários do Departamento de Engenharia de Produção, pela convivência saudável e pelas oportunidades de aprender. E aos professores Gilberto e Molinari da Engenharia Mecatrônica.

À PETROBRAS S.A., pelo apoio durante o curso e elaboração da tese.

À Jacirene Galante e Vera Lucy Gonçalves pelo trabalho de formatação e edição do texto. Ao Raphael Augusto M. Aulicino pelo apoio na redação do Abstract.

À minha esposa Maria da Graça e ao meu filho Raphael Augusto, pelo apoio sempre presente, pela paciência com as inúmeras horas de estudo/pesquisa e "algum stress". 
"Em tudo que ultrapassar a rotina repetitiva, existe uma íntima parcela de novidade e de processo criador humano, estando as bases da criação, assentadas na capacidade de combinar o antigo com o novo."

Lev Semenovich Vygotsky 


\section{Resumo}

Nos processos contínuos observa-se uma forte participação da Engenharia e da Manutenção na operação dos sistemas de produção, ao mesmo tempo em que a Operação interage bastante com as atividades daquelas duas funções. Essas intervenções das funções, no que aparentemente seria do domínio organizacional das demais, acontecem em razão da complexidade tecnológica e logística desses sistemas de produção. Os estudos de casos realizados em refinaria de petróleo e em fábrica petroquímica de produtos para fertilizantes, que são casos típicos de processos contínuos, mostram que nas interfaces entre as funções Operação, Engenharia e Manutenção as fronteiras organizacionais não são fixas. Elas se movem e se interpenetram, conferindo dinâmica à estrutura organizacional para solucionar problemas, definir e implantar metas de produção.

Entretanto, a teoria para projetos organizacionais, em particular a teoria sociotécnica moderna, prevê fronteiras fixas. Neste trabalho, tendo em vista as interfaces entre as funções que atuam de modo integrado na produção por processos contínuos, essa teoria é discutida, fazendo-se as considerações pertinentes às fronteiras móveis, fruto das informações exploradas através dos casos estudados. Então são feitas proposições de cunho conceitual-metodológico para que a teoria de projetos organizacionais possa tratar as fronteiras que se movem e se interpenetram. Os conceitos propostos abrangem co-execução de atividades e compartilhamento do controle de aspectos dos sistemas de produção pela Operação, Engenharia e Manutenção, além do estabelecimento de mecanismos de coordenação para fronteiras móveis e interpenetrantes. Complementarmente, são apresentadas regras para projeto organizacional coerentes com os conceitos propostos.

Obtém-se, assim, uma teoria de projetos adequada à organização de sistemas de produção por processos contínuos, que pode ser aplicada nos sistemas de produção onde, devido à complexidade técnica, a Engenharia e a Manutenção se fazem bem presentes na operação da produção e as interfaces entre Operação, Engenharia e Manutenção têm fronteiras organizacionais móveis e interpenetrantes. 
Palavras-chave: processos contínuos, projeto organizacional, fronteiras organizacionais, coordenação. 


\begin{abstract}
In the continuous processes is observed a strong participation of the Engineering and the Maintenance at the operation of production systems, at the same time the Operation interacts very intensively with the activities of those two functions. Complex interventions involving all these three functions occur very frequently due to the technological and logistical complexity of these production systems. The case studies realized in an oil refinery and in a petrochemical factory of fertilizers products, which are typical cases of continuous processes, show that the frontiers between the Operation, Engineering and Maintenance functions are not fixed. They move and interpenetrate between themselves, resulting in a specific dynamic to the organizational structure in order to solve problems, define and achieve production goals.
\end{abstract}

However, the theory for organizational design, particularly the modern sociotechnical theory, foresees fixed frontiers. In this work, in view of the interfaces between the functions that act in an integrated way into the production continuous processes, this theory is discussed in order to propose the pertinent considerations to the moving frontiers, as a result of the exploration of the case studies. Then conceptual and methodological propositions are made so that the organizational design theory may deal with the moving and interpenetrating frontiers. The concepts proposed comprehend co-execution of the activities and sharing of the control aspects of the productions systems by Operation, Engineering and Maintenance, beyond the establishment of the coordination mechanisms for those frontiers. Complementarily, rules are presented for the organizational design effort, coherent with the considered concepts.

So, a theory of design adjusted to the organization of the continuous process production systems is developed, which can be applied into the production systems where, due to the technical complexity, Engineering and Maintenance are well presented in the production operation and the interfaces between Operation, Maintenance and Engineering have interpenetrating and moving organizational frontiers. 
Key-words: Continuous processes. Organizational design. Organizational Frontiers. Coordination. 


\section{LISTA DE FIGURAS}

Figura 4.1 - Organização estrutural do sistema de produção da RPBC .65

Figura 4.2 - Fluxograma simplificado de produção da RPBC .66

Figura 4.3 - Fluxograma simplificado de produção da Fertilizantes .70

Figura 4.4 - Organização estrutural do sistema de produção da Fertilizantes .71

Figura 5.1 - Representação ilustrativa da importância da integração entre Funções (domínios organizacionais) para o sucesso do controle de processos, conforme visão da engenharia de Automação da RPBC 


\section{LISTA DE TABELAS}

Tabela 2.1 - Roteiro para projeto organizacional do trabalho conforme a sociotecnologia moderna

Tabela 2.2 - Mecanismos de coordenação e partes da estrutura organizacional.....54

Tabela 3.1 - Variáveis de pesquisa. .58

Tabela 3.2 - Quantidade de entrevistados na RPBC por função profissional e área organizacional.

Tabela 3.3 - Quantidade de entrevistados na Fertilizantes função profissional e área organizacional.

Tabela 5.1 - Dados relativos à variável de pesquisa - identificação e relevância das interfaces

Tabela 5.2 - Dados relativos à variável de pesquisa - identificação e natureza das interfaces.

Tabela 5.3 - Dados relativos à variável de pesquisa - paralelização e Segmentação das interfaces entre Operação, Manutenção

e Engenharia. .79

Tabela 5.4 - Dados relativos à variável de pesquisa - diferenciação da Execução. 81

Tabela 5.5 - Dados relativos à variável de pesquisa - especialização da Execução 82 
Tabela 5.6 - Dados relativos à variável de pesquisa - separação das funções de execução e controle e especialização do controle

Tabela 5.7 - Dados relativos à variável de pesquisa - diferenciação do controle.....85

Tabela 6.1 - Práticas de coordenação para organização do trabalho em processos contínuos

Tabela 6.2 - Etapas para o projeto organizacional integrado para sistemas de produção contínua .. 126

Tabela 6.3 - Quadro comparativo entre a teoria para projeto organizacional de base sociotécnica moderna e as proposições para contemplar processos contínuos de produção 


\section{LISTA DE ABREVIATURAS E SIGLAS}

CETESB - Companhia de Tecnologia de Saneamento Ambiental

CNC - Comando de Controle Numérico

ECO - Equipes de Continuidade Operacional

MASP - Método de Análise e Solução de Problemas

NASA - National Aeronautics and Space Administration

PCP - Programação e Controle da Produção

PETROBRAS - Petróleo Brasileiro S.A.

RCM - Reliability Centered Maintenance

RPBC - Refinaria Presidente Bernardes - Cubatão

SDCD - Sistemas Digitais de Controle Distribuídos 


\section{SUMÁRIO}

1 INTRODUÇÃO

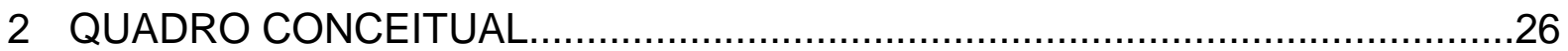

2.1 OS SISTEMAS DE PRODUÇÃO POR PROCESSOS CONTÍNUOS...................26

2.1.1 A Operação nos Processos Contínuos.........................................................28

2.1.2 A Função Manutenção na Produção por Processos Contínuos.........................31

2.1.3 A Atuação da Engenharia nos Processos Contínuos de Produção...................33

2.2 CONCEITOS E MÉTODOS PARA PROJETO DE ORGANIZAÇÃO DO

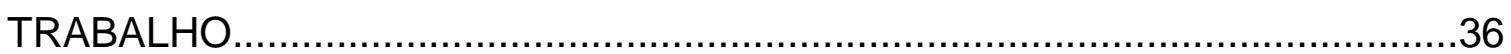

2.2.1 Teoria Sociotécnica Moderna .....................................................................

2.2.2 Conceitos do Projeto Organizacional Sociotécnico Moderno..............................40

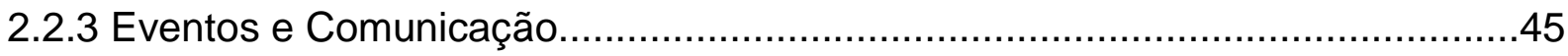

2.2.4 Espaços de Comunicação e Negociação.......................................................48

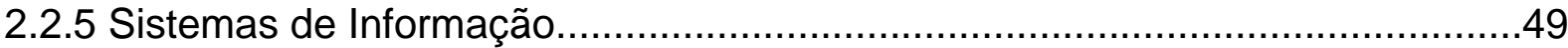

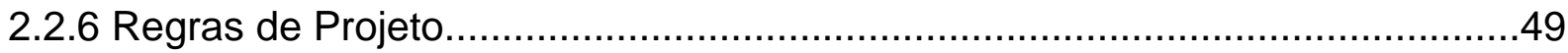

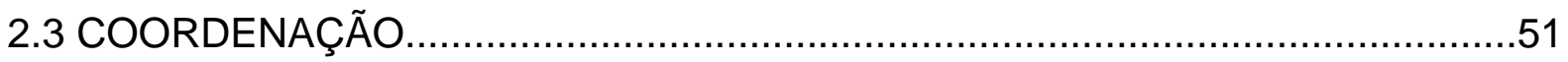

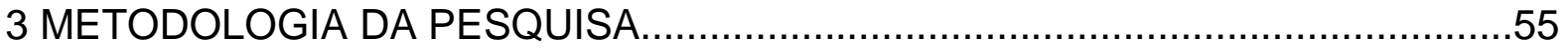

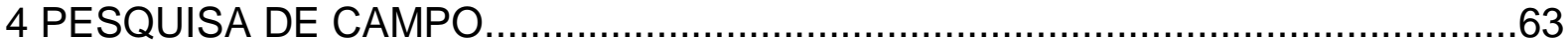

4.1 O CASO DA REFINARIA DE PETRÓLEO - RPBC.......................................64

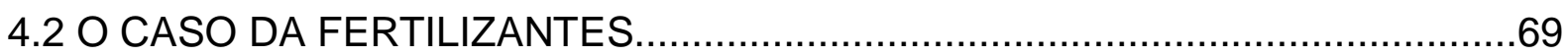

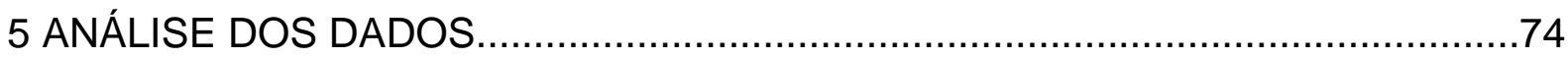

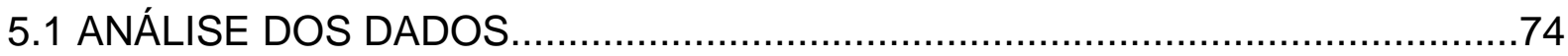

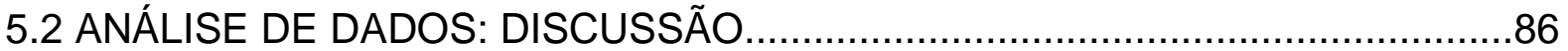

5.3 CONCLUSÕES: CARACTERÍSTICAS RELATIVAS ÀS INTERFACES A

SEREM CONSIDERADAS NO PROJETO ORGANIZACIONAL DO

TRABALHO 
6 PROPOSIÇÃO DE CONCEITOS E MÉTODO DE PROJETO ORGANIZACIONAL PARA PROCESSOS CONTÍNUOS....................................109

6.1 PROPOSIÇÕES CONCEITUAIS E METODOLÓGICAS..................................109

6.2 REVISÃO DOS CONCEITOS DE PROJETO...................................................111

6.2.1 Parâmetros Estruturais.........................................................................111

6.2.2 Mecanismos de Coordenação: um princípio que se junta aos conceitos

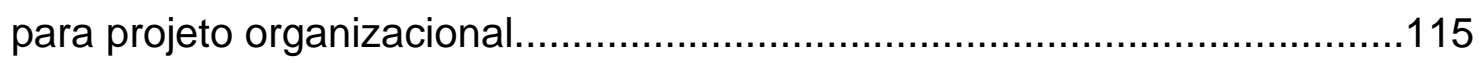

6.3 REVISÃO DAS REGRAS PARA PROJETO ORGANIZACIONAL....................119

6.4 COMPARAÇAO ENTRE A TEORIA EXISTENTE E AS PROPOSIÇÕES.........127

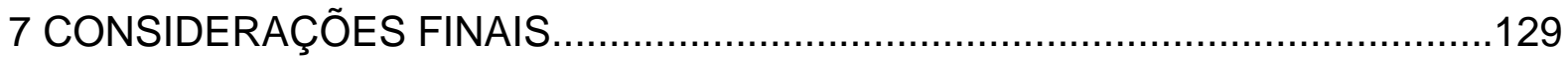

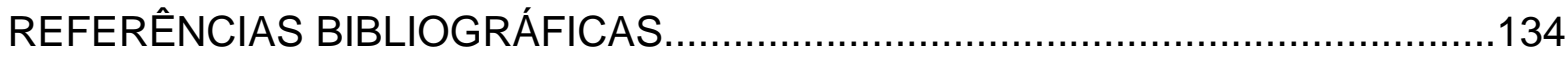

ANEXO 1 - ROTEIRO DAS ENTREVISTAS ...................................................139 


\section{INTRODUÇÃO}

A motivação para esta pesquisa tem dois aspectos, um prático e outro teórico. $\mathrm{O}$ aspecto prático vem da experiência do autor de cerca de vinte e cinco anos em sistemas de produção por processos contínuos. Nessa experiência, pôde constatar que um dos fatores primordiais para que o trabalho na produção nesse tipo de sistema seja bem sucedido depende da integração de diversas áreas, seja no dia-adia da produção, seja no atendimento a situações não previstas e indesejadas ou na implantação de projetos. Em todas essas situações existe forte interdependência das funções que intervém diretamente na produção, particularmente Operação, Manutenção e Engenharia, em razão da complexidade tecnológica e logística desse tipo de indústria.

No aspecto teórico, os estudos de organização do trabalho mostraram que a teoria de projeto organizacional do trabalho não aborda de modo apropriado a questão das interfaces entre as diferentes funções que atuam nos sistemas de produção contínuos. Há uma lacuna conceitual na teoria de projetos organizacionais.

Divisão do trabalho, critérios de segmentação para desenho da estrutura organizacional, estruturação dos segmentos e mecanismos de coordenação são abordados na literatura disponível sobre organização e projeto organizacional. Porém esses conceitos não são suficientes para o projeto de organização nos sistemas contínuos de produção. Nesses sistemas, a participação de funções como a Engenharia e a Manutenção nas atividades de operação é significativa (KHURANA, 1999; AULICINO, 1998). Essa participação acontece pela junção dos conhecimentos que esses domínios organizacionais (que correspondem organizacionalmente às funções) possuem aos da Operação, mediante atuação conjunta nos problemas do sistema de produção. Nessas ocasiões, as fronteiras organizacionais desses domínios deixam de ser rígidas, tornam-se fluidas e se movem criando intersecções. Ou seja, as fronteiras organizacionais se interpenetram, pois as funções atuam conjuntamente na execução e compartilham o controle do sistema de produção. 
Para melhor entendimento do que ocorre nas interfaces dos domínios organizacionais, é útil abordar o trabalho nos sistemas de produção. A automação de base eletrônico-digital, aliada a outros avanços tecnológicos, como novos materiais para uso mecânico, conferiu ao aparato técnico dos sistemas de produção velocidade e sofisticação bastante superiores ao que era anteriormente praticado. Duas exigências com respeito a esses sistemas de produção que ganharam destaque são confiabilidade dos equipamentos e sistemas, traduzida na realização das funções para as quais foram projetados, segundo os padrões especificados (MOUBRAY, 2000), e continuidade operacional, cujo significado é não haver interrupções da produção. Algumas das possíveis causas de interrupções da produção derivam de falhas dos equipamentos, falhas operacionais, de suprimento de matérias-primas, de programação de produção etc. Evidencia-se assim, o distanciamento da lógica clássica de produtividade, baseada na racionalização dos tempos e movimentos das tarefas executadas pelo homem. A nova lógica interna de desempenho dos sistemas de produção é baseada na velocidade das máquinas, na confiabilidade e na continuidade operacional do sistema técnico da produção. Do ponto de vista de exigências de mercado, estratégias competitivas, como preço, tempo, qualidade e inovação, impõem outros requisitos aos sistemas de produção, dentre eles custo, qualidade dos processos e flexibilidade. Em conseqüência dessa configuração técnica, dessa nova lógica de desempenho e dos requisitos desdobrados das estratégias competitivas, a operação dos sistemas de produção semelhantes aos que são aqui estudados assume um caráter tipicamente sistêmico (VELTZ e ZARIFIAN, 1993; BOLWIJN e KUMPE, 1990). No caso dos processos contínuos, que são o objeto deste estudo, a inter-relação entre os processos reforça esse caráter sistêmico (KHURANA, 1999).

Por causa dessas mudanças, o trabalho dos operadores voltou-se mais para o controle do desempenho do sistema de produção. Um exemplo dessa transformação que pode ser apresentado é referente à atividade de coleta de dados dos equipamentos e processos de transformação, observado em um dos casos estudados nesta pesquisa, a Refinaria Presidente Bernardes de Cubatão (RPBC), mas que certamente pode ser generalizado, ao menos para os sistemas de produção por processos contínuos. Há alguns anos, antes da informatização à distância, uma das atividades que consumia boa parte do tempo dos operadores das 
refinarias era coletar no campo dados dos equipamentos, como pressões, temperaturas e vazões. Todos esses dados eram lançados em planilhas para constituírem a base que serviria para analisar o desempenho dos equipamentos e dos processos. Também deviam prestar atenção, dentre outras coisas, ao aquecimento das máquinas, ruídos e temperaturas anormais. Atualmente, todos os dados relevantes do funcionamento dos equipamentos e dos processos podem ser adquiridos via instrumentação digital e informática e estarem disponíveis através das redes de computadores, não só para os operadores como para os profissionais de outras áreas. $\mathrm{O}$ controle dos processos e o acionamento dos equipamentos, antes feitos nos painéis existentes nas áreas de produção e no próprio campo agora podem ser centralizados em centros integrados de operação. Ao mesmo tempo em que a atividade de coleta manual deixou de ser realizada, a informatização e a automação permitem que os operadores trabalhem com um número maior de informações e controlem mais de uma unidade de produção ao mesmo tempo, ou seja, com uma atuação mais ampla. A atividade de verificação dos equipamentos no campo, identificando localmente possíveis anormalidades, continua a fazer parte da rotina de trabalho dos operadores. Só que agora grande parte das informações sobre as condições dos equipamentos, como nível de vibração e temperaturas dos equipamentos mais críticos e de etapas dos processos, aparecem nas telas de controle dos Sistemas Digitais de Controle Distribuídos (SDCD).

Por outro lado, a lógica demonstrada vem acompanhada de aumento da complexidade tecnológica, do uso de equipamentos mais sofisticados e do aumento da quantidade de informações disponíveis para a otimização do desempenho dos processos. Em razão da complexidade, as habilidades e conhecimentos necessários à operação dos sistemas de produção vão, muitas vezes, além daqueles detidos pelos operadores, o que torna bem presentes no dia-a-dia da produção outras funções, especialmente a Engenharia e a Manutenção, detentores de outras habilidades e conhecimentos (KHURANA, 1999). Em conseqüência, nos procedimentos de operação há uma forte participação dos profissionais da manutenção e da engenharia da fábrica, que determinam à produção parâmetros de controle do processo, resolvem problemas de grande complexidade tecnológica e logística e modificam os processos e equipamentos para obter melhores resultados e precisam interagir com a Operação, tendo em conta os saberes que esta acumula. 
Assim, constata-se outro fator importante na lógica de desempenho em sistemas de produção modernos, decorrente do seu caráter sistêmico: as interfaces internas. Vários autores consideram que, em sistemas integrados e complexos, a eficiência depende mais da qualidade das interfaces do que da racionalização das atividades em cada função em si (VELTZ, 2000; WORLEY e LAWLER III, 2006; GRATTON et al., 2007).

Por exemplo: como interagem as funções Manutenção e Operação no sentido de garantir a confiabilidade de determinada unidade de produção? Ou, tomando-se o caso dos controles avançados de processo, cada vez mais empregados nas indústrias de processamento contínuo: como interagem a Operação, a Engenharia e a Manutenção para que os modelos matemáticos de controle representem de modo adequado a realidade das operações, que os instrumentos utilizados tenham o nível de desempenho necessário, que os operadores saibam incorporar corretamente os aparatos automatizados e informatizados de controle ao seu trabalho de regulação do processo de produção e que realimentem os engenheiros de automação e de processos com as informações corretas do desempenho dos aparatos instalados? $\mathrm{O}$ projeto organizacional deve prever formas de compartilhar a responsabilidade da operação dos processos de produção entre os engenheiros de automação, que detém o conhecimento especializado de construção de modelos matemáticos, os operadores, que possuem o saber do funcionamento real dos sistemas operacionais, os instrumentistas e eletricistas, que monitoram o desempenho dos instrumentos e equipamentos de controle (KHURANA, 1999; SHOOK, 2006).

Ao longo do período de atuação profissional deste autor em sistemas de produção por processos contínuos, na siderurgia e no refino de petróleo, várias situações foram observadas ou vivenciadas envolvendo a atuação conjunta dos três domínios tratados, uma delas é o exemplo acima da automação do controle dos processos. $\mathrm{Na}$ posição de observador-ator foi despertada a atenção para o problema da organização do trabalho nas interfaces internas do sistema de produção, particularmente nos sistemas contínuos, onde o trabalho é coletivo e complexo, envolvendo profissionais de diferentes domínios de atuação. Entende-se aqui por coletivo e complexo, não apenas o trabalho dos operadores da produção, conforme descrito por Ferreira e Iguti (1996), mas o fato das intervenções no processo e nos 
equipamentos envolverem também profissionais de Manutenção e Engenharia, com interdependência entre as ações e decisões desses segmentos.

Tome-se o caso da detecção de defeito em um equipamento (o conceito de defeito é uma mudança no estado de um equipamento, como o desgaste ou quebra de um componente, que pode alterar de modo indesejado as suas condições de funcionamento). A identificação da situação pode ser do operador, no seu trabalho de monitoramento dos processos ou do profissional de manutenção ao analisar dados de funcionamento do equipamento. O passo seguinte de identificação das conseqüências do defeito - as falhas possíveis - envolve aspectos do processo de produção como desvios de qualidade de produtos, dificuldades de controle das variáveis dos processos, vazamentos de produtos, que podem significar riscos às instalações e às pessoas, impactos ao meio-ambiente, perda de produção etc. No aspecto da integridade do equipamento, que danos o defeito detectado pode causar ao próprio equipamento ou a outros equipamentos ligados a ele e que conseqüências podem ter esses danos?

O resultado dessas análises é a decisão de parar ou não o equipamento para reparo. Como uma refinaria de petróleo, uma fábrica petroquímica ou uma usina siderúrgica, dentre outros sistemas de produção contínua, usualmente são conjuntos de plantas ou fábricas onde os produtos de uma são as matérias-primas de outras, a interrupção do funcionamento de um equipamento pode implicar na perda de produção na planta em que ele se localiza ou de mais de uma planta, conforme o fluxo de produção, existência de estoques intermediários etc. Outras informações impactam essa decisão: existe equipamento reserva? Ele está disponível para operar? Ele foi testado? Se o equipamento reserva estiver em manutenção, quando será concluída? O equipamento defeituoso pode esperar? Existe algum modo de operar a planta, mesmo havendo perda de eficiência, com esse equipamento parado? Quanto tempo levaria para ser feito o reparo do equipamento defeituoso? Quais as conseqüências da interrupção de produção?

Toda essa análise envolve profissionais da Operação e da Manutenção, com seus conhecimentos dos equipamentos e das operações de fabricação, e da Engenharia, tanto para avaliação das condições dos equipamentos e conseqüências dos defeitos, como para avaliação das implicações nos processos de transformação, 
pois a análise pode requerer conhecimentos e habilidades de domínio dos engenheiros.

Caso decida-se pela interrupção da produção para reparo do equipamento, surgem outras situações de interface. Pode ser necessário esgotar-se o equipamento, descontaminá-lo, garantir que esteja isento de gases residuais tóxicos ou explosivos e isolar o equipamento do restante da planta. Essa ação pode ter que se estender a outros equipamentos ligados àquele sob intervenção. Só então a Manutenção pode atuar diretamente sobre o equipamento defeituoso. É necessário um bom planejamento, integrando a Operação e a Manutenção para que a intervenção seja feita de modo a sanar o problema e minimizar a perda de produção. E para que o problema seja sanado, é necessário chegar-se às suas causas, análise essa que pode necessitar, mais uma vez, dos conhecimentos e habilidades da Engenharia.

$\mathrm{Na}$ Dissertação de Mestrado, que estudou a organização do trabalho nas equipes de operadores da Refinaria Presidente Bernardes - Cubatão, este autor descreveu algumas situações decorrentes da interface entre operadores e engenheiros:

O segundo conflito diz respeito ao controle da operação do processo de produção que, como mostrado acima, possui dois ciclos de controle distintos, mas não independentes, exercidos pelos operadores e pelos engenheiros de processo, com o poder decisório das gerências de produção (chefias de setores) podendo interferir em ambos os ciclos de controle (AULICINO, 1998, p. 159).

Um dos ciclos de controle a que se refere o parágrafo acima é o controle operacional das variáveis do processo de produção, ou seja, das transformações físico-químicas das matérias-primas, de acordo com parâmetros especificados, exercido pelos operadores. Dessa forma, para um processo como o de refino de petróleo, não há separação entre executar o processo e controlá-lo, ao menos no curto prazo. O outro ciclo de controle é aquele realizado pelos engenheiros de processo, através da análise freqüente dos dados desse processo, da eficiência dos equipamentos, características dos produtos, atendimento a requisitos de mercado etc. Esse controle pode ser considerado em um nível mais tático, e a interferência no processo de produção se dá por meio da proposição de melhorias e correções do processo. Uma das formas de conflito que pode ocorrer é a discordância pela Operação das proposições e recomendações da Engenharia, tanto para melhorias como para correções do processo. 
Do ponto de vista das interfaces externas do sistema de produção, podem ser citadas as interferências de mercado, as restrições legais e regulatórias, as questões socioambientais, os requisitos de desempenho econômico-financeiro, variações no abastecimento de matéria-prima, dentre outras. Todas essas interferências vão exigir ajustes ou modificações dos processos, e até dos equipamentos, demandando ações da Operação, da Engenharia e da Manutenção.

As empresas onde o trabalho de operar os sistemas de produção tem características descritas acima, isto é, onde as interfaces entre Operação, Engenharia e Manutenção têm papel fundamental no seu desempenho, organizam o trabalho nessas interfaces com maior ou menor eficiência. Uma pergunta pertinente é se existem conceitos e métodos na literatura que possam ser utilizados para elaborar um bom projeto organizacional, que considere interfaces com fronteiras móveis e que se interpenetram, de forma a tornar melhor o desempenho desses sistemas.

O referencial teórico para a organização das interfaces entre Operação, Manutenção e Engenharia pode ser buscado na teoria de projeto organizacional. Uma abordagem apropriada para o projeto organizacional do trabalho, que envolve aspectos técnicos e sociais, é a sociotécnica moderna.

Ela apresenta desenvolvimentos da teoria organizacional que se seguiram à aplicação dos princípios da sociotécnica clássica, oriundos do Instituto Tavistock, e que representaram um movimento em direção a uma teoria e prática de projeto organizacional na década de 90 . Os conceitos e métodos foram desenvolvidos e utilizados em trabalhos como os realizados na Holanda por pesquisadores como Sitter; Dankbaar e Hertog (1994, 1997); Zwaan (1975, 1994); Eijnatten e Zwaan (1998) e no Brasil por Salerno (1995, 1999, 2007); Marx (1997) e Aulicino (1998).

Sitter; Dankbaar e Hertog $(1994,1997)$ desenvolveram uma metodologia de projeto organizacional para o trabalho na produção, abordando princípios e estratégias de projeto. Aulicino (1998) estudou a aplicação desses conceitos ao projeto do trabalho em equipes de operadores de refinarias de petróleo. Marx (1997) tratou da questão da autonomia nas equipes de trabalhadores, que são a unidade organizacional básica da sociotécnica para a estrutura de execução da produção. Salerno (1999) propôs a criação de espaços de comunicação-negociação, fazendo avançar a teoria de projeto organizacional com base, dentre outros, nos conceitos apresentados acima, focando principalmente o que chama de "atuação vertical do operariado" 
(com relação aos sistemas de apoio e de gestão). Os estudos e proposições de Aulicino (1998) e de Salerno (1999) têm influência, dentre outros, do trabalho de Zarifian (ZARIFIAN, 1990; VELTZ e ZARIFIAN, 1993; ZARIFIAN e AUBÉ, 1992), que propõe um novo papel para os operários, usando o aprendizado dos eventos da produção, os conhecimentos desses trabalhadores e comunicação entre diferentes categorias profissionais.

O objetivo desta pesquisa, portanto, é propor contribuições à teoria de projeto de organização, no âmbito da Sociotecnologia Moderna, para tratar as situações em que a Engenharia participa ativamente do trabalho da Operação e da Manutenção, e estas duas têm interligações importantes, por uma necessidade inerente à complexidade técnica dos sistemas de produção. A razão principal sob o ponto de vista teórico é que, embora a questão das interfaces dos grupos de trabalhadores da produção seja abordada na teoria de projeto de organização do trabalho disponível, essa abordagem é no sentido de como os grupos de operadores se organizam e como ocorre a participação dos trabalhadores em questões consideradas pertinentes às suas atividades, mesmo no que diz respeito à "comunicação com outras categorias profissionais", empregando aqui o mesmo termo utilizado por Veltz e Zarifian (1993). Constata-se uma lacuna na teoria de projeto organizacional: os parâmetros, estratégias e regras de projeto não incluem o projeto de interfaces nas quais as fronteiras entre as funções que atuam diretamente na operação do sistema de produção se movem para que executem atividades conjuntamente e compartilhem o controle sobre fatores do desempenho desse sistema.

Neste trabalho serão tratadas as interfaces internas do sistema de produção, se concentrando naquelas existentes entre as funções Operação, Engenharia e Manutenção. Conforme as observações realizadas, essas são as funções mais atuantes no sistema de produção. Isso não significa ignorar as interferências externas. Apenas o seu tratamento não será objeto de análise no contexto da pesquisa, sem deixar de considerar os impactos do meio externo no sistema de produção.

Uma segunda delimitação para exploração do tema é a concentração da pesquisa em organizações industriais de processamento contínuo. O primeiro motivo é o fato das intervenções da Engenharia e da Manutenção na produção serem mais usuais e significativas nos sistemas contínuos de produção. Khurana (1999) ao fazer essa 
afirmação, justifica que quanto maior a complexidade dos sistemas de produção, maior é a necessidade de intervenção de outros profissionais que não os da Operação no funcionamento dos sistemas, a fim de aportar conhecimentos e habilidades técnicas. E dentre os sistemas de produção, constatou que os contínuos são os que apresentam maior complexidade, ressaltando os aspectos de complexidade tecnológica e de fluxos.

O segundo motivo do foco nos processos contínuos é a vivência do autor em siderurgia e refino de petróleo. Foi essa vivência que permitiu identificar a importância do trabalho integrado da Operação, Engenharia e Manutenção para o desempenho dos sistemas de produção contínuos, ao experimentar e presenciar situações de sucesso e problemas decorrentes de boa e de má integração organizacional dessas funções.

A situação de empregado da Petrobras enseja melhores oportunidades de acesso aos dados e às pessoas que trabalham em refinarias de petróleo, que são casos clássicos de processos contínuos. Atende também ao interesse da própria empresa em promover o estudo e a pesquisa acadêmicos de temas ligados às suas atividades pelos profissionais de seu quadro.

Trata-se, ainda, de uma ampliação da abrangência da pesquisa realizada na dissertação de mestrado do autor, onde o tema era a organização do trabalho dos grupos de operadores de refinarias de petróleo, realizada na Refinaria Presidente Bernardes - Cubatão. Na presente pesquisa, o tema amplia-se para considerar a participação de outras funções no trabalho de operar os sistemas de produção contínuos.

Desse modo, se junta um problema prático, o comprometimento do desempenho do sistema de produção se não houver boa integração - interfaces bem projetadas e mecanismos de coordenação - entre as funções que atuam na produção a uma lacuna conceitual: o não tratamento adequado de interfaces desse tipo - móveis e interpenetrantes - na teoria de projeto organizacional sociotécnica moderna.

A tese está estruturada da seguinte forma: inicialmente, no Capítulo 2, é feito um apanhado da teoria de projeto organizacional sociotécnica moderna, que serve de referência para a pesquisa; o Capítulo 3 traz a metodologia de pesquisa adotada; no Capítulo 4 são apresentados os casos estudados, que são da RPBC e de indústria 
de Fertilizantes; os dados colhidos na pesquisa são analisados no Capítulo 5; as discussões e proposições teóricas - alterações e complementos à teoria de projeto organizacional - aparecem no Capítulo 6; finalmente, no Capítulo 7 estão as considerações finais. 


\section{QUADRO CONCEITUAL}

\subsection{OS SISTEMAS DE PRODUÇÃO POR PROCESSOS CONTÍNUOS}

Pode-se dizer que os processos contínuos são aqueles em que o carregamento de matéria-prima, a sua transformação e a saída de produtos, em um dado sistema, não sofrem interrupção ao longo do tempo (AULICINO, 1998, SALERNO, 1991; FERRO et al., 1987).

Os sistemas contínuos são usados para produzir grandes volumes de um único item ou relativamente poucos itens, com elevado grau de padronização, usando equipamentos especializados. Dessa forma, é problemático modificar tanto a linha de produtos como o volume de produção (função dos equipamentos e não da mãode-obra), o que leva à inflexibilidade desses sistemas (WOODWARD, 1977; AULICINO, 1998).

Valendo-se de outro tipo de classificação dos processos de produção, Salerno (1991) classifica os casos de refino de petróleo, química, petroquímica, cimento, sucro-alcooleira, que são freqüentemente processos contínuos de fabricação, dentre os processos de propriedade (a outra forma de processos de propriedade seria produção por batelada), ou seja, onde não importa a forma dos produtos mas as propriedades características que ele deve possuir, obtidas através de transformações físico-químicas. Neste trabalho, os processos de produção analisados serão denominados contínuos, sem esquecer a condição de processos de propriedade.

Por necessitarem de tecnologias complexas e requererem grandes investimentos de capital, as indústrias de processo contínuo são dominadas por grandes empresas. Também fisicamente as instalações são de grande porte. Em conseqüência, uma característica marcante é a descentralização física, expressa pela distribuição de diferentes unidades de uma mesma companhia e pelo próprio arranjo-físico das plantas. As operações de fabricação são realizadas em diferentes edifícios e plantas, 
também chamadas de unidades operacionais, de produção ou de processo, com largos espaços livres entre eles. Assim, uma fábrica química ou de refino de petróleo é na realidade um conjunto de unidades (cada unidade contendo um conjunto de equipamentos) em cada qual certos tipos de reações ou processos diferentes ocorrem, ou diferentes produtos e subprodutos são processados, sendo muitas vezes os produtos de uma planta a matéria-prima de outras plantas.

Algumas características tecnológicas que predominam nas indústrias que operam por processos contínuos (FERRO et al., 1987):

- Processo de produção com alto grau de integração, devido às operações serem parte de um sistema ininterrupto;

- Dificuldade de se distinguir matérias-primas e insumos após terem sido carregados no processo produtivo;

- Baixa flexibilidade quando comparadas às indústrias de manufatura, como as de máquinas-ferramentas;

- Seqüências de atividades mecanizadas cada vez maiores e mais complexas;

- Utilização cada vez maior de sistemas de instrumentação de autocorreção de peso, volume, taxa de fluxo, temperatura, pressão, características químicas etc. Observa-se atualmente, a utilização crescente de malhas de controle automatizadas para essa regulação do processo;

- Tendência cada vez maior de separação das máquinas do seu ponto de controle, possibilitando a centralização das estações de controle;

- Desconexão entre ritmo de trabalho e ritmo de produção, uma vez que o trabalho fundamental dos operadores é de monitoração e controle do processo de transformação das matérias-primas e insumos em produtos intermediários e finais. Em conseqüência, a produtividade depende muito mais da taxa de uso global das instalações do que do ritmo de trabalho dos operadores;

- Utilização crescente da informática em atividades externas à operação do sistema, propriamente dita, como as de controle e movimentação de estoques e de engenharia. 
Woodward (1977), em pesquisa que compara diferentes tipos de tecnologia de produção com a organização das empresas e sucesso empresarial, conclui que as empresas que produzem através de processos contínuos têm organização mais flexível, com tendência a se adotar sistemas orgânicos de administração.

Um estudo realizado (INOMATA et al., 1997) faz uma projeção do ambiente e das características das refinarias de petróleo. Embora seja um estudo específico sobre a indústria de refino de petróleo, as exigências consideradas no estudo certamente dizem respeito a outros ramos de atividades industriais: mínima emissão de resíduos para a atmosfera, produtos limpos, segurança nas operações, qualidade do ambiente de trabalho. Esta última exigência inclui não só facilidades físicas, como um centro de produção com avançada tecnologia de informação, como fatores ligados à satisfação pessoal dos empregados e o desenvolvimento da comunicação com as comunidades locais. Essas características estão presentes nos casos estudados nesta pesquisa.

\subsubsection{A Operação nos Processos Contínuos}

Usualmente a operação dos sistemas de produção contínua é feita por grupos de operadores que trabalham em regime de turno, com cada um desses grupos respondendo pela operação de uma ou mais unidades de produção. O trabalho dos operadores pode ser dividido em trabalho em painel e trabalho de campo.

Como praticamente todo o processamento e manuseio de matérias-primas são feitos de forma mecanizada, com controles mecanizados, o trabalho do operador é monitorar esse processo e a qualidade dos produtos através da observação de painéis de controle, telas de computador, observação dos equipamentos, verificação dos instrumentos de medição e por análises físicas e químicas, efetuando a regulação dos processos quando necessário. A regulação ocorre através de ajuste dos pontos de controle de instrumentos e de manobras operacionais de mudanças de fluxos internos aos processos, substituição de equipamentos, mudanças de 
matérias-primas etc. Usualmente esses pontos de controle e os procedimentos para as manobras operacionais são definidos em sistemas de padrões documentados (AULICINO, 1998; KHURANA, 1999).

A atividade freqüente do operador de painel (esse nome vem da época anterior à informatização, quando o operador observava painéis com mostradores, onde podia ler as variáveis principais do processo) é o monitoramento, através da atenção às telas de computador onde são mostradas as variáveis dos processos, e do atendimento aos alarmes que soam quando esses parâmetros saem dos limites préestabelecidos. Essa vigilância é exercida em função da imagem que ele faz do processo em um dado instante, tendo como base os modelos mentais desenvolvidos através do conhecimento e experiência, e das informações sobre a situação dos processos e instalações obtidas em procedimentos escritos, instruções operacionais, resultados de análises de laboratório e interações com os colegas de campo, de outras unidades, supervisor e coordenador de turno. As necessidades de intervenção no processo para sua regulagem são percebidas através desse monitoramento (DANIELLOU, 1986; DUARTE, 1994; BOUYER e SZNELVAR, 2005).

Atualmente, parte desse trabalho de regulagem dos processos é realizada de forma automatizada pelos sistemas de controle avançado, que continuamente recebem as mesmas informações sobre as variáveis dos processos e implementam correções, segundo um algoritmo estabelecido. Entretanto, variações dos processos não previstas pelos modelos matemáticos ou que extrapolem sua capacidade de resposta continuam exigindo a intervenção direta do operador de painel.

O trabalho rotineiro dos operadores de campo também tem características de monitoramento ou de vigilância. Consiste na verificação local do funcionamento dos equipamentos e de situações do processo, incluindo a leitura de instrumentos instalados no campo e coleta de amostras de insumos e produtos para análises locais, efetuadas pelos próprios operadores, ou em laboratório, efetuadas por técnicos de laboratório. A constatação de situações não desejadas pode levar a intervenções, como retirada de funcionamento de equipamentos, que se constate estejam trabalhando fora de suas condições normais, com o concomitante acionamento de equipamentos reservas, à procura de uma nova situação segura de ajuste do processo ou o acionamento do pessoal da manutenção para realizar 
avaliações técnicas da condição de equipamentos e realizar intervenções necessárias.

Faz parte também do trabalho diário dos operadores de campo a colocação rotineira de equipamentos reserva em operação, a preparação e entrega de equipamentos para os trabalhos de manutenção ou para a execução de projetos de modificações das instalações e o recebimento dos equipamentos e colocação em operação ao término dessas intervenções.

Para realização desses trabalhos de campo os operadores se dividem segundo lógicas de sistemas operacionais e de tipos de atividades. Os sistemas operacionais são representados por conjuntos de equipamentos que desempenham partes dos processos que acontecem em uma unidade. Por exemplo, o sistema de obtenção de determinado produto, o sistema de tratamento desse produto e o sistema de água de resfriamento dos equipamentos. Paralelamente, um ou mais operadores podem ficar encarregados da atividade de atender o pessoal da manutenção que realiza serviços naquela unidade, fazendo a liberação dos trabalhos de manutenção com o conhecimento e a participação do operador encarregado do sistema operacional onde está o equipamento e do operador de painel. Nesse aspecto, podem existir operadores alocados em horário administrativo para atender às necessidades de manutenção, já que nesse horário são realizadas as manutenções programadas, ocasionando um pico de trabalho.

Outro aspecto do trabalho de operação é a constante interação entre os operadores de um grupo. O operador de painel está constantemente se comunicando com os operadores de campo, recebendo ou solicitando informações, como a verificação local da condição de um equipamento, a confirmação da leitura de uma variável, que por falha de instrumento pode não estar apresentando seu valor real. Também entre os operadores de campo ocorrem interações, como a do operador que atende a manutenção com o operador que está atuando em certa área onde os trabalhos de manutenção são efetuados. Ou, ainda entre os operadores que estão alocados em áreas diferentes da unidade operacional, quando constatam alguma situação que pode ser decorrente do que acontece em outra área, ou vice-versa.

A comunicação entre os trabalhadores inclui não apenas a troca de informações sobre as situações constatadas no processo de produção, mas também a sua interpretação, visando adoção de medidas que possibilitem a continuidade da 
operação de modo seguro e confiável. Forma-se, assim, uma espécie de modelo mental coletivo, onde o conhecimento e a experiência dos diferentes operadores do grupo, resultante da formação e da vivência de outras situações, são compartilhados e sobre o qual se definem as ações que o grupo irá tomar para o controle dos processos de produção (DUARTE, 1994; FERREIRA e IGUTI, 1996 e AUCILINO, 1998).

\subsubsection{A Função Manutenção na Produção por Processos Contínuos}

Para que o sistema de produção cumpra seus objetivos é necessário que as instalações mantenham-se capazes de cumprir as funções para as quais foram projetadas. Essa necessidade exige a ação não só dos operadores da produção, mas de profissionais especializados no controle das condições dos equipamentos, no reparo e na restauração das condições desses equipamentos (MOUBRAY, 2000; NAGAO, 1998). Nagao (1998) define a Manutenção como a "função estratégica que busca a disponibilidade e confiabilidade das instalações através da diminuição de quebras e falhas nos equipamentos e sistemas, otimizando o uso dos recursos disponíveis".

Exemplificando, da observação de eventos em refinarias de petróleo e em usinas siderúrgicas, a constatação de que uma vazão está aquém da desejada pode significar um erro do instrumento de medição, uma válvula que não abre o suficiente para permitir aquela vazão ou uma bomba ou compressor defeituosos. Ou seja, algum dispositivo não está cumprindo a função para a qual foi projetado. A equipe de operadores da planta passa a procurar a causa da falha, a adotar medidas para manter a vazão dentro de parâmetros aceitáveis e acionar o pessoal necessário para reparar a causa da falha. No caso de necessidade de especialistas para sanar o problema, entra em cena a Manutenção, fazendo nesse caso uma intervenção corretiva. 
A intervenção da Manutenção terá sucesso na medida em que ela for acionada no tempo certo e que tiver as informações adequadas sobre o equipamento e sobre a falha para poder identificar suas causas e fazer o reparo nas melhores condições de eficiência e eficácia ${ }^{1}$. Além disso, a manutenção só poderá intervir no equipamento após a Produção oferecer as condições para isso, como esvaziar os fluidos do sistema e garantir que não haverá qualquer resíduo nos equipamentos, se eles contiverem material tóxico, explosivo, inflamável, corrosivo etc.

A manutenção preventiva, por sua vez, pode acontecer quando o período em que ocorrem as falhas dos equipamentos é conhecido. Isso possibilita a intervenção nos equipamentos a intervalos programados, prevenindo-se a ocorrência de falhas e evitando as situações descritas acima. Normalmente os programas de intervenções devem considerar tanto a periodicidade esperada das falhas como as necessidades de disponibilidade dos sistemas de produção, para que seja possível a liberação dos equipamentos para o trabalho de manutenção.

A predição da falha permite que aqueles que gerenciam os sistemas de produção e os operadores da Produção tomem as medidas necessárias à continuidade operacional ou à minimização dos efeitos de uma parada do sistema de produção ou de parte dele, antes da ocorrência da falha. Para o pessoal da Manutenção, a predição da falha possibilita o planejamento da intervenção, incluindo a análise das causas da falha, preparação de material, de pessoal etc, resultando em maior chance de êxito, ou seja, que as causas da falha sejam corrigidas com um menor tempo de intervenção. Os resultados desse tipo de intervenção são a minimização das perdas de produção e evitar danos ao ambiente, às pessoas e às instalações, que podem ocorrer em eventos não previstos (MOUBRAY, 2000).

Para a detecção do desencadeamento de processos de falha é necessário o monitoramento de parâmetros de funcionamento dos equipamentos, como temperatura, níveis de vibração, presença de contaminantes e propriedades químicas no óleo lubrificante. A alteração desses parâmetros fornece informações para que os especialistas da Manutenção façam projeções da ocorrência de falhas.

\footnotetext{
MOLINARI, R.; SOUZA, GILBERTO F. M. Notas de aula da disciplina Fundamentos de Manutenção de Sistemas Mecânicos. Departamento de Engenharia Mecatrônica, Escola Politécnica, Universidade de São Paulo, 2004.
} 
Entretanto, outras alterações de condições dos equipamentos, como ruídos e mudanças nos valores de pressões indicam aos operadores experientes que uma condição anormal está ocorrendo.

Uma evolução desses conceitos de manutenção, principalmente o de manutenção preditiva, é a manutenção centrada em confiabilidade, conhecida pela sigla RCM (Reliability Centered Maintenance). A RCM prega a ação pró ativa, ou seja, a intervenção antes da ocorrência da falha, se essa intervenção reduzir os riscos ao meio-ambiente e à segurança, decorrentes da falha a valores baixos e toleráveis ou se as conseqüências da falha, que são os custos da perda de produção e do reparo, forem maiores que da tarefa pró ativa (MOUBRAY, 2000). Essa tarefa pró ativa não se resume ao serviço de manutenção, pode ser uma alteração no modo de operar os equipamentos. Um exemplo que foi visto na RPBC, foi a detecção de vibração excessiva em bombas em razão de cavitação durante a partida do equipamento. Uma ação operacional possível é a restrição do fluxo pela bomba, que ocasiona redução da cavitação e, em conseqüência, da vibração, que possivelmente levaria a uma quebra na bomba.

Caso não sejam encontradas tarefas pró ativas que reduzam o risco de falha, se elas forem associadas ao meio ambiente ou à segurança, ou ainda se o custo da ação pró ativa for muito alto, então a decisão deve ser de reprojetar o equipamento ou o sistema (MOUBRAY, 2000). Nessas situações pode ser necessário acionar outra função: a Engenharia.

\subsubsection{A Atuação da Engenharia nos Processos Contínuos de Produção}

Conforme foi observado na RPBC, as principais atividades da Engenharia junto ao sistema de produção são: definição de parâmetros de controle do processo de produção visando à otimização do sistema produtivo, alteração desses parâmetros para atender mudanças nas especificações desejadas para os produtos, análise do desempenho e solução de problemas em equipamentos de produção, elaboração de 
projetos de modificação nas instalações para melhorar a eficiência dos processos, para atender novas especificações de produtos ou para corrigir problemas de operação, e a engenharia de manutenção, que estuda as intervenções necessárias nos equipamentos e a sua manutenibilidade. Ainda se incluem os projetos, acompanhamento técnico da fabricação e montagem de novas plantas e de sua préoperação.

Verifica-se uma participação bastante forte da Engenharia no controle dos processos de fabricação, onde os estudos técnicos dos engenheiros de processos definem os parâmetros das variáveis do processo produtivo sobre os quais será exercido o controle, que constitui a essência da atividade operacional da Produção. Essa definição de parâmetros das variáveis dos processos de fabricação tradicionalmente é comunicada através de documentos: pareceres técnicos e recomendações de engenharia ou documentos da Produção, como manuais de operação e padrões de processo.

Consoante o sistema técnico da produção contínua, de forte automação, boa parte das intervenções da Engenharia na operação do sistema de produção se faz pelo projeto e instalação de sistemas computadorizados de controle de processos. Nesses sistemas, modelos matemáticos instalados em computadores, também chamados de controle avançado, recebem os valores das variáveis do processo de produção diretamente do Sistema Digital de Controle Distribuído, calculam e informam ao próprio sistema digital os valores dos parâmetros para manter os processos sob controle. Por exemplo, a informação de certo valor de pressão ou de temperatura leva o algoritmo a informar ao SDCD um valor de abertura da válvula de controle, que é transferido ao seu atuador para manter aquelas variáveis dentro da faixa de valores especificada.

Ao longo do tempo pode ser necessário alterar a especificação de um produto, em razão de necessidades de mercado ou de mudanças em requisitos legais, que impõem especificações aos combustíveis, por exemplo. Usualmente, nas indústrias de processos, a especificação de um produto é determinada pelas suas características físicas e químicas, como a resistência mecânica de um aço, a densidade de um combustível ou a faixa de temperaturas de início e fim de vaporização de um solvente. Essas alterações podem levar à fixação de novos parâmetros de controle do processo, podendo também exigir mudanças de matérias- 
primas para obtenção das características especificadas para os produtos. Para se chegar aos novos parâmetros são necessários estudos da Engenharia e, em muitos casos, a realização de testes nos processos e nos produtos, conduzidos pela Engenharia e pela Produção. É interessante lembrar que, devido às características dos processos contínuos, de equipamentos dedicados e de grande porte, normalmente esses testes são feitos em condições reais no próprio sistema de produção. Uma vez estabelecidos os novos parâmetros de controle do processo de produção, procede-se à alteração da documentação técnica - padrões de processo, manuais de operação etc, e a alteração dos algoritmos de controle computadorizado.

Outra atividade permanente da Engenharia é a busca da otimização dos processos de produção. O refino de petróleo constitui-se em um conjunto de processos de transformação da matéria-prima em produtos finais para venda aos consumidores e em produtos intermediários. Estes precisam de novas, e às vezes sucessivas, transformações para se tornarem produtos finais, ou seja, nas formas e especificações que o mercado os utilizam. A otimização desses processos pode ocorrer pela redução do consumo de energia, pela redução de insumos de processos, como catalisadores e outros produtos químicos, pela utilização de insumos de menor custo, pelo aumento da taxa de transformação desejada com uma dada reação, pela obtenção de quantidades maiores ou menores de um dado produto em função das condições de mercado, dentre outros modos. Todos esses modos implicam em alterações dos pontos de controle das variáveis dos processos.

A Engenharia participa da resolução de problemas complexos do sistema de produção, sejam eles de controle do processo de produção ou de confiabilidade e de disponibilidade dos equipamentos, como já foi visto nos itens que trataram da Produção e da Manutenção.

Tomando-se diversas definições existentes na literatura para a função Engenharia (NAKANO, 1997; PLONSKI, 1986; KAPLINSKY, 1984) e as atividades desempenhadas no caso estudado, pode-se concluir que o papel da Engenharia na produção por processos contínuos é aplicar conhecimentos tecnológicos, através de estudos e projetos, para a resolução de problemas, para o aperfeiçoamento dos processos de produção e dos equipamentos através dos quais esses processos ocorrem, para alterar os processos e equipamentos com o fim de fabricar novos 
produtos ou mudar características de produtos existentes, contribuindo para a gestão do sistema de produção.

\subsection{CONCEITOS E MÉTODOS PARA PROJETO DE ORGANIZAÇÃO DO TRABALHO}

Embora bastante vasta, a teoria organizacional em grande parte tem uma abordagem analítico-descritiva da organização, quer dizer, faz análises, apresenta modelos analíticos e conceitos, mas pouco trata de métodos e regras para a realização de projetos organizacionais. Nesse universo, uma abordagem que se diferencia é a teoria sociotécnica moderna, por ser voltada para o projeto organizacional (EIJNATTEN e ZWAAN, 1998), o que a torna significativa como referencial teórico para a presente pesquisa.

As abordagens de projeto organizacional são apresentadas pelos autores da linha sociotécnica moderna na forma de conceitos, princípios e regras de elaboração de projetos. No dizer desses autores, em especial os holandeses Sitter; Hertog e Dankbaar (1994, 1997), que sintetizam bem a linha holandesa de projeto sociotécnico, e Salerno (1999, 2007) no Brasil, o projeto organizacional deve ter como objetivo dotar a organização da capacidade de lidar de forma simples com as variações dos sistemas de produção existentes hoje em dia.

É oportuno esclarecer que para esses autores, a complexidade organizacional dos sistemas é relativa ao seu número de unidades organizacionais (departamentos, seções, grupos etc.), ao número de relações externas e internas e à ocorrência de variações ao longo do tempo. Assim, as metodologias de projeto que eles apresentam através da arquitetura da estrutura organizacional, buscam desenvolver e reforçar relações para reduzir o impacto de variações no sistema com respeito a requisitos como flexibilidade, tempo de entrega, controle ambiental, qualidade de produto, qualidade no trabalho etc., além de eventos relativos à própria instabilidade do processo de transformação em si (problemas em equipamentos, variações de 
qualidade de matéria-prima etc.). Buscam ainda, aumentar a capacidade de gerenciar aquelas variações cuja incidência sobre os diferentes aspectos do sistema de produção não se possa reduzir.

Os pesquisadores holandeses denominam de controlabilidade a capacidade da organização de gerenciar variações, que deve ser genérica, decorrente do projeto organizacional, e não especifica para determinados problemas. Alguns autores chamaram essa capacidade de dirigibilidade (SALERNO, 1999; AULICINO, 1998), numa correspondência ao termo francês pilotage (ZARIFIAN e AUBÉ, 1992; VELTZ e ZARIFIAN, 1993).

As abordagens para projeto adotadas pelos autores citados, porém, apresentam algumas diferenças entre si. Sitter; Dankbaar e Hertog $(1994,1997)$ abordam o projeto sob o enfoque estrutural. Pelo desenho da arquitetura das estruturas de produção e de controle, onde determinam as fronteiras das unidades que compõem a estrutura organizacional, visam reduzir variações que possam perturbar o funcionamento do sistema de produção e aumentar a capacidade de promover variações desejadas. Salerno $(1999,2007)$ parte do método para projeto desses autores e sua contribuição é a inclusão na teoria de projeto organizacional de aspectos de comunicação, com destaque para a criação de espaços comunicacionais para a coordenação de elementos organizacionais (equipes, grupos, setores, departamentos etc.) e introduz a noção de evento como nucleador da divisão do trabalho. Percebe-se na sua proposta a influência da organização qualificante (ZARIFIAN e AUBÉ, 1992). Procura inserir na metodologia de projeto organizacional, com essa abordagem, o tratamento da dinâmica da organização, que define como sendo seu movimento, a sua capacidade de enfrentar desafios e a sua capacidade de mudança. Já o trabalho de Aulicino (1998) consiste da aplicação dessa teoria à organização do trabalho dos grupos de operadores de refinarias de petróleo. O foco é a divisão do trabalho entre esses grupos e a sua estruturação interna.

A seguir é feita uma breve discussão da teoria de projeto organizacional sociotécnico moderno, calcada nas propostas dos autores citados, iniciando por conceitos relativos à teoria sociotécnica moderna. Em seguida são abordados especificamente conceitos e regras de projeto organizacional que sintetizam uma forma de projetar organização bastante utilizada no norte da Europa, notadamente na Holanda, 
conforme o trabalho de Sitter; Hertog e Dankbaar (1997). O enfoque dado por Salerno $(1999,2007)$, relativo a eventos e à comunicação, também é considerado na discussão.

São apresentados posteriormente fundamentos teóricos acerca da coordenação do trabalho dentro e entre unidades organizacionais. Embora essa questão da coordenação não apareça, pelo menos de modo direto, na teoria de projeto organizacional de referência, ela mostrou-se bastante importante ao longo da pesquisa, como será visto nos próximos capítulos.

Outras fontes bibliográficas são utilizadas para clarear conceitos embutidos na teoria de projeto organizacional. Algumas considerações adicionais à bibliografia pesquisada foram acrescentadas, visando maior compreensão da teoria e incluindo exemplos relativos aos processos contínuos de fabricação, colhidos na pesquisa de campo realizada ${ }^{2}$.

\subsubsection{Teoria Sociotécnica Moderna}

A teoria sociotécnica moderna desenvolveu-se a partir da década de 70, representando uma evolução da sociotécnica tradicional de cunho analíticoprescritivo para uma teoria de projetos. Principalmente no norte da Europa, essa abordagem teórica correspondeu à prática organizacional adotada em diversas empresas. Na Holanda, o envolvimento das universidades e órgãos governamentais com as empresas permitiu desenvolvimento, aplicação e validação da teoria sociotécnica moderna, com grande enfoque em projeto organizacional, registrada em trabalhos acadêmicos. $O$ estudo desses trabalhos possibilita apresentar a seguir a base conceitual da teoria sociotécnica moderna a partir de alguns de seus autores (SITTER et al., 1994,1997; EIJNATTEN e ZWAAN, 1998).

\footnotetext{
${ }^{2}$ Essas considerações são decorrentes de discussões teóricas do autor com o orientador e informações da literatura (SALERNO, 1999; 2007; AULICINO, 1998).
} 
Uma diferença importante entre a sociotécnica tradicional e a sociotécnica moderna diz respeito aos sistemas técnico e social. A abordagem tradicional identifica esses dois sistemas nas organizações e prescreve o tratamento separado de cada um deles, promovendo a junção posterior dos dois em busca da otimização da organização. Já a abordagem moderna rejeita essa separação da organização em sistemas, pois um dos princípios dessa abordagem é considerar o sistema de produção como um sistema funcional integral e os seguidores dessa corrente entendem que a sua divisão em dois sistemas separados contradiz a noção de sistema integral.

Para a teoria organizacional moderna, o sistema é único e constituído apenas por elementos humanos; quaisquer que sejam seus cargos, operadores, técnicos, analistas, engenheiros, gerentes, ou ainda, grupos e unidades organizacionais, que se relacionam para desempenhar determinadas funções. Máquinas, matériasprimas, informações etc, são meios usados para desempenhar as operações e transformações do sistema de produção. Isso não impede que se distingam subsistemas. Se um sistema é um conjunto de elementos que interagem para a realização de um rol de funções, pode-se dizer que os elementos que interagem para a realização de cada uma dessas funções (como planejamento, funções de fabricação e vendas) constituem subsistemas.

Se por um lado a sociotécnica moderna rejeita a separação da organização em dois sistemas, de outra forma enxerga no sistema único e integral diferentes aspectos, aos quais denominou aspectos sistêmicos. Dois deles são aspectos básicos, presentes em todo o sistema: o aspecto sistêmico produção (ou execução) e o aspecto sistêmico controle. Ao primeiro, corresponde a estrutura organizacional do trabalho de execução e ao segundo a estrutura organizacional do trabalho de controle. Outros exemplos de aspectos sistêmicos são qualidade, logística, manutenção, gestão das pessoas etc., podendo corresponder a subsistemas.

À primeira vista, a existência dessas duas estruturas organizacionais pode parecer uma incoerência ao princípio de sistema integral. Entretanto, como poderá ser percebido mais adiante, as duas estruturas são compostas dos elementos do sistema organizacional (lembrar: os elementos são humanos), preservando a integralidade do sistema. 
A estrutura de produção compreende o conjunto completo das rotas e seqüências pelas quais os processos operacionais podem se realizar, com suas inter-relações e compatibilidades. Essas inter-relações podem ser técnicas, informacionais e operacionais. Os elementos do sistema organizacional - as pessoas - são os catalisadores do sistema de produção.

As rotas e seqüências, e podem ser acrescentados procedimentos e parâmetros dos processos de produção, entretanto, não são automáticos. Estão sujeitos a regulação, normatização, ou seja, controle, por razões de eficiência e eficácia, o que constitui o sistema de controle, que corresponde a uma estrutura de governança separada do sistema de produção. Na sociotécnica moderna, os empregados constituem a base do sistema de controle. O conceito de estrutura de controle como um aspecto sistêmico está relacionado à composição e distribuição de todos os tipos de controles, incluindo autoridade e competência, com relação à logística, qualidade, desenvolvimento de produto e manutenção, dentre outros possíveis aspectos transversais ao sistema, ou seja, aspectos que transpassam todo o sistema de produção.

Em complemento às estruturas de produção e controle, pode ser útil definir-se uma estrutura de informação, que, entretanto, deve ser função das outras duas.

\subsubsection{Conceitos do Projeto Organizacional Sociotécnico Moderno}

a) Conceito de Projeto Integral - O projeto da estrutura organizacional deve basear-se nas interações entre os subsistemas funcionais, como vendas, projeto do produto, planejamento, funções de fabricação, embalagem etc., e aspectos transversais do sistema que caracterizam seus atributos gerais, como qualidade, logística, manutenção e pessoal. As ligações entre os elementos do sistema envolvido nos diversos cruzamentos de subsistemas e aspectos do sistema são dependentes do desenho da estrutura. 
b) Conceito de Controlabilidade - Nesse caso, controle refere-se à criação de condições estruturais para as oportunidades de formulação e implementação de metas. Não se trata de criar uma capacidade do sistema controlar metas específicas, prescritas previamente, mas de desenvolver a capacidade organizacional de formular, reformular e perseguir metas, considerando que não se conhecem as necessidades futuras que implicarão em novas metas ou as mudanças das condições em que se deve atingi-las. Incluem-se aí as necessidades de adaptações para atingir metas devido a problemas técnicos, comerciais, de desenvolvimento de produtos etc. Logo, o projeto organizacional deve desenvolver a capacidade de pilotar, de dirigir os processos do sistema de produção. Daí esse conceito corresponder ao termo dirigibilidade. A dirigibilidade pode ser representada pela relação entre as variações requeridas nos processos e a possibilidade de efetuá-las.

c) Conceito Duplo de Estrutura de Produção e Controle - O controle deve ser entendido como direção, no sentido da dirigibilidade, conforme explicitado acima. A arquitetura da estrutura do sistema de produção aumenta ou restringe as chances de uma direção eficaz com relação às interferências entre os processos no que diz respeito aos resultados de cada um deles. Portanto, o projeto organizacional deve analisar os parâmetros estruturais que determinam as probabilidades de interferências e a sensibilidade às interferências, isto é, capacidade de reduzir distúrbios. Do ponto de vista de metodologia de projeto, é útil que três aspectos sejam diferenciados:

- Estrutura de produção: agrupamento e inter-relacionamento das funções de execução;

- Estrutura de controle: alocação e inter-relacionamento das funções relativas à dirigibilidade;

- Estrutura de informação: no projeto sociotécnico, deriva das estruturas de produção e controle e está relacionada a questões técnicas como transferência de dados para tomada de decisão e ação sobre os processos, auxiliando a pilotagem dos processos.

d) Conceito de Parâmetros Estruturais - Os parâmetros referem-se às características primárias das estruturas de produção e controle. Os projetistas devem conhecer como esses parâmetros se relacionam às necessidades e 
deficiências organizacionais, analisando quais são relevantes para um dado projeto. Uma relação de parâmetros estruturais é discutida a seguir:

\section{Concentração Funcional}

Diz respeito a como as funções de execução são agrupadas ou ligadas com relação às ordens de produção ou às transformações entradas/saídas. Há duas possibilidades extremas: atribuição das ordens de produção a todos os subsistemas (como num arranjo funcional de metalúrgicas, quando a ordem vai para a tornearia, para a seção de fresa, de retífica, para a montagem etc.) ou atribuição de cada ordem a apenas um subsistema específico, como num arranjo celular, tratando-se no primeiro caso da concentração e no segundo da desconcentração do sistema em fluxos paralelos. A questão central aqui é a paralelização dos fluxos, que aumenta em muito a dirigibilidade do sistema. Por exemplo, se uma fábrica embala todos os seus produtos numa mesma linha, há muita vulnerabilidade a falhas de equipamento, de operação; o teste de uma nova embalagem ou do envase de um novo produto significa tornar o equipamento indisponível para a produção normal. Já se houvesse duas linhas de capacidade unitária menor, aumentaria a capacidade de fazer frente a eventos, aumentaria a dirigibilidade.

No caso dos processos contínuos, onde as unidades de produção são de grande porte e demandam altos investimentos, a paralelização pode ocorrer, por exemplo, aproveitando uma ampliação da fábrica através da construção de novas unidades (ou plantas). Nesse caso, pode haver a separação de tipos de matérias-primas, destinando-as a unidades diferentes, reduzindo a necessidade de ajustes nos processos ou a programação da produção de determinada especificação de produtos em apenas uma das unidades existentes. Evidentemente, é necessário análise de investimento, pois pode haver ganhos de escala na concentração funcional, mas esses estudos deveriam considerar não apenas a capacidade teórica dos equipamentos mas sim como os equipamentos poderão vir a ser ocupados em função das estratégias da empresa - quanto menos visível for o futuro em termos de produto, configurações de processo, objetivos de produção etc, mais importante é a paralelização. A definição acerca de concentração e desconcentração é, portanto, decisiva, pois limita a liberdade de definição dos demais parâmetros estruturais. 


\section{Diferenciação da execução}

Refere-se à divisão das funções de preparar, apoiar e produzir em subsistemas especializados. Por exemplo, como é a divisão de trabalho entre preparação, alimentação e operação de uma parte do processo - essas atividades são atribuídas a uma única unidade organizacional ou a diversas unidades (quando há um setor que cuida da preparação, outros do apoio e outro ainda da produção direta propriamente dita). Um exemplo simples de manufatura, pode ser o de usinagem CNC: a preparação da máquina pode ser feita pela manutenção, a programação CNC pelo setor de processos, a produção pela operação e o apoio pela manutenção, qualidade e engenharia de fábrica, criando uma estrutura bastante complexa. Em um processo contínuo, como no caso da refinaria de petróleo, existem as atividades de preparação - análise do petróleo, sua preparação, carga, ajuste da unidade de produção e operação propriamente dita. A análise, nesses casos estudados, é realizada pelo setor de laboratório, do domínio da Engenharia, a preparação e a carga pela gerência de Transferência e Estocagem, já o ajuste da unidade (de certa forma equivalente ao set up na manufatura), pelo próprio pessoal de operação de processo das unidades, revelando haver divisão de trabalho entre as subfunções de operação e apoio. Nesse caso, a divisão envolve mais de um segmento organizacional de funções diferentes (Engenharia e Operação).

\section{Especialização da execução}

Refere-se ao desmembramento de uma subfunção de execução em atividades de execução, alocadas em subsistemas separados. Por exemplo, atividades de preparação alocadas entre unidades organizacionais (ou subsistemas) diferentes, como quando a manutenção afia ferramentas, a engenharia carrega o software, a qualidade instala medidores etc. No caso de processos contínuos, um exemplo de especialização seria quando a área de Operação solicita à área de Manutenção abrir tampas de equipamentos, com tarefas como instalar andaimes, remover parafusos e juntas, soltar conexões, movimentar cargas com guinchos e guindastes se as peças forem de grandes dimensões, outro exemplo, instalação temporária de dispositivos (linhas, instrumentos de medição de temperatura de pressão e vazão etc.), quando essas atividades são realizadas por instrumentistas e encanadores para possibilitar a realização de drenagens e de limpezas de equipamentos pela operação. 


\section{Separação das funções de execução e controle}

Definir se o controle dos processos é feito pelos seus executantes ou por elementos diferentes ou ainda, subsistemas diferentes, homens com uso ou não de máquinas. Cabe destacar que o próprio trabalho operacional dos processos contínuos é, em grande parte, uma atividade de controle, na qual os operadores monitoram e ajustam as variáveis dos processos de transformação das diversas matérias-primas e produtos intermediários em produtos desejados, não apenas segundo parâmetros de processos determinados, mas conforme as condições do processo. Esse controle (pilotagem) é exercido tanto sobre as variáveis dos processos (temperaturas, pressões, vazões) como sobre as condições de funcionamento dos equipamentos.

\section{Especialização do controle}

Alocação do controle de aspectos funcionais a aspectos do sistema separados, como qualidade, manutenção, logística, pessoal etc. Um exemplo simples e clássico é atribuir o controle de qualidade a um setor externo à produção direta. No caso dos processos contínuos, onde a qualidade dos produtos é medida por ensaios químicos para determinar as suas propriedades, é comum haver um setor de laboratório especializado na realização desses ensaios - comumente, uma unidade organizacional à parte (controle de qualidade ou assemelhado), ainda que a literatura aponte casos de laboratório e de análises laboratoriais integrados à produção direta (SALERNO, 1999). Outro exemplo ocorre nas grandes siderúrgicas, nos casos em que o setor de Programação e Controle da Produção (PCP) exerce o controle de todo o material em linha de produção, que atravessa as diversas fábricas que compõem a usina siderúrgica.

\section{Diferenciação do controle}

Desmembramento dos domínios de controle em níveis separados - estratégico, tático e operacional - alocados a partes diferentes da estrutura organizacional. Envolve questões como a definição de metas para o sistema de produção e 
implantação de ações tendo em vista as metas definidas. Muitas vezes essas metas e ações envolvem exigências de origem externa ao sistema de produção, como alterações de mercado, nova legislação ambiental e novas tecnologias. Assim, a diferenciação do controle implica em alocar o tratamento de questões como essas, que escapam aos limites das atividades operacionais, em segmentos da organização diferentes daqueles mais voltados ao trabalho operacional, como a Engenharia ao invés da Operação e da Manutenção.

\section{Divisão das funções de controle}

Alocação das atividades de detecção e percepção, avaliação e definição de ações a indivíduos, elementos do sistema ou subsistemas diferentes. Pode-se relacionar este fundamento novamente ao exemplo das análises realizadas em laboratório de matérias-primas, produtos intermediários e produtos finais, que podem significar a detecção de desvios. A análise e definição de ações cabem aos segmentos de operação, podendo contar ainda com a participação da engenharia de processo.

\subsubsection{Eventos e Comunicação}

A observação do trabalho nos sistemas de produção evidencia que em situações que fogem à rotina das estruturas organizacionais baseadas apenas nos desenhos de processos e atividades nem sempre dão a melhor resposta. É preciso que o projeto organizacional considere as situações não rotineiras, é necessário que se trate da dinâmica da organização, ou seja, das variações que ocorrem em torno da estrutura organizacional concebida. Alguns exemplos que foram vistos na pesquisa realizada são a constituição de grupos temporários para solução de problemas e a coordenação pela Engenharia de parte do trabalho da Operação em situações que envolvem aspectos técnicos dominados pelos engenheiros. Uma questão que se apresenta nesse contexto é como acontece a coordenação entre os domínios que intervém nessas situações. Em razão do exposto, é útil introduzir na discussão o 
conceito de evento como nucleador dos arranjos organizacionais (PAVA, 1983; AULICINO, 1998; SALERNO, 1999).

Os eventos do sistema de produção incluem todos os acontecimentos de quebra da rotina operacional. Panes em equipamentos, descontroles de variáveis de processos com relação aos parâmetros especificados e desvios de qualidade são eventos da produção. Mas também variações na gestão do sistema de produção, como utilização de novos tipos de matéria-prima e introdução de novas especificações de produto fazem parte dessa definição de eventos. A importância dos eventos na organização do trabalho nos sistemas de produção pode ser evidenciada no trecho reproduzido abaixo:

Tomemos o exemplo de uma pane. Se a pane é percebida como um puro azar, que deve ser suprimido o mais rápido possível, seu caráter positivo e de evento é abafado. A pane é definida negativamente como a interrupção súbita de operações mecânicas. Permanece dentro de uma lógica antiga. Ao contrário, se a pane for definida positivamente como uma ocasião de aprendizagem dos processos pelos trabalhadores diretamente envolvidos e ocasião de troca com os especialistas da manutenção, ela se torna um evento. Ela se torna um momento privilegiado ao qual uma comunidade de indivíduos poderá dar um sentido positivo que poderá fazer evoluir:

- os conhecimentos técnicos;

- as trocas sociais entre as diferentes categorias profissionais;

- o desempenho dos processos.

Graças à reconstituição das causas da pane (ZARIFIAN e AUBÉ, 1992, p.63).

Pode-se dizer que o conceito de evento apresentado dá um significado comunicacional e de aprendizagem às variações do sistema de produção. A comunicação, no âmbito da abordagem proposta de organização do trabalho tem um significado mais amplo e mais profundo que o da emissão de mensagens, recepção e feedback, da comunicação social. Visando o desenvolvimento da organização, a comunicação efetiva entre diferentes segmentos organizacionais e entre profissionais de diferentes categorias deve ocorrer em três dimensões: cognitiva, normativa e expressiva. O tratamento adequado dos eventos da produção é uma questão central nesse conceito de comunicação (ZARIFIAN e AUBÉ, 1992; VELTZ e ZARIFIAN, 1993). 
Dimensão Cognitiva: é a colocação em comum dos conhecimentos dos diferentes tipos de profissionais que atuam no sistema de produção e os entendimentos realizados acerca da validade desses conhecimentos frente às situações que se apresentam. Não se trata de uma simples superposição de conhecimentos dominados por diferentes áreas ou profissionais, mas da obtenção de compreensão comum acerca das situações. Os eventos são as ocasiões que permitem o compartilhamento de conhecimentos e construção de referenciais comuns entre os diversos segmentos e categorias profissionais do sistema de produção.

Essa dimensão pode ser exemplificada com o caso levantado em entrevista com gerentes e engenheiros da Fertilizantes, em que se constatou a formação de um sal indesejado na composição química de um dos produtos intermediários do processo. Que competências mobilizar para identificar a causa ou causas do problema, que poderiam ser problemas com equipamentos, problemas na operação do processo ou uma combinação dos dois? E depois de identificadas as causas, como sanear o problema? Nesse caso, tanto a identificação como a solução envolveram Operação, Manutenção e Engenharia conjuntamente.

Dimensão Normativa: é a que permite a ligação entre os objetivos centrais da organização (estratégicos e táticos) aos objetivos locais (operacionais). Concretamente, o estabelecimento de "zonas de explicitação e de questionamento dos objetivos, situadas entre o nível estratégico propriamente dito e o nível operacional" (VELTZ e ZARIFIAN, 1993:21). Essa comunicação permite a cada um reelaborar os objetivos estratégicos em objetivos locais, permitindo o julgamento de significado dos eventos da produção.

Por exemplo, implantar mudanças nos procedimentos operacionais de fabricação, como os de operação de fornos e caldeiras, com a finalidade de atingir novas metas de preservação do ambiente.

Dimensão Expressiva: essa dimensão é relativa aos motivos pessoais envolvidos na atividade profissional e nas relações sociais dentro da empresa. É a oportunidade 
dos indivíduos conciliaram seus motivos pessoais e recompensas com os projetos e necessidades da empresa.

\subsubsection{Espaços de Comunicação e Negociação}

A partir do significado dado acima à comunicação e tendo em conta a realização do trabalho na produção em grupos, seguindo a tradição sociotécnica, Salerno (1999) propõe que o projeto organizacional contemple a criação de espaços para a ocorrência dessa comunicação.

É oportuno fazer-se um parêntese para destacar que grupos de operadores são o arranjo usual na operação dos processos contínuos. Além disso, esses grupos possuem certos graus de autonomia para tomar decisões sobre o próprio trabalho, em razão das atividades que realizam de controle do processo, que foge da tradicional alocação rígida de postos de trabalho das linhas de montagem, tornando a produção contínua o tipo de produção que teoricamente mais se adapta ao esquema de grupos semi-autônomos (MARX, 1997; AULICINO, 1998).

Nesse contexto, o processo comunicacional, coerentemente com as dimensões da comunicação apresentados, deve ser um processo de intercompreensão entre sujeitos. Supõe não apenas a disponibilidade das informações, mas que elas sejam socialmente validadas e compartilhadas para que passem a fazer parte dos quadros de referência dos profissionais e dos diferentes grupos que atuam no sistema de produção e que se constituam em meio de coordenação das tarefas e ações que devem realizar e tomar. Dentre os possíveis espaços a serem criados, constam reuniões de planejamento, de análise e discussão de eventos, reuniões de troca de turno, reuniões gerais etc. Salerno (1999) recomenda que essas reuniões sejam bem planejadas e programadas, a fim de que sejam produtivas e não se tornem um estorvo por não terem objetivos e objetividade. 


\subsubsection{Sistemas de Informação}

Os sistemas de informação, com o uso das tecnologias mais apropriadas, devem ser meios para a intercompreensão de indivíduos, para apoio à tomada de decisões frente a eventos, para facilitar a dirigibilidade dos sistemas de produção, através do acesso e da produção de informações.

\subsubsection{Regras de Projeto}

As regras para elaboração de projeto organizacional do trabalho são apresentadas tanto por Sitter, Dankbaar e Hertog (1997) como por Salerno $(1999,2007)$ e foram utilizadas por Aulicino (1998) no estudo da organização do trabalho de grupos de operadores em refinaria de petróleo. Resumidamente são elencadas a seguir:

a) Projeto da estrutura de execução - análise da viabilidade e oportunidade da paralelização: a introdução de fluxos paralelos de fabricação permite reduzir a incidência de variações sobre o sistema de produção, por exemplo, direcionando variações de demanda ou de matéria-prima a uma das rotas de fluxo, preservando os outros fluxos das variações decorrentes. A paralelização está relacionada ao parâmetro estrutural concentração funcional.

b) Projeto da estrutura de execução - segmentação: as variações dos processos se amplificam com o crescimento do número de interfaces entre as funções do sistema de produção. Então um dos balizadores da determinação dos segmentos deve ser a internalização a eles do maior número possível de interfaces, ou seja, de conjuntos de operações com várias interdependências. Visa-se diminuir o número de unidades organizacionais (grupos, seções, departamentos), reduzindo, por conseqüência, o número de interfaces. A 
segmentação está relacionada aos parâmetros estruturais diferenciação e especialização da execução.

c) Projeto da estrutura de controle - buscar reduzir a separação das etapas do ciclo de controle (percepção, avaliação, integração de aspectos e definição de ação). A necessidade de separação dos ciclos de controle fica reduzida projetando-se a estrutura de produção (paralelização e segmentação) antes da estrutura de controle. Os quatro parâmetros estruturais relativos ao controle estão relacionados com essa regra de projeto.

d) Projetar primeiro a estrutura de execução e no sentido top-down, ou seja, do nível macro, dos fluxos de produção, para o nível micro, dos grupos de trabalho.

e) O projeto da estrutura organizacional precede o projeto detalhado da tecnologia de processo, instrumentação e sistemas automáticos (tipo SDCD). A razão desta regra é que algumas definições do tipo o que e como automatizar, quem terá acesso ou poderá alterar configurações e parâmetros do SDCD, podem depender da organização adotada.

f) O projeto da estrutura de controle deve ser bottom-up. Ao contrário da estrutura de produção, alocar primeiro os ciclos de controle do nível micro e depois os ciclos dos níveis médio e global. O local das variações determina a alocação dos ciclos de controle correspondentes.

A tabela 2.1 mostra as regras de projeto organizacional, na forma de roteiro para projeto.

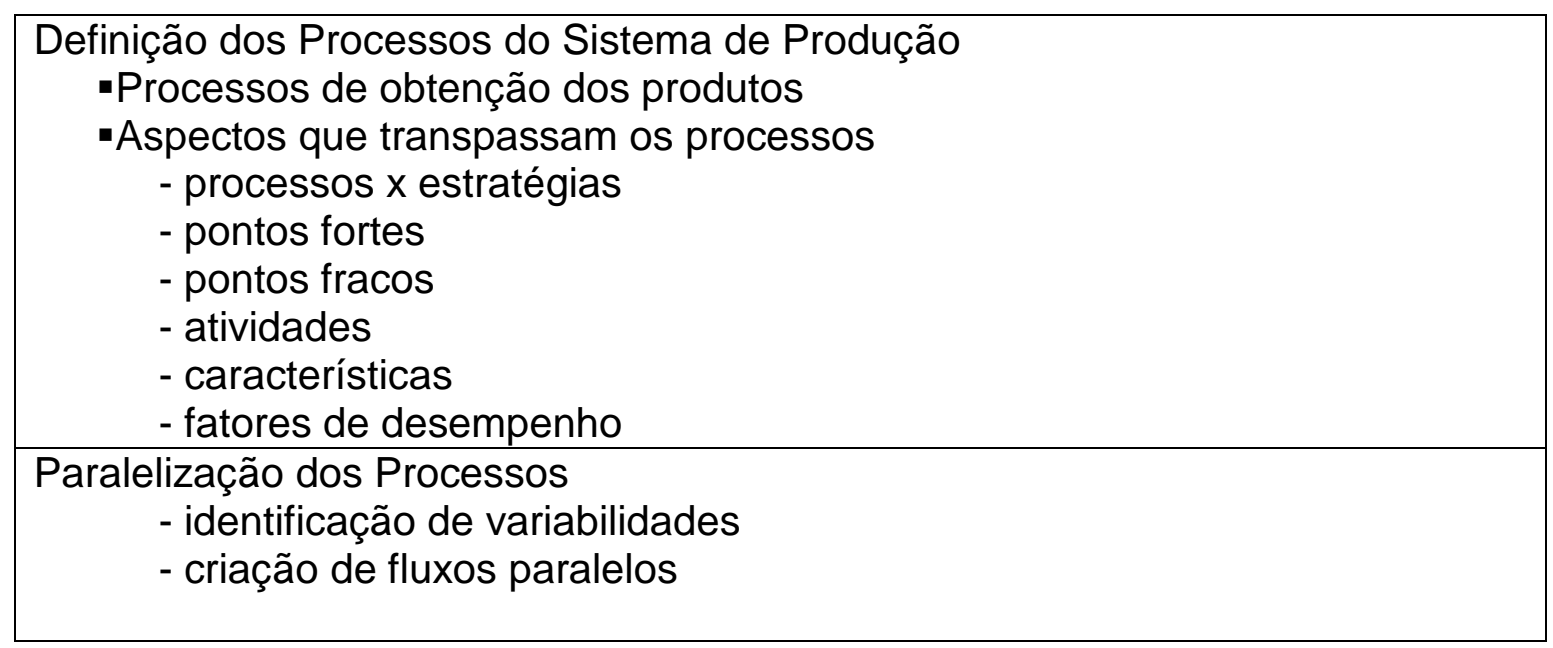


Segmentação dos Processos - projeto da estrutura de execução

- sentido top-down

- internalização de interfaces

- outros critérios de segmentação da sociotécnica: tempo, tecnologia e território

- pensar atividades que sejam divididas em preparação, apoio e execução

- pensar a conveniência ou necessidade de especialização

Projeto da estrutura de controle

- ciclos bottom-up

- separar ou não execução e controle

- especialização do controle

- diferenciação do controle

- divisão das funções de controle

Projeto Detalhado da Tecnologia de Processo

Sistema de Informações e Espaços Comunicação-Negociação

Tabela 2.1 (conclusão) - Roteiro para projeto organizacional do trabalho conforme a sociotecnologia moderna. Elaborado pelo autor a partir de Sitter et al. (1997); Salerno, (1999, 2007).

\subsection{COORDENAÇÃO}

Durante o desenvolvimento da pesquisa evidenciou-se a questão da coordenação da atuação da Operação, Engenharia e Manutenção no sistema de produção, porque ela emerge da análise dos dados levantados, desde a pesquisa inicial na RPBC. Ao examinar o referencial bibliográfico levantado, a questão da coordenação também chamou a atenção, porque a literatura de projeto sociotécnico trata do estabelecimento das fronteiras entre segmentos organizacionais, mas apenas tangencia a questão da coordenação nessas fronteiras quando trata da comunicação, principalmente ao referir-se aos espaços comunicacionais.

São necessárias, portanto, referências conceituais além daqueles dos pesquisadores sociotécnicos para abordar a questão da coordenação. Mintzberg (1993) é um dos autores que trata desse tema sob a ótica da estrutura organizacional. Segundo ele, a estrutura envolve dois elementos fundamentais: a 
divisão do trabalho em tarefas e a obtenção da coordenação entre essas tarefas. Embora não defina textualmente o que é coordenação, os exemplos dados por esse autor indicam que ele considera a coordenação como uma concatenação das tarefas em que foram divididas as atividades a serem executadas, onde se lidam com variáveis do tipo seqüência, tempo, fluxo etc.

Apesar das estruturas organizacionais apresentarem grande diversidade, Mintzberg considera que a combinação de um número limitado de configurações básicas representa a maioria das estruturas organizacionais tidas como eficazes. Assim do ponto de vista da coordenação, cinco mecanismos básicos de coordenação podem explicar os modos fundamentais pelos quais as organizações coordenam seu trabalho:

Ajuste mútuo: a coordenação do trabalho acontece simplesmente pelo processo de comunicação direta entre as pessoas que o executam. Acontece nas organizações mais simples onde poucas pessoas participam do trabalho o que permite o ajuste direto entre elas, mas também nas organizações mais complexas, como na agência espacial americana (Nasa), onde especialistas precisam conversar entre si para adaptar os resultados do seu trabalho, grande parte das vezes de desenvolvimento, a um caminho comum.

Supervisão direta: uma pessoa assume a responsabilidade pelo trabalho dos executantes, dando instruções e monitorando suas ações. Mintzberg (1993:4) relaciona este mecanismo a uma abordagem bastante clássica do trabalho - "um cérebro coordena diversas mãos".

Padronização dos processos de trabalho: quando o conteúdo do trabalho é especificado ou programado, ou seja, quando segue instruções padrões previamente definidas.

Padronização das saídas: quando os resultados do trabalho, por exemplo, as dimensões ou o desempenho do produto são especificados.

Padronização de conhecimentos e habilidades: quando há um tipo de treinamento especificado para desempenhar o trabalho. Pode ser formação escolar ou acadêmica para aquele trabalho.

$\mathrm{Na}$ realidade, as organizações utilizam ao mesmo tempo todos cinco modos, de maneira combinada e a necessidade de coordenação aumenta à medida que a 
empresa cresce e a organização do trabalho torna-se mais complicada. Mintzberg, ao longo do seu texto, correlaciona os cinco mecanismos de coordenação com a atuação de cada uma das cinco partes em que divide a estrutura organizacional:

Ápice estratégico: é a alta direção da organização - presidente, diretores e seus assessores.

Linha média: abrange todos os níveis de gerência e supervisão.

Núcleo operacional: inclui todos aqueles cujo trabalho está diretamente relacionado à produção de bens e serviços - os que vendem os produtos, os que cuidam do suprimento de matéria-prima, os que executam as transformações que geram os produtos, os que realizam as entregas e os que dão apoio direto, como o pessoal de manutenção.

Tecnoestrutura: os que servem à organização afetando o trabalho dos outros. São os analistas ligados com adaptações e mudanças para atender alterações do ambiente e aqueles relacionados ao controle, estabilização e padronização das atividades da organização. Inclui os que estudam e padronizam os processos de trabalho; os analistas planejadores e controladores, como os planejadores de longo prazo, engenheiros de controle de qualidade, programadores de produção e contadores, que padronizam as saídas; e os analistas de pessoal, que cuidam de recrutamento e treinamento, que padronizam as habilidades.

Suporte: é a parte da estrutura que providencia o apoio fora dos processos de trabalho das demais partes da estrutura, como pagamento de contas, seguros, serviços de segurança patrimonial, refeitórios, consultoria jurídica etc.

A tabela 2.2 apresenta uma correlação entre os mecanismos de coordenação e as partes da estrutura organizacional, conforme o modelo concebido por Mintzerg. Mostra também algumas atividades através das quais as pessoas que estão em cada parte da estrutura exercem a coordenação, principalmente sobre outras partes da estrutura. Não significa que haja exclusividade de qualquer parte da estrutura no uso do mecanismo relacionado a ela na tabela, nem que não utilize os demais mecanismos, mas que o mecanismo que está relacionado é aquele que mais representa o papel daquela parte da organização. 
É interessante destacar que os domínios organizacionais da Operação e da Manutenção correspondem ao núcleo operacional, enquanto a Engenharia corresponde à tecnoestrutura, nesse modelo de estrutura organizacional.

Para efeito desta tese, interessa utilizar como uma das referências teóricas a tipologia de mecanismos de coordenação elaborada por Mintzberg.

\begin{tabular}{|c|c|c|}
\hline $\begin{array}{l}\text { PARTE DA } \\
\text { ESTRUTURA }\end{array}$ & $\begin{array}{c}\text { PRINCIPAIS } \\
\text { MECANISMOS DE } \\
\text { COORDENAÇÃO } \\
\text { QUE EXERCE }\end{array}$ & $\begin{array}{l}\text { ATIVIDADES DE } \\
\text { COORDENAÇÃO }\end{array}$ \\
\hline Núcleo operacional & Ajuste mútuo & $\begin{array}{l}\text { Ajustes com os colegas de } \\
\text { trabalho. }\end{array}$ \\
\hline Ápice estratégico & Supervisão direta & $\begin{array}{l}\text { Alocação de recursos, emissão } \\
\text { de ordens, decisões maiores, } \\
\text { solução de conflitos, projeto da } \\
\text { organização, monitoração de } \\
\text { desempenho, motivação e } \\
\text { recompensa de empregados. }\end{array}$ \\
\hline Linha média & Supervisão direta & $\begin{array}{l}\text { Faz a conexão entre o ápice } \\
\text { estratégico e as demais partes } \\
\text { da organização, fazendo uma } \\
\text { espécie de fluxo de dois sentidos } \\
\text { entre eles. Gerencia fronteiras } \\
\text { com outras unidades organiza- } \\
\text { cionais e pessoas fora de sua } \\
\text { unidade. }\end{array}$ \\
\hline Tecnoestrutura & Padronização & $\begin{array}{l}\text { Padronização dos processos e } \\
\text { fluxos de trabalho, planejamento, } \\
\text { programação e controle da } \\
\text { produção, sistemas de } \\
\text { qualidade, definição de requisitos } \\
\text { de formação e de treinamento de } \\
\text { pessoal; planejamento estratégi- } \\
\text { co, monitoramento de resultados. }\end{array}$ \\
\hline Suporte & $\begin{array}{l}\text { Conforme } \\
\text { caso }\end{array}$ & Conforme cada caso \\
\hline
\end{tabular}

Tabela 2.2 - Mecanismos de coordenação e partes da estrutura organizacional. Elaborado pelo autor a partir de Mintzberg (1993). 


\section{METODOLOGIA DA PESQUISA}

O trabalho foi feito através de pesquisa bibliográfica, para a sustentação teórica ao tratamento do tema, e por meio de pesquisa de campo para levantar dados acerca das situações de interface das funções que atuam no sistema de produção, arranjos organizacionais e práticas de trabalho adotadas. A pesquisa bibliográfica e a pesquisa de campo forneceram os elementos que permitiram desenvolver e validar a proposta para projeto organizacional do trabalho em processos contínuos.

De início, a pesquisa bibliográfica visou identificar a teoria existente de organização do trabalho aplicável ao tema em estudo. Dentro das possibilidades, foram selecionadas principalmente referências da sociotécnica moderna. Essa abordagem se aplica bem aos objetivos deste trabalho, pois a sociotécnica moderna, e particularmente o trabalho desenvolvido na Holanda, ao contrário da escola sociotécnica tradicional, cuja preocupação principal era a qualidade de vida no trabalho, dá ênfase ao projeto organizacional visando não apenas a qualidade de vida no trabalho, mas objetivos de desempenho do sistema de produção, como aumento da flexibilidade, redução da burocracia e aumento da qualidade de produto (EIJNATTEN e ZWAAN, 1998; SITTER et al., 1994; 1997).

A abordagem sociotécnica moderna já foi utilizada pelo autor anteriormente, na dissertação de mestrado. Essa escolha teve em vista que os operadores dos sistemas de produção contínuos são organizados em equipes para realizar seu trabalho e na sociotécnica a referência para organização dos trabalhadores da produção são os grupos semi-autônomos (AULICINO, 1998; FERREIRA e IGUTI, 1996, MARX, 1997). E a dissertação de mestrado e esta tese estão relacionadas, pois se naquela ocasião foi estudada a organização do trabalho dos grupos de operadores de uma refinaria de petróleo, ou seja, olhando para dentro do domínio organizacional da Operação, o presente trabalho volta o olhar para as interfaces da Operação com outras funções. Adicionalmente, foi levado em conta que a sociotécnica visa abordar os aspectos social e técnico, envolvidos no problema objeto da pesquisa: se o projeto das interfaces é um problema organizacional, essas interfaces existem por causa de características técnicas dos sistemas de produção. 
O início da pesquisa de campo foi por meio da observação participante na Refinaria Presidente Bernardes de Cubatão, da Petrobras, tendo em vista a situação do pesquisador de profissional da Petrobras, atuando nessa refinaria de petróleo há cerca de vinte anos, o que lhe permite uma visão privilegiada do tema sob diversos pontos de vista, nas diversas funções que tem exercido: como engenheiro da Manutenção, como coordenador de turno na Operação, como coordenador de planejamento de obras de Engenharia e como engenheiro e gerente da área de planejamento, organização e gestão. O fato de fazer parte da organização estudada permite facilidade de acesso aos dados e a vantagem de já possuir conhecimento desse sistema de produção. Acrescente-se que o estudo da Refinaria de Cubatão é um caso relevante para o tema escolhido, pois se trata de uma refinaria que possui parque de refino complexo, com grau razoável e crescente de automação do seu sistema operacional e que, estando em operação há mais de cinqüenta anos, acumula grande experiência nesse tipo de processo de produção.

A observação focou problemas das interfaces no sistema de produção. Privilegiou-se o acompanhamento e análise de eventos envolvendo, potencial ou efetivamente, participação da Operação, da Manutenção e da Engenharia. Com isto, foram estudados os problemas de divisão do trabalho, as formas de coordenação levadas a cabo e seus limites, os atritos e as lacunas de competência, o limite da atuação de cada uma das funções.

Os dados inicialmente levantados da bibliografia pesquisada e aqueles obtidos por observação participante, no caso da Refinaria Presidente Bernardes - RPBC, formam o embasamento para a formulação inicial do problema e das hipóteses de pesquisa, bem como para o seu planejamento. É fundamental confrontar a teoria que está sendo desenvolvida ou hipóteses formuladas com a literatura existente. Isso envolve questionar o que é similar e o que é contraditório e por quê. Primeiro para suportar as similaridades e segundo, para dar confiança nas descobertas. $O$ resultado é validade mais forte dos resultados e maior poder de generalização em razão do maior nível conceitual (EISENHARDT, 1989).

Com a pesquisa bibliográfica inicial e dados da observação participante, a opção feita foi prosseguir a pesquisa utilizando a metodologia de estudos de casos. A escolha do método foi feita porque o estudo de caso é um método adequado para tratar "questões do tipo como e por que, que apresentam natureza mais exploratória, 
lidando com relações que se configuram no tempo e no contexto em estudo" (LAZZARINI, 1995). Trata-se do desenvolvimento de uma teoria de projeto, que poderá ser generalizada para outros casos, e não de estudar ocorrências em populações (YIN, 1994). Os estudos de caso, sem as restrições dos limites rígidos dos questionários e modelos, podem levar a percepções novas e criativas, desenvolvimento de novas teorias e têm grande validade entre os praticantes - os destinatários da pesquisa (VOSS et al., 2005). Esses atributos vão ao encontro das necessidades desta pesquisa, que visa propor desenvolvimentos à teoria de projeto organizacional existente, contemplando o projeto de organização das interfaces entre as funções que interferem diretamente na operação dos sistemas de produção. O foco é a produção por processos contínuos.

Com relação ao número de casos a serem estudados, cabem algumas considerações. A primeira é que quanto menor o número de casos, maior a oportunidade para um estudo aprofundado. Porém, uma limitação para o estudo de caso único é a generalização das conclusões, modelos ou teoria desenvolvidos. Outros problemas potenciais são o subjulgamento de um evento ou o exagero de dados de fácil aquisição. Embora esses riscos existam em todos os estudos de casos, podem ser mitigados quando comparados a outros casos.

Por outro lado, casos múltiplos podem reduzir a profundidade do estudo se os recursos forem uma restrição. Há que se considerar, ainda, que em algum momento o estudo de novos casos pouco acrescenta aos dados obtidos, principalmente quando tiverem sido abordados casos mais complexos que podem embutir diversos subcasos (VOSS et al., 2005; EISENHARDT, 1989).

A escolha dos casos a serem estudados ficou restrita aos sistemas de produção contínuos. A opção pelos sistemas de produção contínuos justifica-se metodologicamente em razão da limitação de recursos para se estudar uma grande quantidade de casos. Nessa situação, faz sentido escolher casos de solução extrema (PETTIGREW, 1988 apud EISENHARDT, 1989) e nos sistemas contínuos de produção as interfaces entre os diferentes domínios que atuam na operação do sistema de produção são mais comuns e também mais relevantes do que em outras formas de produção (KHURANA, 1999).

Como a ocorrência desse tipo de interfaces decorre da complexidade tecnológica e logística do sistema de produção e não de uma forma particular de organização, não 
se exige que as empresas estudadas se organizem segundo a escola sociotécnica, mas que os casos retratem as situações de interface entre Operação, Manutenção e Engenharia. A sociotecnologia moderna é a base conceitual a partir da qual será feita a análise dos casos.

A partir dessas considerações, foram escolhidos os casos da RPBC, pelas razões já expostas, e de outra empresa, que será chamada de Fertilizantes, cujos processos de fabricação são típicos da indústria petroquímica.

\begin{tabular}{|c|c|}
\hline VARIÁVEL DE PESQUISA & CONTEÚDO \\
\hline $\begin{array}{l}\text { 1.Identificação e relevância } \\
\text { das interfaces Engenharia / } \\
\text { Produção / Manutenção }\end{array}$ & $\begin{array}{l}\text { Variabilidades do sistema, eventos e interfaces; soluções de } \\
\text { problemas e melhorias; projetos; controle do sistema de produção; } \\
\text { curto X longo prazo; rotina X eventos significativos. }\end{array}$ \\
\hline 2.Natureza das interfaces & $\begin{array}{l}\text { Situações não rotineiras: como são tratadas? Quem assume a } \\
\text { liderança? Que formas de organização são adotadas? O que não } \\
\text { funciona bem? O que funciona bem? Situaç̃̃es rotineiras: há } \\
\text { estruturas para essas ocasiões? Quem lidera e decide? Por quê? } \\
\text { Quais os espaços e fóruns criados? Com relação ao ciclo dos } \\
\text { processos (ciclo longo X ciclo curto): há diferenças no tratamento? }\end{array}$ \\
\hline $\begin{array}{l}\text { 3.Paralelização e } \\
\text { segmentação das atividades } \\
\text { entre Operação, Manutenção e } \\
\text { Engenharia }\end{array}$ & $\begin{array}{l}\text { Quem controla ou executa o que? Incorporação versus separação } \\
\text { de engenheiros e especialistas da manutenção aos órgãos de } \\
\text { produção: qual a estrutura adotada? Por quê? }\end{array}$ \\
\hline 4.Diferenciação da execução & $\begin{array}{l}\text { Separação de atividades entre o pessoal da Operação, como } \\
\text { preparação e execução: essa separação se estende aos outros } \\
\text { domínios? Algumas dessas atividades são realizadas pelos outros } \\
\text { domínios? Idem para a Manutenção e para a Engenharia. }\end{array}$ \\
\hline 5.Especialização da execucãa & $\begin{array}{l}\text { Limites de conhecimento do processo de produção que são } \\
\text { supridos pela Engenharia e pela Manutenção; atividades da } \\
\text { produção que, por necessidade de conhecimento, são alocadas a } \\
\text { outros subsistemas, com a participação da Engenharia e da } \\
\text { Manutenção. }\end{array}$ \\
\hline
\end{tabular}

Tabela 3.1 (continua) 


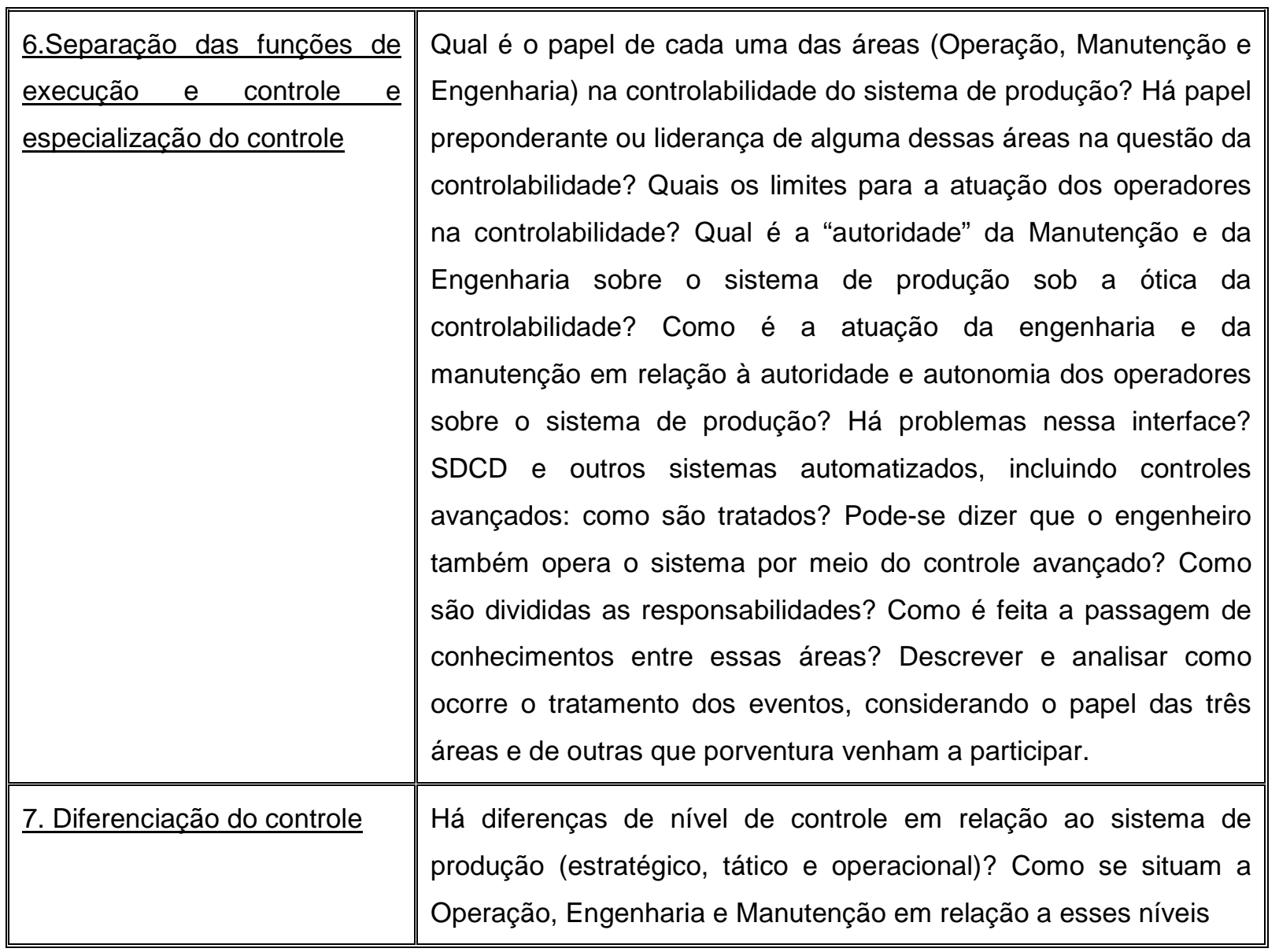

Tabela 3.1 (conclusão) - Variáveis de pesquisa. Elaborado pelo autor.

Em relação ao trabalho de campo, dois métodos de levantamento de dados foram utilizados. Um método é o de entrevistas com gerentes, engenheiros, técnicos e operadores. As entrevistas seguiram um roteiro elaborado a partir das variáveis de pesquisa, mostradas na tabela 3.1, escolhidas com base nos parâmetros de projeto organizacional obtidos da literatura e nas observações realizadas inicialmente na RPBC.

Foram realizadas entrevistas abertas, de modo a aumentar a interação entre pesquisador e entrevistado, daí a utilização de um roteiro de entrevistas (Anexo I) e não um questionário. Desse modo, procura-se dar chance a que o entrevistado possa introduzir aspectos do problema não relacionados anteriormente pelo pesquisador.

A técnica de entrevistas abertas atende principalmente finalidades exploratórias, sendo bastante utilizada para o detalhamento de questões e formulação mais precisas dos conceitos relacionados. Ela permite ao pesquisador obter o maior 
número possível de informações sobre determinado tema, segundo a visão do entrevistado, e também para obter um maior detalhamento do assunto em questão. É utilizada geralmente na descrição de casos individuais, na compreensão de especificidades culturais para determinados grupos e para comparabilidade de diversos casos (MINAYO, 1993 apud BONI e QUARESMA, 2005).

Em relação à estruturação das entrevistas, o entrevistador introduz o tema e o entrevistado tem liberdade para discorrer sobre o tema sugerido. As questões são desenvolvidas dentro de uma conversação informal. A interferência do entrevistador deve ser a mínima possível, este deve assumir uma postura de ouvinte e apenas em caso de extrema necessidade, ou para evitar o término precoce da entrevista, pode interromper a fala do informante.

O segundo método de levantamento de dados utilizado é o exame de documentos que forem colocados à disposição pelas organizações estudadas. O pesquisador teve acesso a organogramas, fluxogramas dos processos, manuais de gestão, normas e procedimentos de coordenação, relatórios de tratamento de ocorrências na produção nas duas empresas pesquisadas.

Algumas precauções devem ser tomadas para minimizar a influência de tendências pré-concebidas nos resultados da pesquisa, em razão de serem estudos de caso e da condição do pesquisador estar inserido em uma das organizações a serem pesquisadas.

A primeira precaução é o pesquisador tomar consciência da existência inevitável de vieses em todas as pesquisas e soluções elaboradas (THIOLENT, 1997). Como conseqüência dessa consciência, as entrevistas realizadas devem seguir o roteiro, baseado nas questões identificadas no referencial teórico e na observação participante, que serve de base para a interação entre pesquisador e entrevistados.

Há que se tomar o cuidado de não se elaborar um roteiro que delimite as observações dos entrevistados nem lhes direcione as respostas. Procuram-se evitar, dessa forma, distorções provenientes do reforço dos pontos de vista do pesquisador durante as entrevistas.

Outra precaução é realizar entrevistas com representantes de diferentes funções, no caso, gerentes, operadores, engenheiros e técnicos, e com mais de um entrevistado em cada função para cada empresa pesquisada. Procura-se, desse modo, obter os 
dados de posições diferentes de observação do sistema, minimizando as distorções decorrentes da visão de cada função em relação ao sistema produtivo. Da mesma forma, a exigência de mais de um entrevistado de cada função profissional procura reduzir as distorções das visões pessoais.

Se essa multiplicidade de entrevistados é utilizada para minimizar a incidência do viés nos dados colhidos, por outro lado serve para enriquecer a pesquisa ao agregar aspectos relevantes para análise desses mesmos dados.

Houve ainda a preocupação de verificar se as pessoas entrevistadas eram experientes nos sistemas de produção estudados, de modo a garantir a significância dos dados obtidos. Na RPBC, todos entrevistados possuíam mais de quinze anos de experiência. Já na Fertilizantes, a experiência mínima foi de cinco anos, exceto um operador que está há dois anos nesse cargo, destacando-se que a experiência dos gerentes de Operação e de Manutenção supera os vinte e cinco anos.

As tabelas 3.2 e 3.3 mostram os entrevistados em cada um dos casos estudados.

\begin{tabular}{||l||l||l||l|l||}
\hline & Gerente & Operador & Engenheiro & Técnico \\
\hline \hline Operação & 1 & 2 & & 1 \\
\hline \hline Engenharia & & & 3 & \\
\hline \hline Manutenção & 1 & & & 3 \\
\hline
\end{tabular}

Tabela 3.2 - Quantidade de entrevistados na RPBC por função profissional e área organizacional. Elaborado pelo autor.

\begin{tabular}{|l||l||l|l|l||}
\hline \hline & Gerente & Operador & Engenheiro & Técnico \\
\hline \hline Operação & 1 & 3 & & 1 \\
\hline \hline Engenharia & 1 & & 1 & \\
\hline \hline Manutenção & 1 & & 1 & \\
\hline
\end{tabular}

Tabela 3.3 - Quantidade de entrevistados na Fertilizantes por função profissional e área organizacional. Elaborado pelo autor. 
Quanto à análise dos dados, um processamento pobre das informações levaria ao perigo de se chegar a conclusões prematuras e falsas. A solução é analisar os dados de vários modos. Uma forma de se fazer isso é criar categorias ou dimensões e procurar similaridades dentro dos grupos e diferenças entre grupos. $O$ mesmo pode ser feito comparando-se casos dois a dois (EISENHARDT, 1989). Essa técnica foi aplicada na análise dos dados da pesquisa (Capítulo 5): os dados dos dois casos estudados foram separados em grupos de dados convergentes e grupos de dados divergentes para cada parâmetro de pesquisa.

A forma adotada para processar os dados obtidos dos entrevistados foi 0 agrupamento dos dados de todos os entrevistados de cada caso, segundo os itens do roteiro de entrevistas, procurando-se identificar, registrar e entender as convergências e divergências existentes nos dados fornecidos pelos entrevistados. Procurou-se assim, obter uma consolidação dos dados para cada caso estudado. Em seguida foi feita a comparação entre os casos.

Com o intuito de facilitar a análise dos dados consolidados, estes foram dispostos em tabelas para melhor visualização das congruências e das discrepâncias verificadas na comparação dos dados dos casos estudados para cada um dos parâmetros de pesquisa. Essa forma também facilita uma comparação entre dados obtidos e teoria existente, na busca de novas formulações teóricas, já que os parâmetros de pesquisa foram formulados levando em conta o referencial teórico existente.

Uma vez organizados os dados, é importante rever-se o levantamento bibliográfico realizado, para verificar se é necessário expandir-se a pesquisa da literatura para analisar os dados obtidos da pesquisa de campo. Por essa razão, diversas referências bibliográficas são utilizadas para a elaboração de proposições de métodos e conceitos para projeto organizacional, além daquelas que tratam diretamente do projeto sociotécnico moderno (Capítulo 6).

A idéia é comparar constantemente teoria e dados, de modo iterativo, em direção a uma teoria que se ajuste aos dados. Esse ajuste é importante porque pode resultar em novos insights dos dados e, ao mesmo tempo, permite obter uma teoria validada empiricamente (EISENHARDT, 1989). 


\section{PESQUISA DE CAMPO}

Foram estudados os casos de duas fábricas com sistemas de produção por processos contínuos: uma refinaria de petróleo e uma fábrica de produtos para a indústria de fertilizantes

No primeiro caso, o da Refinaria de Cubatão - RPBC, o pesquisador possui profundo conhecimento do seu sistema de produção e acesso à documentação pertinente (manuais de gestão, fluxogramas de processo, normas e procedimentos de trabalho, relatórios de ocorrências na produção etc.) por trabalhar nessa refinaria. Participa de decisões relativas à organização e coordenação dos trabalhos, envolvendo as três áreas enfocadas pela pesquisa, na função de gerente de planejamento e controle. Além disso, sua experiência profissional nessa organização inclui funções de Coordenador de Turno da Produção, organizacionalmente ligada à área de Operação, de engenheiro planejador e coordenador de paradas para manutenção e inspeção das unidades de produção, dentro da organização da área de Manutenção.

No outro caso, da empresa denominada de Fertilizantes, as informações foram colhidas das suas páginas na internet e de organogramas, normas e procedimentos a que teve acesso no decorrer das entrevistas realizadas.

Em todos os casos, entretanto, os principais dados foram obtidos das entrevistas realizadas com pessoas que atuam na Engenharia, Operação e Manutenção, em diferentes atividades. Mesmo no caso da Refinaria, embora o conhecimento do autor facilitasse o planejamento da pesquisa e a busca de informações, os dados que serão apresentados são provenientes das entrevistas realizadas e dos documentos consultados. Procurou-se evitar dessa forma a influência de possíveis vieses do pesquisador nos resultados do trabalho.

A comparação dos dados entre os dois casos e, em cada um deles, consolidação dos depoimentos de entrevistados de diversas áreas e funções possibilitou a validação dos dados colhidos. 


\subsection{O CASO DA REFINARIA DE PETRÓLEO - RPBC}

A RPBC - Refinaria Presidente Bernardes de Cubatão, pertencente à Petrobras, é uma das refinarias de petróleo mais complexo do Brasil, possui das maiores diversidades de unidades de processamento para refino de petróleo, gerando também uma grande diversidade de fluxos de produtos intermediários que vão compor uma grande gama de produtos finais. Possui atualmente cerca de 1.150 empregados. Também trabalham nas instalações, empregados dos prestadores de serviços.

É uma das primeiras refinarias do país, tendo passado por diversas reformas para substituição de equipamentos, ampliação e modernização. Na década de 90 , foram instalados sistemas digitais de controle distribuído - SDCD - em todas as unidades de processos e sistemas de controle avançado, que passaram a controlar as principais variáveis dos processos de fabricação por meio de algoritmos interligados ao SDCD. Novas malhas de controle avançado continuam a ser instaladas, ao mesmo tempo em que as existentes são aperfeiçoadas. Essas duas modernizações, SDCD e controles avançados, introduziram mudanças significativas no modo de trabalho de operação.

A estrutura organizacional da RPBC segue padrão da Petrobras para todas as suas refinarias, constituído por uma gerência geral, gerências funcionais, gerências setoriais ou coordenações e supervisões. As gerências setoriais e supervisões existem onde há uma quantidade significativa de pessoas que realizam atividades de execução, como operadores e profissionais de manutenção. Os coordenadores trabalham com equipes menores e atuam em atividades que demandam coordenação lateral. A seguir serão destacadas as áreas que têm atuação direta na atividade de produção. 


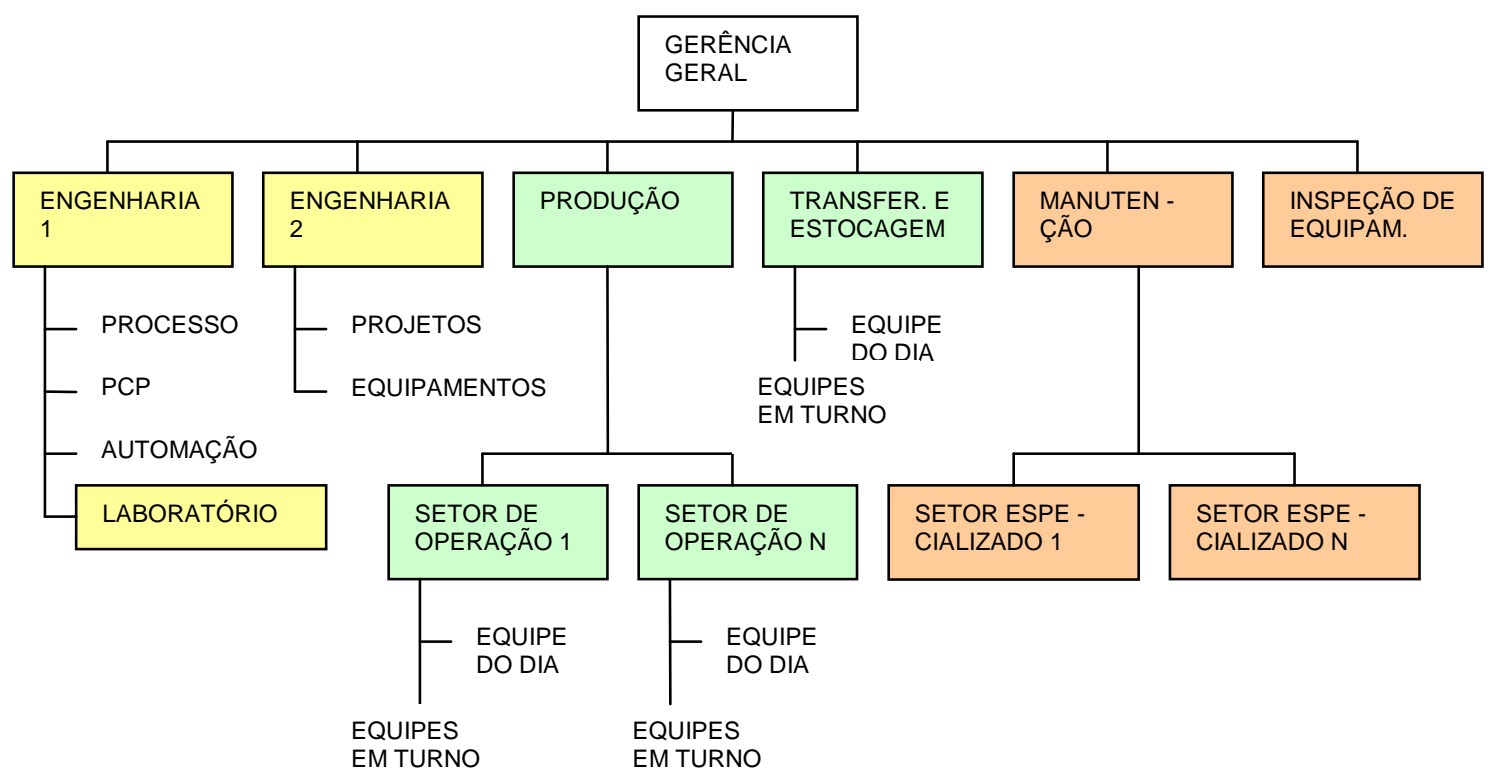

Fig. 4.1 - Organização estrutural do sistema de produção da RPBC. Elaborado pelo autor.

A área de Produção é encarregada da operação das unidades de processo, que realizam a transformação do petróleo em produtos intermediários ou finais. É dividida em gerências setoriais (setores de operação 1 a $N$ na fig. 4.1), cada uma delas correspondendo a grupos de unidades de processo, conforme critérios de tecnologia, território e fluxo de produção. Cada unidade de processo é um conjunto de equipamentos que realiza transformações desejadas na sua matéria-prima, empregando certo tipo de tecnologia de transformação e gerando produtos intermediários (que vão ser enviados para novas transformações em outras unidades de processo ou para tanques de armazenagem a fim de comporem produtos finais por mistura com outros produtos intermediários) e produtos finais, que são armazenados para expedição aos clientes (ver figura 4.2 - Fluxograma de produção). 


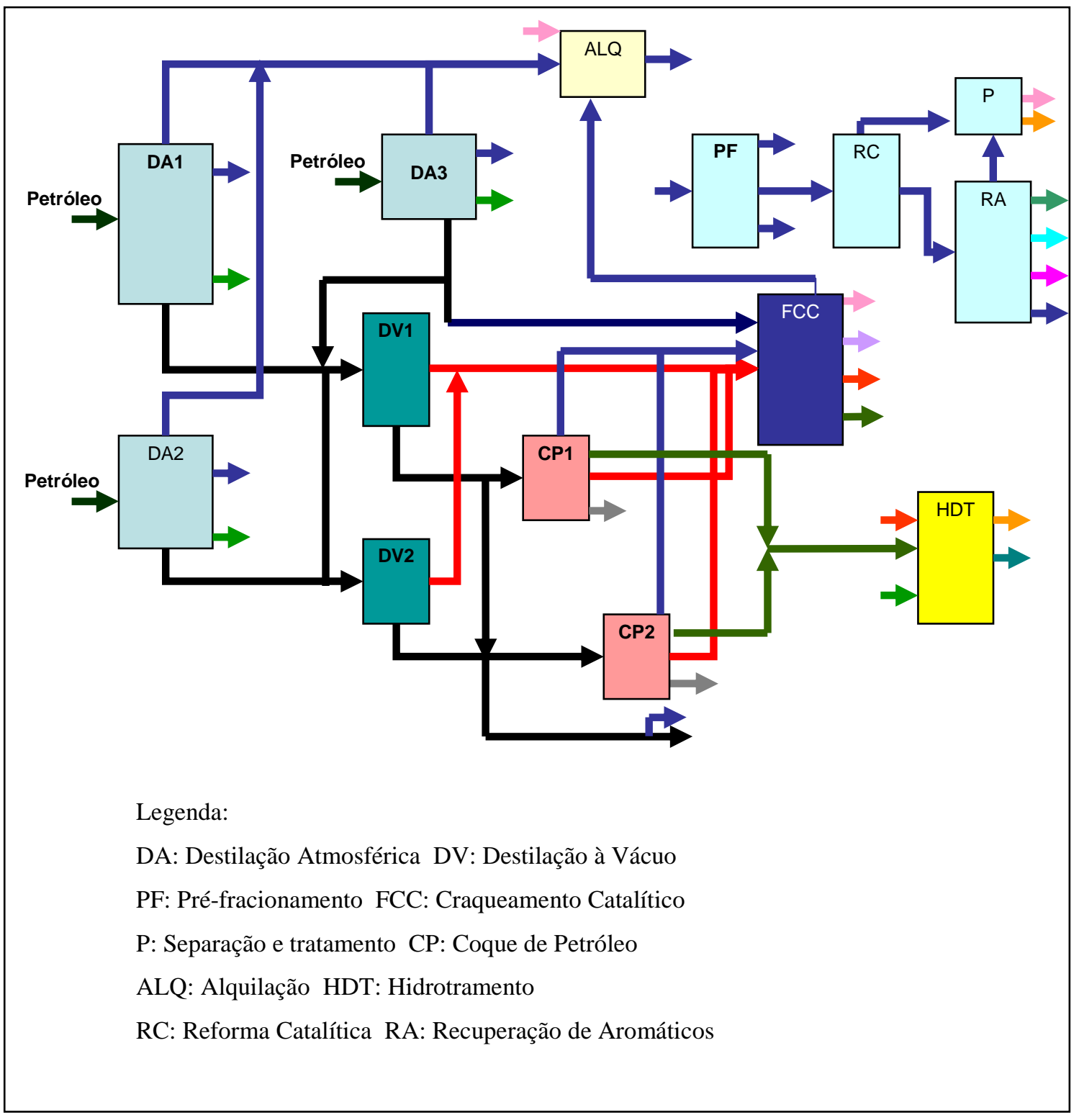

Figura 4.2 - Fluxograma Simplificado de Produção da RPBC. Fonte: RPBC (adaptado pelo autor).

Algumas das unidades de processo têm o objetivo de realizar tratamentos de remoção de contaminantes dos produtos produzidos, por exemplo, remoção de enxofre do óleo diesel. Há ainda unidades onde são tratados os resíduos do processo antes de serem descartados, com fim de reduzir o impacto no meioambiente e atender requisitos legais e compromissos com os órgãos ambientais regulamentadores e fiscalizadores (Cetesb, Ministério Público etc.), por exemplo, as unidades de tratamento de águas a serem enviadas para efluente e as de recuperação de enxofre de gases residuais. 
A operação das unidades de processo é realizada por equipes de operadores em turnos de revezamento. A divisão das equipes, dentro de cada gerência setorial, segue os critérios tradicionais da sociotécnica (CHERNS, 1979; SALERNO, 1991) tecnologia (fluxos e encadeamento das operações), tempo (turnos) e território (localização física dos processos e do aparato de controle). Em cada horário de turno há um supervisor por gerência setorial e um coordenador de turno, que responde pela coordenação geral do sistema de produção naquele horário.

Existem grupos constituídos por técnicos de operação e operadores que trabalham em horário administrativo dando suporte técnico e administrativo a cada gerente setorial e executando atividades de cunho operacional. Estas incluem 0 acompanhamento da montagem de projetos de engenharia e de trabalhos não rotineiros de manutenção. É através destes grupos que se realizam a maior parte das interfaces com a Engenharia e a Manutenção.

Atualmente, uma gerência denominada Transferência e Estocagem opera o sistema de tubulações e tanques através do qual o petróleo é recebido, armazenado, preparado e enviado às unidades para refino. Recebe e estoca correntes intermediárias dos processos e correntes para produtos finais, compondo os produtos finais com as correntes recebidas. É responsável pela expedição dos produtos através dos sistemas de dutos. À semelhança da Gerência de Produção, os operadores formam equipes com um supervisor por turno e há uma equipe de suporte ao gerente no horário administrativo.

As áreas de Produção e Transferência e Estocagem constituem a função Operação. Por configurarem uma parte da estrutura organizacional também são chamadas nesta pesquisa de domínio organizacional da Operação.

A função Engenharia conta com duas gerências. Uma gerência é equivalente à engenharia de processos (ver fig. 4.1: Engenharia 1), realizando trabalho de acompanhamento e otimização dos processos de fabricação. Estuda os parâmetros dos processos físico-químicos de transformação e os avalia tendo em vista a qualidade dos produtos, a economia energética, a minimização de perdas, o melhor rendimento da matéria-prima etc. Com esse foco, especifica valores para os parâmetros de controle dos processos de fabricação, dá assessoria técnica às gerências de Operação, elabora projetos conceituais para melhorias dos processos de fabricação, realiza projetos de automação, avalia e estuda a qualidade dos 
produtos. As atividades de análises de laboratório, tanto para testes dos processos e produtos como para controle de qualidade, e o planejamento e controle da programação da produção estão ligadas a essa gerência. Sua estrutura é formada por uma equipe de engenheiros de processo ligada ao gerente, uma equipe de programação de produção, uma equipe de engenharia de automação de processos, cada uma com um coordenador, e uma gerência setorial que responde pelas análises de laboratório.

A outra gerência da função engenharia (ver fig. 4.1: Engenharia 2) é responsável pelo projeto básico e de detalhamento e pela implementação de projetos de melhorias dos processos, ou seja, modificações técnicas nas unidades de produção para eliminar problemas de confiabilidade, aumentar a eficiência dos equipamentos e sistemas, modernização etc. Usualmente, esses projetos decorrem de solicitações das demais áreas. Além da implementação dos projetos, esse segmento organizacional presta suporte técnico de engenharia de equipamentos, estudando falhas dos equipamentos do sistema de produção e apontando as soluções técnicas pertinentes. Para cada uma dessas atividades, há uma equipe composta por engenheiros e técnicos, cada uma delas com um coordenador.

A Manutenção responde pela conservação e reparo dos equipamentos de toda a refinaria. Sua estrutura é composta pela gerência, gerências setoriais, divididas por especialidades, que aparecem na fig. 4.1 com o nome de setores especializados, e supervisores ligados aos gerentes setoriais. Parte significativa dos serviços dessa gerência é terceirizada, permanecendo a coordenação pela estrutura própria.

Para realizar o planejamento, programação e coordenação dos trabalhos de manutenção foram criadas equipes, chamadas na empresa de equipes de continuidade operacional. Essas equipes seguem a divisão das gerências setoriais da Produção e são compostas por supervisores de cada especialidade de manutenção e operadores. Têm a função de planejar, programar, coordenar e supervisionar, no caso de mão-de-obra própria, ou fiscalizar, no caso de serviços de terceiros, as intervenções de manutenção de forma a evitar ou minimizar as perdas de produção por falhas de equipamentos. Cada gerência setorial possui ainda equipes técnicas e de execução responsáveis pelos serviços de oficina, elaboração de contratos, monitoramento das condições de confiabilidade dos equipamentos, gestão de sobressalentes, trabalhos técnicos etc. 
Devido à importância do monitoramento da integridade física dos equipamentos, há uma gerência específica para tratar desse assunto, que avalia o desgaste e a deterioração dos equipamentos, recomenda medidas para reparo ou substituição, propõe melhorias como substituição de materiais e encaminha problemas e sugestões para estudo da Engenharia.

Para efeito deste trabalho as funções, ou domínios, que agem no sistema de produção são a Operação, que inclui as gerências de Produção e de Transferência e Estocagem, a Engenharia, que abrange as gerências Engenharia 1 e Engenharia 2, e a Manutenção, onde estão as gerências de Manutenção e de Inspeção de Equipamentos.

\subsection{O CASO DA FERTILIZANTES}

Essa organização é uma das unidades industriais de uma das empresas fabricantes de produtos para fertilizantes no Brasil. Trata-se de empresa de grande porte, com capital predominantemente multinacional. O controle acionário é dividido entre grandes empresas do ramo de fertilizantes e do ramo petroquímico. A unidade estudada possui perto de quatrocentos empregados próprios. Há ainda empregados de empresas contratadas.

O processo de produção dessa unidade industrial é divido segundo as duas linhas de produtos fabricados: produtos nitrogenados e produtos fosfatados. Os clientes são fabricantes de fertilizantes, que utilizam o produto da Fertilizantes como matériaprima e empresas químicas e petroquímicas, que adquirem matérias-primas e insumos para seus processos. O Brasil é importador desses produtos, o que faz com que a fábrica trabalhe sempre pressionada por volume de produção. A figura 4.3 mostra um fluxograma esquemático do processo de produção.

$\mathrm{Na}$ estrutura organizacional atual, representada na figura 4.4, quatro gerências setoriais são responsáveis pelas funções objeto desta pesquisa. 
A gerência setorial de engenharia abrange a atividade de engenharia de processo, desempenhada por um grupo de engenheiros que responde diretamente ao gerente da atividade. Além das atividades de acompanhamento dos processos de fabricação e assessoria técnica à produção, esse grupo elabora a parte de processo dos projetos de modificações e melhorias dos processos produtivos.

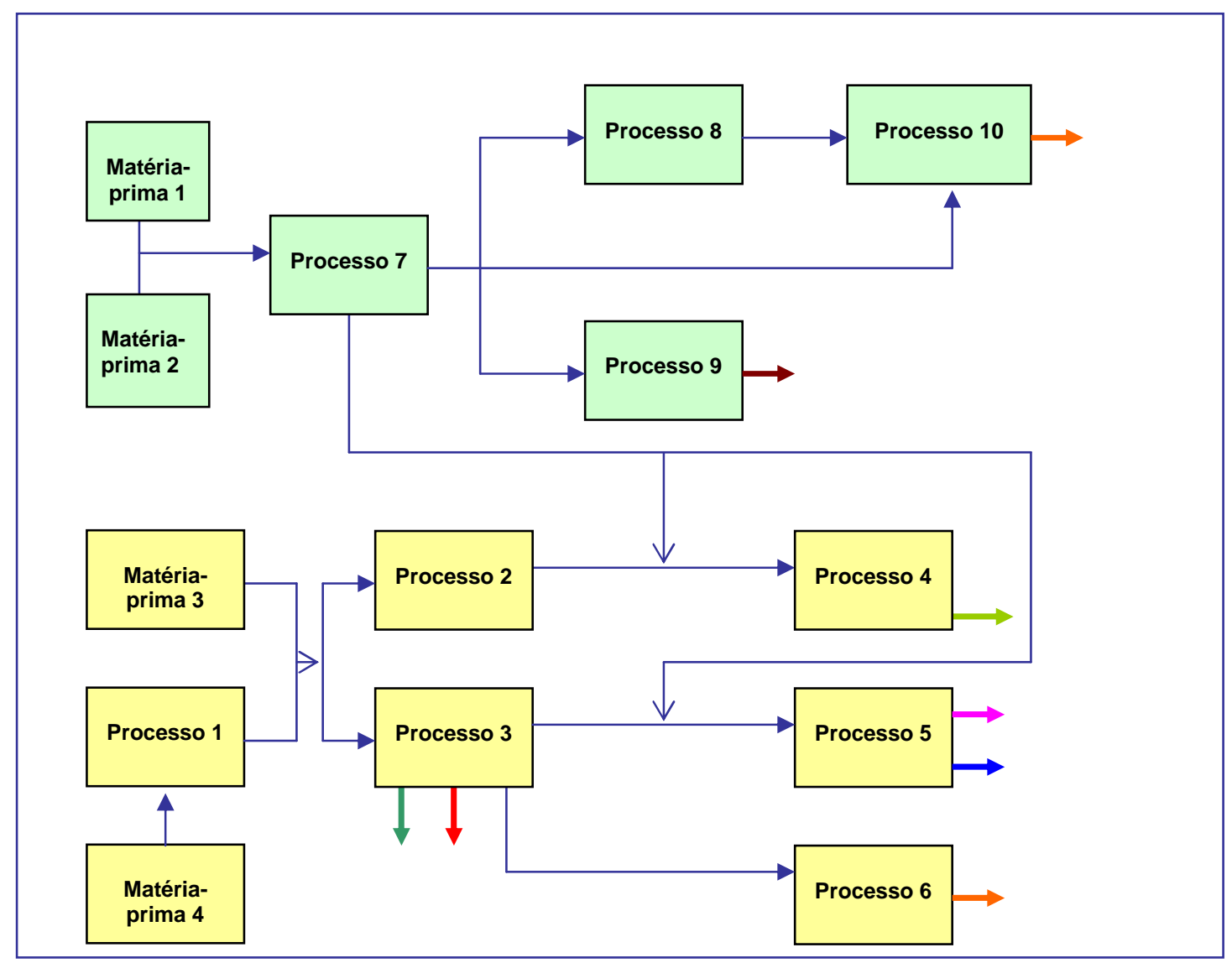

Fig. 4.3 - Fluxograma simplificado de produção da Fertilizantes. Fonte: adaptado pelo autor da página da empresa na internet. 


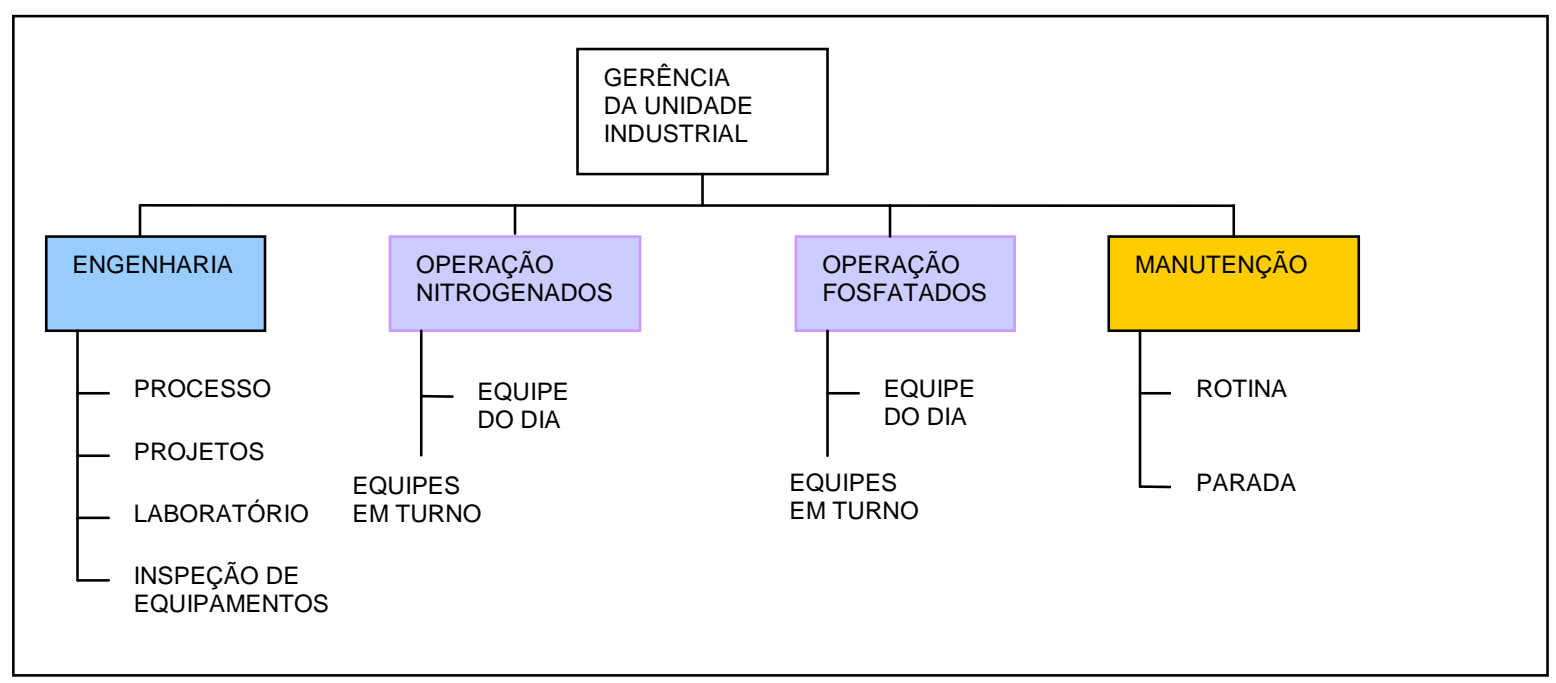

Fig. 4.4 - Organização estrutural do sistema de produção da Fertilizantes. Elaborado pelo autor.

A chamada equipe de projetos é encarregada do desenvolvimento e detalhamento dos citados projetos de modificações e melhorias nas demais especialidades da engenharia (mecânica, elétrica etc.). Essa equipe é constituída por engenheiros e projetistas e conta com um supervisor. No caso desses recursos serem insuficientes para dar conta da carteira de projetos aprovada, parte dos projetos é contratada de terceiros.

Os projetos de grande porte são desenvolvidos e executados por um órgão corporativo, mas o pessoal da engenharia da fábrica participa dos projetos, representando a visão da unidade industrial e contribuindo com o projeto pelo aporte do conhecimento dos processos e particularidades da unidade.

Duas outras atividades foram incorporadas à gerência de engenharia: a inspeção de equipamentos e o laboratório. A primeira consiste na execução de testes, inspeções e emissão de pareceres sobre a integridade física dos equipamentos, com emissão de relatórios à Operação e à Manutenção indicando a necessidade de reparos ou aprovando a condição dos equipamentos para funcionamento. Embora alocada na estrutura da Engenharia, para efeito desta pesquisa essa atividade está mais diretamente relacionada à função Manutenção, a exemplo do que foi discutido no caso da Refinaria.

O laboratório realiza análises e ensaios químicos e físicos para medir as propriedades das matérias-primas, produtos intermediários e produtos finais. Além de fornecer dados para controle dos processos para a Operação e a Engenharia de 
processo, essas análises e ensaios certificam a qualidade dos produtos para entrega aos clientes.

A Operação está dividida em duas gerências setoriais, uma para cada linha de produtos da fábrica. A gerência de fosfatados também é encarregada de operar os sistemas de utilidades (geração de vapor, tratamento de água, fornecimento de ar comprimido etc.). As duas gerências setoriais possuem equipes que operam os sistemas de fabricação em turnos de revezamento e equipes em horário administrativo que dão suporte ao gerente setorial, tratam de demandas de manutenção e atuam junto à Engenharia. Nos turnos há um supervisor para cada gerência operacional e nas equipes do horário administrativo, os técnicos de operação são os principais responsáveis pelo contato com a área de Manutenção e participam de atividades com a Engenharia.

Uma diferença encontrada na atuação das duas gerências setoriais da Operação é o modo como tratam as atividades de Manutenção menos complexas. Uma delas solicita todos os serviços necessários à Manutenção e atua junto a ela para alterar a programação de serviços quando há algum reparo que necessite ser feito com urgência. A outra gerência mantém uma equipe de pronto atendimento de serviços de manutenção sob supervisão direta do técnico de operação, que integra a equipe de operação em horário administrativo, e encaminha para programação da Manutenção os serviços mais complexos, de maior porte e os que podem aguardar por um prazo maior a ocasião da execução. Enquanto esta alega obter mais agilidade nos reparos, a outra gerência de operação afirma que os prazos de reparo Ihe atendem e assim não desvia o foco e nem consome tempo do técnico de operação.

A gerência setorial de manutenção divide suas atividades em dois tipos, com equipes distintas para cada uma. O primeiro tipo são os serviços do dia-a-dia, que inclui reparos programados, rotinas de manutenção e atendimento a situações não previstas. Técnicos de manutenção e trabalhadores de diferentes especialidades (mecânicos, eletricistas, soldadores e outros) realizam esse trabalho. O segundo tipo são as paradas programadas de inspeção e manutenção, planejadas com antecedência. Pessoal próprio e pessoal de terceiros realizam essa atividade, tanto na fase de planejamento como na fase de execução. Há também um órgão corporativo, portanto fora da estrutura da unidade industrial, mas com pessoas 
localizadas na fábrica, que analisa o desempenho e propõe políticas de manutenção para a empresa. 


\section{ANÁLISE DOS DADOS}

A fim de interpretar os dados levantados em cada um dos casos estudados, de modo que a análise desses dados se constitua em referência para discussão e construção (ou revisão) de uma teoria de projetos organizacionais, os mesmos foram tabulados a partir das entrevistas realizadas nas empresas estudadas e dos documentos consultados, que incluem procedimentos escritos e formulários.

Os dados são mostrados de forma consolidada, em quadros, para cada variável de pesquisa e para cada caso, classificados em convergentes e divergentes. Os dados convergentes são aqueles em que situações verificadas nos diferentes casos expressam similaridades para dada variável pesquisada. Os dados divergentes são aqueles em que, para uma mesma variável de pesquisa, as situações mostram diferenças de caso para caso. Incluem-se também nessa classificação dados identificados em apenas um dos casos estudados. Esse método de análise segue 0 que foi exposto no Capítulo 3 - Metodologia de Pesquisa. Será dada ênfase para os dados que evidenciem distúrbios para que cada domínio possa atender de forma integrada as necessidades dos demais domínios e do sistema de produção, tendo em vista que dentre os principais objetivos do projeto organizacional estão a redução da propagação dos distúrbios e a dotação à organização da capacidade de lidar com as variações, conforme o conceito de dirigibilidade. As situações em que se constata que as fronteiras entre os segmentos organizacionais envolvidos não são fixas, isto é, se movem fugindo à concepção de segmentação da estrutura organizacional e há uma intersecção das atividades dos domínios organizacionais - fronteiras interpenetrantes - serão objeto de discussão neste e no próximo capítulo.

Os quadros, que vão da página 75 à página 85 , servem para organizar e apresentar os dados. As considerações acerca deles são feitas no texto imediatamente após os quadros. 


\subsection{APRESENTAÇÃO DOS DADOS}

\section{TABELA 5.1 VARIÁVEL DE PESQUISA 1: IDENTIFICAÇÃO E RELEVÂNCIA DAS INTERFACES ENGENHARIA / PRODUÇÃO / MANUTENÇÃO (CONTINUA)}

Variabilidades do sistema, eventos e interfaces; soluções de problemas e melhorias; projetos; controle do sistema de produção; curto $X$ longo prazo; rotina $X$ eventos significativos.

\section{Dados Convergentes:}

Engenharia atua junto à Operação quando constata desvios nas variáveis do processo. Muitas vezes são detalhes sutis do processo, ainda não percebidos pela Operação, e a atuação é com foco na prevenção de falhas.

Operação percebe variações não esperadas em variáveis do processo e no funcionamento dos equipamentos e aciona Manutenção para quantificar e identificar possíveis problemas em equipamentos.

Engenharia estuda parâmetros de processo em face de situações da produção e recomenda à Operação os valores de ajuste dos parâmetros. Também estuda problemas em equipamentos e, muitas vezes, constata que um problema inicialmente tido como defeito do equipamento (mecânico ou elétrico, por exemplo), na realidade é causado pelo seu funcionamento fora das condições de projeto.

Engenharia especifica tecnicamente peças e equipamentos para Operação e Manutenção e quantifica e orça insumos para a Operação.

Operação solicita serviços à Manutenção e os prioriza. Operação prepara equipamento, Manutenção executa serviço, Operação recebe ou recusa o equipamento.

Engenharia e Manutenção muitas vezes têm visões diferentes sobre prioridades a serem dadas às ações da Engenharia: assistências técnica (à Manutenção), estudos de melhorias e projetos das instalações de produção.

Há participação da Operação e da Manutenção no desenvolvimento de projetos pela Engenharia. 


\section{TABELA 5.1 VARIÁVEL DE PESQUISA 1: IDENTIFICAÇÃO E RELEVÂNCIA DAS INTERFACES ENGENHARIA / PRODUÇÃO / MANUTENÇÃO (CONTINUAÇÃO)}

\section{Dados Divergentes:}

Foi destacado em uma das empresas pesquisadas que diferenças de objetivos entre os segmentos são uma das dificuldades nas interfaces. Um dos entrevistados deu sua interpretação dessa divergência de objetivos: Engenharia - realizar projetos; Manutenção - reduzir custos; Operação - buscar lucro nas operações, nem sempre por meio da redução de custos.

Apesar dessa diferença de objetivos não ter sido explicitamente destacada na outra empresa, situações semelhantes podem ser observadas, como no caso apontado a seguir do pronto atendimento de manutenção pela Operação.

Em uma das duas gerências setoriais que formam a estrutura organizacional da Operação da Fertilizantes os serviços de pronto-atendimento de reparos, que são serviços de pequeno porte e execução rápida são realizados por uma equipe de manutenção que fica à disposição da Operação, e se reporta diretamente ao técnico de operação dessa gerência. Na outra gerência setorial da Operação não há equipe à disposição, todos os reparos são solicitados à gerência de manutenção, que realiza os trabalhos conforme programação. $O$ gerente que mantém a equipe de pronto-atendimento explicou que assim consegue maior agilidade e direciona melhor o atendimento para o que considera serem suas necessidades imediatas. Entretanto, o gerente e engenheiro da área da Manutenção vêem nessa prática perda de produtividade desses recursos para manutenção por ficarem à disposição ao invés de serem incluídos no sistema de planejamento e programação de manutenção. Referiram-se também que consideram um aproveitamento inadequado da capacidade do Técnico de Operação, que despende boa parte do seu tempo com o gerenciamento dos recursos à disposição, desviando o foco das atividades de sua função.

Apenas na Refinaria foi destacada a interface nos projetos de automação de processo, que envolvem Engenharia, Operação e Manutenção. Também há forte interface na operação desses sistemas, para solução de problemas no controle avançado e realização de ajustes no controle dos processos. 


\section{TABELA 5.1 VARIÁVEL DE PESQUISA 1: IDENTIFICAÇÃO E RELEVÂNCIA DAS INTERFACES ENGENHARIA / PRODUÇÃO / MANUTENÇÃO (CONCLUSÃO)}

Uma explicação possível dada pelos próprios entrevistados é que a RPBC possui grau bem maior de automação, por isso essa interface não foi destacada pelos entrevistados da Fertilizantes. Porém, outros aspectos das interfaces entre os três domínios relativas a projetos são apontados ao longo da pesquisa, como será visto adiante.

\section{TABELA 5.2 VARIÁVEL DE PESQUISA 2: NATUREZA DAS INTERFACES (CONTINUA)}

Situações não rotineiras: como são tratadas? Quem assume a liderança? Que formas de organização são adotadas? O que não funciona bem? O que funciona bem? Situações rotineiras: há estruturas para essas ocasiões? Quem lidera e decide? Por quê? Quais os espaços e fóruns criados? Com relação ao ciclo dos processos (ciclo longo $\mathrm{X}$ ciclo curto): há diferenças no tratamento?

\section{Dados Convergentes:}

Uma forma organizacional bastante utilizada na análise de eventos não previstos na produção é o grupo multifuncional, designado formalmente ou não, com participação de pessoas da Operação, Engenharia e Manutenção. Na maioria das vezes, a Operação é a responsável por controlar a implantação das ações recomendadas por esses grupos para resolver problemas e evitar sua repetição. Alguns modos de dar tratamento formal ao problema nesses grupos são através de sistemas de gestão tipo ISO9001 e ISO14001, onde os eventos são registrados e tratados como nãoconformidades do sistema de gestão, e o uso do MASP - Método de Análise e Solução de Problemas, oriundo da Qualidade Total.

Porém, foi destacado que nem sempre há concordância das pessoas que não participaram dos grupos de análise, como operadores e técnicos de manutenção das áreas onde os problemas ocorreram, mas que não foram designados para participar dos grupos de trabalho, com as ações adotadas para corrigir os problemas ocorridos e evitar a sua repetição. 


\section{TABELA 5.2 VARIÁVEL DE PESQUISA 2: NATUREZA DAS INTERFACES (CONTINUAÇÃO)}

Na parte das rotinas, dois grupos de atividades foram citados nos casos estudados. Em uma dessas seqüências de atividades, operadores abrem Ordens de Manutenção ou Solicitações à Manutenção. Numa etapa posterior, considerando a carteira de solicitações, são discutidas prioridades, realizados planejamento e programação dos trabalhos. Essa etapa é feita pelas equipes de continuidade operacional, no caso da Refinaria, e pelos técnicos de operação e técnicos de manutenção, no caso da Fertilizantes. A ela se seguem etapas de execução e aceitação dos serviços.

Outra seqüência de atividades é relativa à solicitação de projetos e estudos à Engenharia, a definição de prioridades dessas solicitações e elaboração dos estudos e projetos pela Engenharia com participação dos demais segmentos. As principais dificuldades apresentadas são consenso sobre as definições de prioridades acerca dos estudos e projetos a serem realizados e participação da Operação e da Manutenção nos estudos e projetos da Engenharia. Quanto ao problema da participação na fase de elaboração dos projetos, a Engenharia aponta que os demais segmentos nem sempre fazem seus comentários acerca dos projetos, embora chamados a isso.

Por outro lado, Operação e Manutenção afirmam que em razão da pressa de concluir os projetos, nem sempre lhes é dada a oportunidade de fazer comentários nos projetos, o que faz com que suas necessidades não sejam plenamente atendidas (por exemplo, especificação nos projetos de componentes que não são os mais adequados do ponto de vista de manutenção).

Em todas as situações acima, tanto na ocorrência de eventos como nas atividades de manutenção e de projetos, os técnicos de operação têm papel muito importante na interface entre Engenharia, Manutenção e os operadores (“elo").

Rotina: as empresas pesquisadas criaram sistemáticas para solicitação de elaboração de projetos à Engenharia, onde são previstas a descrição e justificativa da necessidade e uma fase de priorização de modo a formar uma carteira de projetos a serem elaborados, uma vez que as solicitações excedem a capacidade de atendimento. 


\section{TABELA 5.2 VARIÁVEL DE PESQUISA 2: NATUREZA DAS INTERFACES (CONCLUSÃO)}

\section{Dados Divergentes:}

Enquanto na Refinaria foi ressaltado o problema das diferenças de visões entre grupos diferentes, como do pessoal das equipes de continuidade operacional (ECO) que trabalham em horário administrativo e equipes de turno, na Fertilizantes foi ressaltada pelos entrevistados a facilidade de contato direto entre engenheiros, gerentes e técnicos de operação e de manutenção, em razão da estrutura organizacional ser relativamente pequena.

A questão da adoção de formalismo nas interfaces, sejam fixas ou móveis, foi abordada nos dois casos enfocando situações diferentes. Foi destacado por entrevistados na Refinaria que em situações não rotineiras, como a ocorrência de problemas que ocasionam perda de produção, melhoram as interfaces, pois se agilizam as formalidades constantes dos procedimentos. Na Fertilizantes foi mostrado pela Engenharia o procedimento para formalização e controle das consultas feitas à Engenharia, que determina que as consultas devem ser encaminhadas em formulário próprio, como algo bom, por disciplinar essas solicitações.

\section{TABELA 5.3 VARIÁVEL DE PESQUISA 3: PARALELIZAÇÃO E SEGMENTAÇÃO} DAS ATIVIDADES ENTRE OPERAÇÃO, MANUTENÇÃO E ENGENHARIA (CONTINUA)

Quem controla ou executa o que? Incorporação versus separação de engenheiros e especialistas da manutenção aos órgãos de produção: qual a estrutura adotada? Por quê? Agilidade na resposta a variabilidades do sistema de produção; maior transferência de conhecimento entre os profissionais de cada uma dessas áreas; deterioração dos trabalhos e da visão de médio e longo prazo em razão da priorização dos problemas de curto prazo; perda de especialização e de conhecimento dos engenheiros em razão do foco no curto prazo. 


\section{TABELA 5.3 VARIÁVEL DE PESQUISA 3: PARALELIZAÇÃO E SEGMENTAÇÃO DAS ATIVIDADES ENTRE OPERAÇÃO, MANUTENÇÃO E ENGENHARIA (CONTINUAÇÃO)}

\section{Dados Convergentes:}

Engenharia tem estrutura própria, separada da Operação e da Manutenção.

Operação controla as unidades de produção durante 24h. A Engenharia e a Manutenção são acionadas para avaliar, estudar e atuar junto à Operação em razão de desvios e mudanças na produção.

As pessoas diretamente envolvidas nas ocorrências de falhas (operadores, eletricistas, mecânicos etc) dificilmente participam dos grupos de trabalho constituídos para analisá-las. Na Refinaria foi constatada a possível participação de técnicos de manutenção e operadores mais experientes nos grupos de trabalho, que não são necessariamente os que estavam trabalhando na ocorrência do evento. $\mathrm{Na}$ Fertilizantes, foi relatado que não é usual a participação de operadores nos grupos de solução de problemas. A definição da composição desses grupos é feita pelos gerentes.

Participação da Operação no desenvolvimento dos projetos de modificações é baixa, apesar de haver sistemáticas de projetos que prevêem essa participação nos dois casos estudados. Em uma das empresas foi dito explicitamente por um dos entrevistados que o procedimento escrito para projetos foi criado para comprometer a Operação e a Manutenção com os projetos durante o seu desenvolvimento. Entretanto, foi constatado que em projetos de grande porte há o deslocamento de pessoas da Manutenção e Operação de suas atividades normais para compor as equipes dos projetos.

\section{Dados Divergentes:}

$\mathrm{Na}$ Fertilizantes há um procedimento formal definindo quais variáveis de processo são acompanhadas pela Engenharia e em qual periodicidade. Na Refinaria, embora haja o entendimento dos papéis de cada um, foram relatadas situações em que essa divisão de trabalho nem sempre é bem definida. 


\section{TABELA 5.3 VARIÁVEL DE PESQUISA 3: PARALELIZAÇÃO E SEGMENTAÇÃO DAS ATIVIDADES ENTRE OPERAÇÃO, MANUTENÇÃO E ENGENHARIA (CONCLUSÃO)}

Um exemplo dado por um dos entrevistados refere-se à divisão do trabalho em grupos multifuncionais: se Engenharia e Operação, e em alguns casos também a Manutenção, olham tudo, não há divisão, logo a chance de alguma coisa não ser vista é grande. Apesar dessa afirmação, das entrevistas realizadas foi possível colher dados que mostram como é a divisão do trabalho entre os domínios, demonstrada nas frases abaixo:

Engenharia de processo é mais voltada para o novo e pouco conhecido e enxerga a unidade como um todo. Operação raciocina mais com histórico.

Manutenção acompanha equipamentos e Engenharia trata de problemas críticos e projetos. Excesso de dedicação aos projetos inibe atendimento às necessidades apontadas pela Manutenção.

\section{TABELA 5.4 VARIÁVEL DE PESQUISA 4: DIFERENCIAÇÃO DA EXECUÇÃO (CONTINUA)}

Separação de atividades entre o pessoal da Operação, como preparação e execução: essa separação se estende aos outros domínios, ou seja, algumas dessas atividades são realizadas pelos outros domínios? Idem para a Manutenção e para a Engenharia.

\section{Dados Convergentes:}

Engenharia de processo estuda comportamento das variáveis de operação dos processos. Muitas vezes a Engenharia recorre à Manutenção para supervisionar ou fiscalizar no campo a implantação de projetos.

Engenharia de processo elabora procedimentos para a Operação, quando eles exigem conhecimentos técnicos de engenharia. 


\section{TABELA 5.4 VARIÁVEL DE PESQUISA 4: DIFERENCIAÇÃO DA EXECUÇÃO (CONCLUSÃO)}

Operação e Manutenção participam junto com a Engenharia de Automação do desenvolvimento, projeto e implantação de sistemas automatizados de controle de processo. Essa condição foi observada apenas na Refinaria, que possui um grau de automação maior. Entretanto, foi verificada a ocorrência de situações semelhantes em outros tipos de projetos, nos dois casos estudados.

\section{Dados Divergentes:}

Não foram verificados.

\section{TABELA 5.5 VARIÁVEL DE PESQUISA 5: ESPECIALIZAÇÃO DA EXECUÇÃO}

Limites de conhecimento do processo de produção que são supridos pela Engenharia e pela Manutenção; atividades da produção que, por necessidade de conhecimento, são alocadas a outros subsistemas, com a participação da Engenharia e da Manutenção.

\section{Dados Convergentes:}

Para definição de parâmetros nos sistemas de automação, a Operação leva em conta sensibilidade e prática e a Engenharia utiliza conhecimentos de matemática, física e química.

A Engenharia de processo elabora procedimentos para a Operação, quando eles exigem conhecimentos técnicos de engenharia.

\section{Dados Divergentes:}

Há limites de conhecimentos dos operadores sobre controle avançado e na interpretação de valores de variáveis dos processos (conhecimento da Engenharia). Há ainda limitação de conhecimentos para testes e ajustes dos equipamentos e instrumentos dos sistemas automatizados (conhecimentos do pessoal de instrumentação). A Engenharia e a Manutenção (instrumentação) participam dessas atividades suprindo esses conhecimentos. Esse dado foi considerado divergente por não ser possível confrontá-lo com o caso da Fertilizantes. 


\section{TABELA 5.6 VARIÁVEL DE PESQUISA 6: SEPARAÇÃO DAS FUNÇÕES DE EXECUÇÃO E CONTROLE E ESPECIALIZAÇÃO DO CONTROLE (CONTINUA)}

Qual é o papel de cada uma das áreas (Operação, Manutenção e Engenharia) na controlabilidade do sistema de produção? Há papel preponderante ou liderança de alguma dessas áreas na questão da controlabilidade? Quais os limites para a atuação dos operadores na controlabilidade? Qual é a "autoridade" da Manutenção e da Engenharia sobre o sistema de produção sob a ótica da controlabilidade? Como é a atuação da engenharia e da manutenção em relação à autoridade e autonomia dos operadores sobre o sistema de produção? Há problemas nessa interface? SDCD e outros sistemas automatizados, incluindo controles avançados: como são tratados? Pode-se dizer que o engenheiro também opera o sistema por meio do controle avançado? Como são divididas as responsabilidades? Como é feita a passagem de conhecimentos entre essas áreas? Descrever e analisar como ocorre o tratamento dos eventos, considerando o papel das três áreas e de outras que porventura venham a participar.

\section{Dados Convergentes:}

As decisões finais sobre mudanças nos parâmetros operacionais são do gerente da Operação, mesmo quando há estudo da Engenharia. Formação de equipes multidisciplinares para embasar "decisões polêmicas". Em situações mais complexas de problemas de equipamentos a decisão fica com a Engenharia.

Operação recorre à Engenharia quando o problema já está instalado, não antecipa.

A liderança nas ações para pilotar o sistema de produção (ações de controle sobre os processos de produção) pode passar da operação para outros domínios, conforme a situação ou assunto (eventos).

A definição de objetivos de produção, no curto e médio prazos, é feita pela Programação de Produção (do domínio da Engenharia no caso da RPBC e corporativa no caso da Fertilizantes) em conjunto com Operação e Engenharia de Processo. 


\section{TABELA 5.6 VARIÁVEL DE PESQUISA 6: SEPARAÇÃO DAS FUNÇÕES DE EXECUÇÃO E CONTROLE E ESPECIALIZAÇÃO DO CONTROLE (CONCLUSÃO)}

Participação dos operadores nas discussões e decisões pertinentes à dirigibilidade do sistema de produção é limitada, independentemente de outras decisões de cunho organizacional, pelo regime de turno e distâncias físicas entre as plantas e escritórios.

Operação relata à Manutenção situações identificadas dos equipamentos e viceversa, Manutenção relata à Operação situações do processo identificadas ao examinar os equipamentos.

É papel do técnico de operação discutir as mudanças no processo propostas pela Engenharia, com ela própria e com os operadores.

As solicitações de projetos à Engenharia devem ter prioridades definidas pela Operação, tendo em vista a limitação de recursos para elaboração dos projetos. As entrevistas identificaram que não há concordância plena ente o três domínios quanto ao atendimento às necessidades mais importantes.

\section{Dados Divergentes:}

Em relação ao controle avançado, o grau de participação dos operadores nas decisões depende do interesse e do conhecimento de cada operador.

A engenharia de automação atua na operação do sistema de produção, por meio dos sistemas de controle automatizados, para implementar metas de produção, ligadas à otimização dos processos.

Atuação das equipes de continuidade operacional - ECO foi considerada um ponto forte da organização na Refinaria. Já na Fertilizantes, a Manutenção considera equipe de pronto atendimento à disposição da Operação uma prática improdutiva.

Na Fertilizantes, a comunicação aos operadores sobre solicitações de modificações e melhorias feitas por eles que não são atendidas é deficiente. Na Refinaria, embora o problema exista, foi relatado por operadores e técnicos de operação que estes promovem essa comunicação. 
TABELA 5.7 VARIÁVEL DE PESQUISA 7: DIFERENCIAÇÃO DO CONTROLE

Há diferenças de nível de controle em relação ao sistema de produção (estratégico, tático e operacional)? Como se situam a Operação, Engenharia e Manutenção em relação a esses níveis?

Dados Convergentes:

A Engenharia atua predominantemente no nível tático, enquanto a Operação atua no nível operacional. Enquanto a engenharia de processo se concentra no acompanhamento das variáveis a médio e longo, o acompanhamento da Operação é sobre as variações imediatas dos processos.

Dentre as ocasiões de interação entre os dois ciclos de controle (tático e operacional) destacam-se as reuniões diárias matinais de Produção, onde são relatados fatos relevantes ocorridos desde o dia anterior e feito planejamento das ações imediatas a serem tomadas.

Dados Divergentes:

Não foram verificados. 


\subsection{ANÁLISE DE DADOS: DISCUSSÃO}

A partir dos dados mostrados nos quadros acima, são feitas as considerações que se seguem:

\subsubsection{Quanto às principais interfaces identificadas - variável de pesquisa 1 (dados} apresentados na tabela 5.1 das páginas 75 a 77 ):

O primeiro problema apresentado foi diferença de objetivos na atuação de cada um dos segmentos, ou como expressou um gerente da Operação da Refinaria, "a existência de objetivo maior frente a objetivos particulares". Essas diferenças aparecem em situações como a Manutenção perseguir uma redução de custos na sua atividade limitando recursos quando a Operação entende que os recursos de Manutenção deveriam ser mais abundantes, atendendo uma carteira maior de serviços ou com intervenções mais imediatas e mais abrangentes para reparar defeitos. Por exemplo, a falha de um instrumento que mede certa variável de processo, como pressão ou temperatura em um equipamento pode não justificar a escalação de recursos em horário extraordinário, se os operadores tiverem outra forma de obter esses valores para o controle do processo. Entretanto, o pessoal de Operação pode julgar a leitura direta daquele instrumento mais conveniente para a forma com que executam seu trabalho de controle do processo e entenderem vantajosa a alocação de recursos imediatos da Manutenção para fazer o reparo.

$\mathrm{Na}$ Fertilizantes, também foram identificadas situações relacionadas ao mesmo tipo de problema. Uma das gerências da Operação criou equipe de pronto-atendimento de manutenção. Esse grupo de profissionais trabalha sob a supervisão direta de um técnico de operação da área. Entretanto pessoas ligadas à Manutenção relataram que consideram essa prática muito improdutiva, e mesmo a outra gerência de operação existente na fábrica prefere não ter a equipe de pronto-atendimento. Nesta outra área da Operação, todos os serviços de manutenção são solicitados à Manutenção e a realização desses trabalhos é programada dentro da carteira de serviços para aquela área operacional. Enquanto o gerente de operações que mantém a equipe de manutenção sob o seu controle entende que ganha agilidade, os demais entendem que os recursos seriam melhor aproveitados se seguissem uma programação sistemática, 
como costuma acontecer na Manutenção. A coexistência das duas formas organizacionais na mesma fábrica pode indicar estilos gerenciais diferentes dos gerentes da Operação, sendo um deles mais centralizador. Mas retrata também a questão de objetivos de desempenhos diferentes, frente aos objetivos globais da produção.

Também quanto à Operação e à Manutenção em relação à Engenharia observaram-se conflitos, relacionados principalmente às diferenças de ciclo. Reproduzindo aqui o ponto de vista de diversos entrevistados, enquanto a Engenharia trabalha em ciclos mais longos, a Operação e a Manutenção têm foco maior em trabalhos de curto prazo. Assim, solicitações de serviços como consultas técnicas e a elaboração de pequenos projetos, quando atendidas, podem implicar na interrupção de projetos de maior prazo. Essa opção costuma trazer certo desconforto aos engenheiros e técnicos da Engenharia empenhados nos projetos. O não atendimento, por outro lado, gera reclamações dos profissionais da Operação e da Manutenção, que vêm no não atendimento às solicitações a postergação da solução de problemas do sistema de produção.

Para lidar com essa situação, tanto a Refinaria como a Fertilizantes criaram sistemáticas para disciplinar e sistematizar a solicitação de estudos e projetos de engenharia, incluindo a determinação de prioridades entre as solicitações, pela Operação ou com a participação dela. A Fertilizantes adotou também sistemática para formalizar e controlar as solicitações de informações técnicas à Engenharia. Essas sistemáticas incluem bancos de dados para cadastro das solicitações de estudos e projetos feitas à Engenharia, formulários de encaminhamento com campos para que a Operação atribua escalas de prioridade e reuniões para rediscussão das prioridades, pois costuma haver mais de uma solicitação com a mesma escala de prioridade.

Ainda assim, em boa parte das vezes não há consenso entre os três segmentos sobre a ordem de prioridades e, consequentemente, os prazos de elaboração dos estudos e projetos, uma vez que os recursos humanos e financeiros são sempre fatores limitantes.

Outra situação que mereceu atenção dos entrevistados foi a participação da Manutenção e da Operação na elaboração dos projetos de engenharia. É importante destacar que são projetos de modificações no sistema de produção existente, grande parte das vezes de pequeno porte, mas que alteram o seu funcionamento e o 
desempenho dos equipamentos. Não houve convergência dos problemas citados. Houve casos de pessoas da Engenharia relatando que devido à dedicação ao trabalho operacional de curto prazo os representantes designados pela Operação e pela Manutenção em muitas ocasiões deixam de participar do desenvolvimento dos projetos, quando deveriam fazer observações e emitir comentários. Segundo esses engenheiros, quando os projetos não são analisados e comentados por profissionais das demais funções o resultado final dos projetos pode ficar comprometido quanto ao atendimento às necessidades das próprias Operação e Manutenção. Essa necessidade de ter os comentários dos profissionais dos outros domínios, manifestada pelos engenheiros, serve para demonstrar a importância de se integrar conhecimentos das diferentes funções que intervém no sistema de produção.

Da mesma forma, profissionais da Manutenção e da Operação relataram que nem sempre os projetos elaborados pela Engenharia estão de acordo com as suas necessidades. Por exemplo, a Manutenção padroniza certos tipos de componentes como relés - que na sua experiência apresentam melhor desempenho, maior facilidade de substituição etc, e os projetistas especificam componentes em desacordo com essa padronização. Essa desconformidade não é percebida se o projeto não for apreciado pelo pessoal de manutenção elétrica na sua fase de elaboração (ou talvez a decisão de padronizar não seja adequadamente informada à Engenharia).

Algumas situações de interface, mereceram menção dos entrevistados, não por serem consideradas problemáticas, mas pela sua importância: o planejamento e programação de trabalhos de manutenção, a realização dessa manutenção, que inclui a preparação dos equipamentos pela Operação, a realização dos trabalhos pela Manutenção e o recebimento dos equipamentos pela Operação ao término dos serviços de reparo. No primeiro caso, especialmente, a interface foge ao esquema tradicional de fronteira fixa, em que a coordenação entre os segmentos envolvidos diz respeito à seqüência de atividades e tempos de intervenção. O planejamento de uma intervenção de manutenção pode exigir a integração de diferentes conhecimentos dos domínios organizacionais envolvidos. Nessa situação, a coordenação do trabalho inclui a análise conjunta do problema e decisões compartilhadas, entre Operação e Manutenção, às vezes requerendo inclusive o apoio da Engenharia, movendo as fronteiras entre as funções e tornando-as interpenetrantes. Por exemplo: analisar os riscos existentes na intervenção (reparos com solda em equipamento ou em tubo, manutenção de 
instrumentos de controle de processo etc.) e definir as tarefas e medidas de controle de modo que o trabalho possa ser realizado respeitando a segurança das pessoas e o meio-ambiente e afetando ao mínimo a continuidade da produção. Cabe lembrar que em razão das matérias-primas e produtos tóxicos e inflamáveis processados nas indústrias estudadas, suas atividades são consideradas de risco.

\subsubsection{Quanto à natureza das interfaces - variável de pesquisa 2 (dados apresentados na tabela 5.2 das páginas 77 a 79$)$ :}

Essa variável de pesquisa procura identificar diferenças na organização do trabalho entre situações rotineiras e não rotineiras, conforme classificação utilizada por Pava (1983). Neste trabalho, essa classificação considera nas situações não rotineiras o conceito de eventos, incorporando à pesquisa o conceito de evento apresentado por Zarifian (ZARIFIAN e AUBÉ, 1992; VELTZ e ZARIFIAN, 1993). O evento é toda situação que foge à regularidade das operações, incluindo tanto ocorrências indesejadas, como panes em equipamentos e desvios de qualidade de produtos, como acontecimentos planejados, como a implantação de modificações através de projetos de engenharia e a execução de novos procedimentos operacionais.

Um exemplo interessante que inclui mais de um evento numa só ocorrência foi relatado tanto pelo pessoal de Operação como pelo pessoal de Engenharia da Fertilizantes. Um equipamento de grande importância para o processo passou a apresentar deficiências sérias, de causa desconhecida, causando alterações na composição do produto que processa. Várias ações foram tomadas para identificar a causa do problema: análise por grupos multifuncionais com participantes da Operação, Manutenção e Engenharia utilizando técnicas de análise e solução de problemas da Qualidade Total, consultas ao detentor da tecnologia de fabricação utilizada, levantamento dos fluxos internos ao equipamento com uso de aparelho "escaneador" a laser, tudo sem sucesso. A Operação optou então por abrir o equipamento e substituir os recheios internos ${ }^{3}$, uma intervenção não usual que foi realizada pela Manutenção. Nessa ocasião, a Operação apoiada pela Engenharia decidiu aproveitar a ocasião para a instalação de recheios de tipo diferente do especificado no projeto, mais modernos. Após a substituição dos

\footnotetext{
${ }^{3}$ Peças inseridas no interior de equipamentos para causar restrição ao fluxo de gases e promover maior contato entre fluidos, possibilitando a ocorrência de reações físicas e químicas. Por exemplo, a transferência de massa de uma substância contida no fluxo de gases para outro fluido.
} 
recheios pela Manutenção, durante a realização dos procedimentos de preparação do equipamento para voltar a funcionar, pela Operação, foi necessário realizar um procedimento não usual, de apassivação ${ }^{4}$. Tendo em vista tratar-se de situação não trivial que requeria conhecimentos técnicos que fugiam daqueles de domínio da Operação, esse procedimento foi elaborado pela Engenharia e realizado pela Operação sob coordenação da Engenharia, com apoio da Manutenção.

Percebe-se desse exemplo, e de outros relatados nessa e nas outras empresas pesquisadas, que não há uma forma de organização do trabalho permanente para os eventos, mas soluções organizacionais que se estabelecem caso a caso, como na realização do procedimento de apassivação do equipamento da Fertilizantes, onde os engenheiros de processo trabalharam em turnos para acompanhar e fazer a coordenação técnica da execução do procedimento pelos operadores. Percebe-se aí uma divisão de responsabilidades, a Engenharia pela elaboração e pela orientação técnica e a Operação pela execução, mas, ao mesmo tempo, um compartilhamento da responsabilidade pelo sucesso desse trabalho. Essa é uma constatação importante, pois difere da divisão de trabalho usual, onde se definem fronteiras de atuação e de responsabilidades. Ou seja, trata-se de caso de fronteiras móveis e interpenetrantes.

Ainda, pode se notar que a liderança ao longo dos diversos eventos desse ocorrido mudou várias vezes de um domínio para o outro. É interessante registrar a observação de um supervisor de manutenção entrevistado, da Refinaria, que observou que no atendimento a eventos de emergências (as emergências operacionais na linguagem da Refinaria são ocorrências de interrupção da produção não previstas, decorrentes de falhas de equipamentos, dentre outras causas possíveis) o trabalho fica mais fácil, pois as formalidades (autorizações, análises de riscos, processos de compras) são feitas de forma mais ágil e há mais disponibilidade e cooperação das pessoas dos diversos segmentos.

Do exposto, pode se dizer que algumas características importantes da organização nas situações de eventos são disponibilidades de conhecimentos e habilidades diversos, exercício da liderança conforme os conhecimentos e habilidades necessários a cada momento e mecanismos eficientes de coordenação.

\footnotetext{
${ }^{4}$ Operação para tornar inerte uma substância agressiva. Por exemplo, neutralizar ácido utilizado na limpeza de equipamentos.
} 
Por outro lado, o da rotina, dois temas estiveram bastante presentes nos casos estudados: o das solicitações de estudos e projetos à Engenharia, incluindo a determinação de prioridades e capacidade de atendimento à carteira de solicitações, e o atendimento às necessidades de manutenção, que compreende a elaboração da lista de necessidades, normalmente pela Operação, a determinação da seqüência de atendimento, segundo a prioridade, oportunidade e limitação dos recursos.

No que toca aos estudos e projetos, entrevistados dos três domínios, nas duas empresas pesquisadas, manifestaram haver problemas. Ao mesmo tempo em que a Engenharia alega que a determinação de prioridades pela Operação não é feita de modo satisfatório, ocasionando sobrecarga e dificultando o seu planejamento, tanto a Operação como a Manutenção mostraram-se descontentes com o grau de atendimento às suas necessidades, ou seja, a Engenharia não realiza todos os estudos e projetos que consideram importantes. Uma das causas apontadas foi a limitação dos recursos. Mas em uma das empresas um gerente de Operação considerou como dificuldade adicional a pouca experiência do grupo de Engenharia.

$\mathrm{Na}$ parte relativa aos serviços de manutenção, foram encontradas soluções organizacionais diferentes nos estudos de casos: a Refinaria, através do pessoal entrevistado, mostra-se satisfeita com a experiência das Equipes de Continuidade Operacional - ECO, enquanto a Fertilizantes centra o estabelecimento de prioridades nos técnicos de operação e gerentes de produção. A programação de serviços é feita após o estabelecimento de um consenso destes com o gerente e técnicos de manutenção. Em todos os casos, destacou-se a importância do relacionamento direto entre as pessoas que participam desse processo.

Em particular na Refinaria, foi destacada a importância dos operadores que estão na ECO estabelecerem entendimento com as equipes de turno acerca do planejamento dos trabalhos de manutenção. Faz parte do planejamento uma análise preliminar dos riscos envolvidos no trabalho, com o estabelecimento de medidas para controlá-los, que podem incluir desde o uso de equipamentos de proteção individual a manobras operacionais com interrupção do funcionamento de equipamentos, lavagem e purga de sistemas etc. Essas manobras são efetuadas pelas equipes de turno que respondem pela operação das plantas no momento da execução do trabalho ou nos períodos anteriores a ele. Ocorre que nem sempre os operadores concordam com as medidas estabelecidas, podendo considerá-las tanto desnecessárias e complicadas como 
insuficientes para que o trabalho de manutenção seja executado com segurança. Isso pode ocasionar necessidade de se rever o planejamento, insegurança dos operadores para liberar o início dos trabalhos (emissão da Permissão de Trabalho), demora no início dos serviços etc.

Nesses momentos, tanto no que diz respeito à implantação de projetos como na execução de serviços de manutenção não rotineiros (portanto, embora solicitados e programados dentro de uma rotina pré-estabelecida, podem ser considerados eventos) foi destacado o papel dos técnicos de operação, encarregados de fazer fluir a comunicação de cunho técnico entre os operadores do turno e demais segmentos envolvidos. Essa comunicação é dificultada pelo próprio regime de trabalho: enquanto técnicos e engenheiros trabalham em horário comercial, os operadores trabalham em turnos de revezamento, pela dificuldade em deslocarem-se operadores de suas tarefas operacionais para participar dos estudos e elaborações de planos de intervenção, pela distância física entre áreas etc.

Como já enunciado por Pava (1983), as situações rotineiras permitem a criação de formas organizacionais, procedimentos, designação de responsáveis etc, mais estruturadas e menos mutáveis. Já nas situações não rotineiras, em razão da variação dessas situações, os arranjos organizacionais também são mais variados e tendem a ser menos estruturados. Ficou evidenciado, qualquer que seja a situação, que há necessidade de ser tratada a comunicação com o pessoal operacional que será envolvido em etapas posteriores do trabalho, notadamente o pessoal de Operação, que trabalha em regime de turno. Esse aspecto foi evidenciado na Refinaria. Os entrevistados na Fertilizantes destacaram a facilidade de contato pessoal por ser uma fábrica com poucas pessoas, que ficam relativamente próximas. Entretanto, mesmo lá, foi constatado que os operadores não costumam participar dos grupos de análise e solução de problemas, quando a Operação se faz representar pelos gerentes e técnicos de operação. Essas constatações indicam certa separação entre gerentes, engenheiros e técnicos de maior nível hierárquico do pessoal de execução da Operação e da Manutenção na análise e proposição de soluções dos problemas do sistema de produção. 
5.2.3 Quanto à paralelização e segmentação das atividades entre Operação, Manutenção e Engenharia - variável de pesquisa 3 (dados da tabela 5.3 das páginas 79 a 81):

Sabe-se que um dos fatores que diferenciam o trabalho da Operação do trabalho da Engenharia e da Manutenção é o regime de tempo. Enquanto a primeira ocupa-se de controlar o processo de produção vinte e quatro horas por dia, os demais são acionados pela Operação para tratar de situações constatadas por ela ou identificar problemas e oportunidades mediante análises que realizam. Esse acionamento ocorre por meio de formas sistematizadas e rotineiras, como pela emissão de solicitações de serviços de manutenção e de solicitações de estudos e projetos ou, em casos mais urgentes, pelo contato direto entre as pessoas dos diferentes segmentos.

Assim, sem necessariamente excluir a participação em projetos, com prazos mais longos, as atividades que mais ocupam os operadores, técnicos e gerentes da Operação, são as ações de curto prazo, às vezes com duração de minutos e até segundos, para manter o processo sob controle nos mais diversos aspectos (taxa de produção, qualidade, enquadramento das variáveis ambientais etc.) para atender aos programas de produção. O mesmo raciocínio se aplica à Manutenção onde, embora com tempos maiores que a Operação, uma vez que a duração das intervenções de manutenção usualmente varia de horas a semanas, existe sempre a preocupação de manter os equipamentos disponíveis para funcionar. Já a Engenharia, a par dos "trabalhos por demanda" citados no parágrafo acima, tem como atividades principais a elaboração de projetos de melhoria dos processos e instalações e, especialmente a engenharia de processo, a identificação de tendências de comportamento das variáveis dos processos de produção. No caso da Fertilizantes, por exemplo, a freqüência de acompanhamento das variáveis de processo pela engenharia varia de semanal a mensal, dependendo da variável.

Nos dois casos pesquisados, esses ciclos de curto ou curtíssimo prazo da Operação e da Manutenção e o ciclo mais longo da Engenharia se cruzam nas reuniões diárias de produção. Num primeiro momento dessas reuniões, o Coordenador de Turno ou Supervisor faz um breve relato sobre a situação dos principais aspectos do sistema de produção. Em um segundo momento, cada gerência setorial da Operação aborda as situações pertinentes à sua área. Enquanto na Fertilizantes esse segundo momento é informal, na RPBC ocorrem rápidas reuniões para cada gerência setorial de operação. 
Participam gerentes setoriais, técnicos e operadores da equipe do dia da Operação, engenheiros de processo da Engenharia e, quando há eventos significativos, supervisores e técnicos da Manutenção e engenheiros que analisam o desempenho e estudam problemas dos equipamentos, da Engenharia. Nessas reuniões são relatadas as situações dos processos de produção das diversas unidades que compõem as fábricas e combinadas as principais ações para o dia. Tratam-se, portanto, de reuniões para breve análise das ocorrências e de planejamento de curtíssimo prazo, como tratar da intervenção de manutenção em um equipamento que apresentou defeito na noite anterior ou entender o comportamento de alguma variável de processo que está com dificuldade de controle. São ocasiões, conforme dito por operadores e engenheiros entrevistados, em que a Engenharia alerta as demais áreas sobre tendências identificadas nas análises que faz das variáveis de processo (a Engenharia analisa os processos ao longo do tempo - ciclo longo), ao mesmo tempo em que toma conhecimento das variações pontuais (ciclo curto). No dizer dos entrevistados, a Engenharia procura antecipar situações que necessitarão ações de controle, tanto da Operação como da Manutenção, ou, usando os conceitos expostos, busca predizer possíveis eventos não esperados para que sejam tomadas medidas antecipadamente.

Uma outra forma de dividir o trabalho desses segmentos é com respeito à abrangência. A Engenharia vê os processos como um todo, visando maximizar o desempenho das unidades de produção. O acompanhamento do processo de produção pela Engenharia visa obter rendimentos melhores, redução de emissões, avaliação do desempenho de catalisadores, das temperaturas, das características físico-químicas de produtos etc. Já a abordagem da Operação e da Manutenção é a partir de cada equipamento ou sistema operacional. O sistema operacional, na linguagem da produção, é um conjunto de equipamentos que realiza determinada função dentro do processo. Por exemplo, o sistema de tratamento de gasolina é um conjunto de equipamentos dentro de uma unidade de processo produtora de gasolina que tem a função de remover contaminantes que não podem estar presentes no produto final ou que só podem aparecer abaixo de determinados teores, como o caso dos compostos de enxofre.

$\mathrm{Na}$ RPBC, os engenheiros de equipamentos - engenheiros que elaboram projetos mecânicos, elétricos e de outras especialidades, e que trabalham com engenharia de manutenção, foram transferidos há alguns anos da estrutura organizacional da Manutenção para a da Engenharia. Houve desta forma um afastamento desses 
engenheiros do dia-a-dia da Manutenção. Um desses engenheiros definiu assim a diferença das duas situações: os engenheiros, já nos "módulos de engenharia", passaram a tratar os problemas crônicos identificados nos equipamentos, desenvolvendo projetos para solucionar os problemas ao invés de serem absorvidos pelo dia-a-dia da Manutenção. Segundo o entrevistado, foi a "fase áurea", que se estendeu até mais ou menos o ano de 2000. Na opinião desse engenheiro, a saída dos engenheiros da Manutenção ocasionou salto de qualidade na Manutenção e nos resultados do sistema de produção. A partir daí passou a ocorrer outro problema: os engenheiros vêem-se absorvidos pelo desenvolvimento dos projetos e deixam de prestar a assistência técnica que a Manutenção necessita.

Percebe-se da fala desse engenheiro a avaliação positiva da mudança de abrangência do seu trabalho. Porém, ele destaca um problema: a absorção do profissional pelos compromissos com projetos de engenharia compete com a disponibilidade para atender demandas de prazo mais curto de assistência técnica à Manutenção. Esse problema também foi apontado pelo pessoal da Manutenção.

Em resumo, os principais fatores divisores do trabalho da Operação, da Manutenção e da Engenharia são o ciclo de tempo e a abrangência. Enquanto os dois primeiros segmentos têm foco preponderante no curto e curtíssimo prazo (agir imediatamente), a Engenharia está voltada a trabalhos, tanto estudos e projetos como controle de processos, de prazos mais longos. A Engenharia tem uma abordagem mais sistêmica dos problemas, por exemplo, desempenho global do processo ou problemas críticos em equipamentos, a Operação e a Manutenção tendem a abordar equipamentos e sistemas operacionais. Todavia, esses ciclos e essas abordagens precisam de mecanismos de conexão, dentre os quais foram citados os grupos formados para solução de problemas e como acaba acontecendo com as reuniões diárias operacionais.

5.2.4 Quanto à diferenciação da execução - variável 4 de pesquisa (dados da tabela 5.4 das páginas 81 a 82) e à especialização da execução - variável 5 de pesquisa (tabela 5.5 da página 82 )

Foram relatados casos em que a Operação recorre à Engenharia para elaborar procedimentos de manobras ou operações onde são necessários conhecimentos 
técnicos que os operadores não dominam. A execução desses procedimentos pela Operação, que detém as habilidades para parar, partir, alterar os ajustes dos equipamentos e o conhecimento prático dos sistemas operacionais, pode requerer nesses casos que a Engenharia também acompanhe as operações. Da mesma forma, para realização de algumas manobras operacionais, a Operação recorre à Manutenção, para abrir e fechar tampas de equipamentos, conectar e desconectar linhas e mangueiras para drenagens, por exemplo.

Para a implantação de projetos, muitas vezes a Engenharia recorre à Manutenção, que possui pessoas com conhecimento e experiência nas intervenções nos equipamentos. Supre, dessa forma, a carência de pessoas com esse tipo de capacidade.

Uma situação bastante ilustrativa dessa busca de conhecimentos e habilidades em outros domínios foi apresentada pela Refinaria, o caso dos projetos de automação. $\mathrm{Na}$ Fertilizantes não se verificou a mesma situação por não ter um grau de automação tão avançado quanto na Refinaria, mas pode ser feito um paralelo com outros casos de implantação de projetos. O desenvolvimento do projeto de automação é feito na Engenharia, pelos especialistas nos processos e pelos especialistas em automação. Usualmente a Operação designa um operador para participar do projeto, ficando este encarregado de informar variações que podem ocorrer nos processos, com base na experiência, que serão representadas nos modelos de automação, elaborar as telas de controle do SDCD, que são usadas nas estações de trabalho dos operadores, e treinar os demais operadores na operação do sistema automatizado.

$\mathrm{Na}$ fase de implantação, a Engenharia (pessoal de automação) faz a configuração do SDCD, que inclui a elaboração da lógica de controle. A automação elabora essa lógica em planilhas e o pessoal da Manutenção, especialistas em instrumentação, carregam a lógica nas máquinas.

Ainda na implantação, a equipe de automação participa do treinamento dos operadores nos sistemas novos, em conjunto com a Operação. No campo, é realizado o loop-test, junto com o pessoal da Manutenção - Instrumentação, que consiste na verificação do envio e chegada de sinais dos instrumentos de campo para o SDCD e vice-versa. 


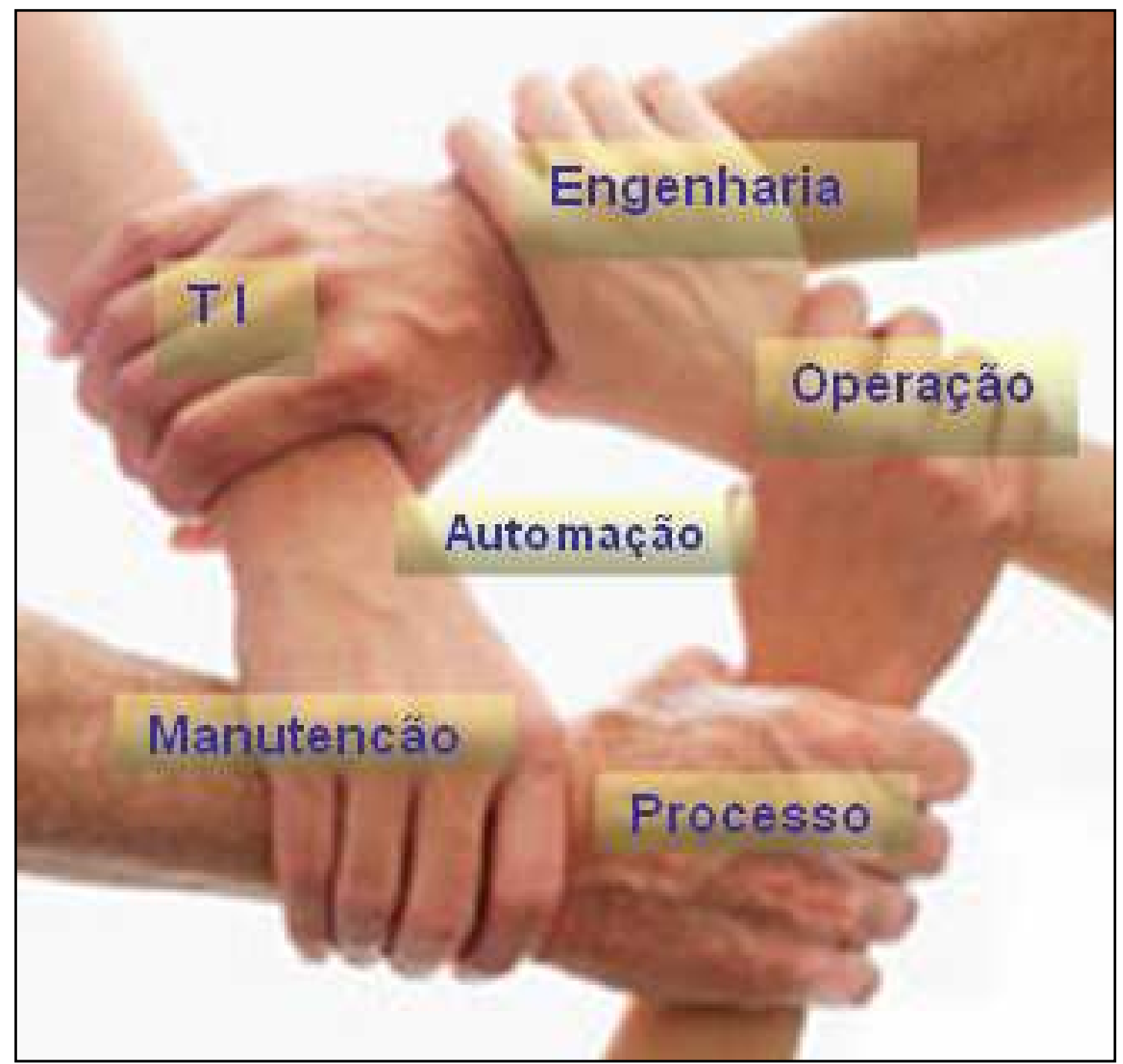

Fig. 5.1: Representação ilustrativa da importância da integração entre funções (domínios organizacionais) para o sucesso do controle de processos, conforme visão da engenharia de automação da RPBC. Fonte: RPBC.

Recentemente um estudo de comparação de desempenho de controle de processo (automatizado) realizado pela empresa de consultoria Solomon Brothers, com a participação de 36 refinarias de petróleo de diversos países, identificou a RPBC como tendo um dos sistemas de controle de processos mais avançados. Ao expor o resultado desse estudo para um público constituído de pessoas que trabalham nos diversos domínios organizacionais e de diferentes funções profissionais, o coordenador da engenharia de automação destacou a integração entre as diferentes áreas como um dos fatores primordiais para esse sucesso. Nessa exposição, foi mostrada a ilustração apresentada na Fig. 5.1. 
Portanto, a variável diferenciação da execução fica entendida, em uma abordagem de interfaces com outros domínios, como a necessidade de uma área recorrer a pessoas de outro segmento quando precisa de conhecimentos e habilidades que não domina para dar prosseguimento a um trabalho. Essa conclusão torna essa variável coincidente com a quinta variável de pesquisa, que é a especialização da execução. E ainda junto com os exemplos apresentados, reforça, mais uma vez, que a boa interface é determinante da eficácia do sistema de produção. Há que se ressaltar ainda, que em boa parte dos exemplos apresentados essas interfaces não acontecem via mecanismos tradicionais de coordenação de atividades divididas entre os domínios organizacionais. Quando se trata de juntar conhecimentos, as fronteiras entre os domínios deixam de ser fixas e passam a ser móveis e interpenetrantes.

\subsubsection{Quanto à separação das funções de execução e controle e especialização do controle - variável de pesquisa 6 (dados da tabela 5.6 das páginas 83 e 84)}

A idéia inicial da pesquisa era trabalhar com duas variáveis diferentes, uma separação das funções de execução e controle e outra especialização do controle, que são dois parâmetros de projeto organizacional da teoria de projeto sociotécnica moderna (SITTER et al., 1997). Entretanto, constatou-se, já nas primeiras entrevistas realizadas, que a separação entre execução e controle em domínios organizacionais diferentes ocorre quando houver necessidade de capacitações diferentes daquelas de quem executa para realizar as atividades de controle. A partir dessa constatação, foi feita a opção de tratar as duas variáveis de pesquisa conjuntamente.

Considera-se que o trabalho de operar um processo contínuo é, principalmente, o trabalho de manter sob controle as variáveis desse processo de produção em diversas condições de operação, ou seja, lidar com as variabilidades dos processos. São exemplos dessas variabilidades: processamento de matérias-primas com características de qualidade diferentes da usual, mudanças de especificações de produtos para atender determinados mercados, manter a taxa de produção com equipamentos apresentando condições de funcionamento diferentes da desejada etc (AULICINO, 1998; SALERNO, 1999). Assim, operar o sistema de produção tem o 
significado de dirigir os processos de produção para obter metas desejadas, ou seja, obter dirigibilidade dos processos.

Nos casos estudados as decisões sobre possíveis mudanças nos parâmetros dos processos de produção são tomadas pela Operação, sendo que as decisões de maior responsabilidade são tomadas pelos níveis gerenciais. Entretanto, nos assuntos e problemas de maior complexidade técnica é usual a Operação recorrer à Engenharia e à Manutenção para emitir pareceres ou formar grupos de trabalho multifuncionais a fim de colher subsídios para as ações de controle, que incluem mudanças de parâmetros e correções de problemas. Da mesma forma, os gerentes se apóiam nos pareceres técnicos, muitas vezes emitidos por grupos de trabalho especialmente formados para analisar tecnicamente os problemas, para tomarem decisões.

Porém, foram encontradas algumas situações em que a definição de ações de controle deixa de ser feita pela Operação e passa para outras funções. Por exemplo, no caso de problemas críticos de equipamentos, o parecer da Manutenção ou, nos casos mais complexos, da Engenharia sobre manter ou não equipamentos defeituosos funcionando tem força de decisão. Mais uma vez deixam de existir fronteiras fixas para a atuação de cada domínio organizacional no sistema de produção. Outro exemplo significativo é o de planejamento e programação de produção, que não são realizados pela Operação. Os planos de produção são definidos corporativamente, levando em conta as necessidades dos mercados e as possibilidades de atendimento pelos conjuntos de fábricas das empresas e detalhados e controlados por equipes locais. No caso da Fertilizantes, a programação local é feita por uma equipe do órgão corporativo de PCP. Na Refinaria, o detalhamento do plano de produção, a programação e controle são realizados por uma equipe da engenharia de processo, que participa do planejamento da produção realizado no âmbito corporativo. Assim, as metas de produção são definidas externamente à Operação, embora ela seja consultada para a elaboração dos planos e programas de produção.

Ao ser questionado sobre o porquê da alocação da atividade de Planejamento, Programação e Controle da Produção na área de Engenharia e não na Operação, o gerente da Engenharia da Refinaria a quem está subordinada a equipe responsável pela atividade relatou que as duas situações já ocorreram. Entretanto, o 
posicionamento do PCP na Engenharia mostrou-se a melhor opção tendo em vista o maior suporte técnico oferecido dentro da Engenharia, com maior competência para tratar questões de médio e longo prazo, enquanto a equipe de Operação tem visão mais executiva. Ressaltou ainda que o controle de produção tem uma forte componente de análise, o que o aproxima da atividade de análise de processos, realizada pelos engenheiros de processo. Dessa forma, o Planejamento, Programação e Controle da Produção, junto com a Engenharia de Processo, funcionam como uma espécie de controladoria do sistema de produção, concluiu.

Outra situação que está ligada à controlabilidade do sistema de produção, relatada pelos entrevistados dos casos estudados, mas com maior ênfase na Fertilizantes, diz respeito à definição de prioridades dos projetos e estudos solicitados pela Operação e pela Manutenção à Engenharia. Esses projetos incluem modificações nas instalações para corrigir problemas, melhorias para facilitar a operação, eliminação de condições inseguras etc., além de modificações para permitir obter novas especificações de produtos, redução de custos, melhores rendimentos, dentre outros objetivos. Foi relatado que nem sempre a Operação, que assume condição de cliente dos projetos, define as prioridades de modo considerado adequado pela Engenharia, seja por definir prioridades com as quais a Engenharia não concorda, seja por demandar quantidades de projetos tidos como igualmente e extremamente prioritários que vão além da capacidade de realização física, limitada pelos recursos da Engenharia. Também foram registradas manifestações de entrevistados da Manutenção, e aí com maior ênfase dos entrevistados da RPBC, com a assistência técnica prestada pela Engenharia na resolução de problemas, devido ela estar voltada principalmente à realização da carteira de projetos definida para o período.

A esse respeito, é interessante analisar o que disse um gerente de produção. $\mathrm{Na}$ opinião do entrevistado (não é necessariamente a visão dos outros gerentes), o objetivo da produção é maximizar o lucro - o que nem sempre significa reduzir custos das atividades realizadas, enquanto a Manutenção fixa-se em redução de custos e a Engenharia em cumprir sua agenda de projetos. Ou, ainda, o depoimento de um engenheiro de processo: há conflitos de objetivos, principalmente entre Operação, Engenharia de processo e órgãos de Manutenção que cuidam de instrumentação e do controle de integridade física dos equipamentos. Um quer preservar os equipamentos ao longo do tempo, pensando em maximizar a vida útil, 
enquanto outro, pensa que forçar os equipamentos (operar próximo às condições limites), mesmo com sacrifício da vida útil, compensa, ou seja, dá retorno financeiro.

Quanto ao "forçar o equipamento" e outras mudanças nos parâmetros dos processos que venham ser recomendadas, foram identificadas também diferenças de postura frente às mudanças dentro de um mesmo segmento. O exemplo é a mudança de temperatura de operação para maior de um forno, o que segundo estudos da Engenharia junto com empresa especializada no assunto traria ganhos econômicos, com a qual concordava o gerente de Operação da área. Um dos questionamentos dos operadores era se o forno não se danificaria, oferecendo riscos inclusive de segurança, ao trabalhar com temperaturas mais altas do que as praticadas até então. O gerente da área, oriundo da engenharia de processo, cônscio de que a mudança não levava a extrapolar limites seguros, convenceu os operadores sobre a segurança da nova condição operacional e a mudança foi implantada com sucesso.

De fato, a discussão sobre diferenças de objetivos entre órgãos de uma estrutura departamentalizada já apareceu diversas vezes na literatura. Mas também isso ocorre quando se adota uma organização por processos, com as pessoas privilegiando ações em busca do resultado dos processos dos quais participam mais diretamente e pelos quais são avaliados em detrimento dos resultados de outros processos ou sem a visão da contribuição para os resultados globais, ligados às principais estratégias da organização (SALERNO, 1999).

Algumas soluções para compatibilizar essas diferenças são utilizadas nas empresas pesquisadas. A participação da Operação e da Manutenção no desenvolvimento dos projetos ocorre, embora com deficiências. As reuniões operacionais diárias servem para alinhar os objetivos de curto prazo. A constituição das equipes de continuidade operacional na Refinaria serviu para melhorar bastante a programação dos serviços de manutenção, mediante análise das prioridades pelo pessoal de Operação e o planejamento dos serviços feito conjuntamente pelos técnicos da Operação, da Manutenção e, quando necessário, da Segurança Industrial, considerando integradamente os diversos aspectos das intervenções que são realizadas.

Outro problema existente na pilotagem do sistema de produção é o da percepção da necessidade de se envolver outras funções para resolução de uma situação. Nem sempre a Operação se antecipa aos problemas e aciona a Engenharia e a Manutenção para analisar uma situação que foge à normalidade antes das 
conseqüências indesejadas se instalarem. Uma possível explicação para isso está no depoimento de um engenheiro: a Operação trabalha com base em experiência, ou seja, analisa os fatos pela comparação com os históricos dos processos e a experiência pessoal dos operadores e técnicos, o que se constitui em limitante à sua percepção de situações ainda não vivenciadas.

De qualquer forma, há vários exemplos de atuação dos operadores acionando tanto a Manutenção como a Engenharia para resolver problemas e melhorar sistemas existentes. No caso de redução dos tempos de parada e partida das unidades de coque da Refinaria, a iniciativa partiu da Operação, que solicitou e teve apoio técnico da Engenharia na criação de facilidades e estudo de restrições técnicas para mudar os procedimentos existentes, possibilitando eliminar ou alterar atividades mais longas e críticas. Um dos engenheiros relatou que é comum os operadores telefonarem diretamente aos engenheiros para tirar dúvidas sobre o sistema automatizado implantado. Um exemplo de questionamento é a existência de alarmes de monitoramento de vibração de máquinas atuando com muita freqüência. Nesses casos, a engenharia de equipamentos faz uma análise para verificar se o valor especificado para acionar o alarme está demasiadamente baixo, ou se há realmente um problema com aquela máquina. Na visão desse mesmo engenheiro, o limite para os operadores, na questão da controlabilidade, é o conhecimento técnico. O operador identifica problemas e oportunidades de melhoria, mas precisa da engenharia para analisá-los.

Outra abordagem das duas situações foi dado por um gerente de manutenção: a Operação tem muitas informações nas telas do SDCD e com isso consegue fazer alguma predição de falhas. Por exemplo, pelo aumento de pressão os operadores percebem que certo equipamento está obstruído; o aumento de temperatura dos tubos de fornos indica a formação interna de películas que restringem a vazão e prejudicam a troca de calor. Essa atuação de predição acontece quando a Operação percebe que o relato desses sinais é benéfico para todos. Mas há outras situações ou ocorrências que acabam sendo relegadas pela Operação. Por exemplo, alarmes de falhas de sistemas, como falhas de cartões de programação do SDCD e de cabos condutores de sinais no campo não são relatados pelos operadores à Manutenção - Instrumentação se não considerarem a falha importante. Porém, essas falhas podem estar indicando a ocorrência de problemas mais sérios no futuro. 
A Manutenção, por sua vez, pode alertar a Operação sobre algumas variações. Um supervisor da Manutenção relatou que quando foi trocada temporariamente a matériaprima da unidade de geração de hidrogênio de gás natural para nafta, os operadores não possuíam "sensibilidade" das variáveis do processo com essa matéria-prima, que apresentavam valores diferentes de quando se utiliza gás natural. A Instrumentação deu apoio à Operação confirmando a exatidão das medidas informadas pelos instrumentos. Foi dito também que quando a Manutenção percebe a ocorrência de danos ou desgastes anormais em equipamentos, como em válvulas de controle, alerta a Operação sobre possíveis anormalidades nos processos produtivos. Ou seja, rompem-se as fronteiras das atividades de cada segmento com a participação do pessoal da instrumentação no trabalho de operar o sistema de produção. As interfaces ocorrem através da junção dos conhecimentos dos processos de transformação e dos instrumentos de medição, atuando sobre eles se necessário, o que caracteriza uma interpenetração das fronteiras organizacionais da Operação e da Manutenção.

Com relação à Engenharia, a Manutenção Ihe reporta premissas erradas de projeto, identificadas pela observação do funcionamento dos equipamentos, ou mesmo ao acompanhar a montagem deles.

Em síntese, pode se afirmar que ocorre separação entre execução e controle quando a área responsável pela execução, geralmente a Operação, mas também a Manutenção, não possui conhecimentos técnicos para definir ações de controle frente às situações que se apresentam. Nesses casos, a função com mais domínio técnico do assunto assume o papel de definir as ações de controle necessárias. Logo, um parâmetro importante para a organização do trabalho é quando e como um dos domínios passa a responsabilidade pelas decisões de ações de controle aos demais segmentos ou a divide com eles. Mais do que caracterizar uma separação entre execução e controle, caracteriza-se a fluidez das fronteiras organizacionais. Os dados aqui mostrados apontam que isso ocorre em razão da complexidade técnica das situações que se apresentam e das competências técnicas existentes em cada domínio.

Um segundo ponto de relevância é a percepção das situações que requerem intervenções corretivas, quando a falha já ocorreu, ou de caráter preditivo, pela detecção de situação que levará a uma falha no futuro. Em razão dos conhecimentos, habilidades e mesmo das atividades diferentes, um segmento pode ser capaz de identificar situações anormais ainda não percebidas por outros. Ao alertar os demais, 
acaba interferindo de forma positiva em atividades de controle que estão fora das suas fronteiras organizacionais.

Passa a ser importante para o projeto organizacional identificar as competências necessárias para monitoramento de variáveis do processo de produção e onde estão localizadas essas competências. Aliás, as competências são um dos fatores de integração da estrutura organizacional quando definidas em função das necessidades da empresa ou do sistema de produção, neste caso, e estabelecidas na organização (LIMA e LEZANA, 2005).

Em seguida, prever a coordenação, com ênfase na comunicação, entre os diferentes segmentos e domínios organizacionais, desde a identificação de anormalidades até a definição das ações pertinentes de controle dos processos. Essa coordenação/comunicação deve ser tal que possibilite a intercompreensão entre as diferentes áreas dos problemas, suas causas e soluções a adotar (ZARIFIAN e AUBÉ, 2003, ZARIFIAN, 1996; SALERNO, 1999).

\subsubsection{Quanto à diferenciação do controle - variável de pesquisa 7 (dados da tabela 5.7 da página 85).}

Foi consenso nas empresas pesquisadas que a Engenharia trabalha com foco no médio e longo prazo e tem uma abordagem mais tática do sistema de produção, enquanto a Operação tem uma atuação mais voltada ao curto prazo e abordagem mais pontual sobre o comportamento das variáveis do sistema de produção.

Foi observado ainda que as principais metas do sistema de produção são elaboradas pelo pessoal de Engenharia, com participação do pessoal de Operação e Manutenção, invertendo a lógica até aqui apresentada para o gerenciamento da Produção, em que a Operação era o ator imediato. Também os planos de caráter mais estratégico, que envolvem questões como mudança tecnológica, novos produtos, aumento de capacidade de fabricação, são desenvolvidos pela Engenharia. Ou seja, a Engenharia assume a liderança quando se tratam de questões de médio e longo prazo, que geralmente são as de cunho tático e estratégico. 


\subsection{CONCLUSÕES: CARACTERÍSTICAS RELATIVAS ÀS INTERFACES A SEREM CONSIDERADAS NO PROJETO ORGANIZACIONAL DO TRABALHO}

Foram efetuadas acima análises dos dados obtidos por meio dos casos estudados. Partindo dessas análises, é possível tirar conclusões sobre características relativas às interfaces entre Operação, Engenharia e Manutenção em sistemas de produção por processos contínuos, que devem ser consideradas no projeto de organização do trabalho em sistemas desse tipo.

Foi verificada a existência de unidades organizacionais que se diferenciam não apenas pela divisão do trabalho estabelecida, mas pela detenção de conhecimentos e habilidades diferentes e necessários ao funcionamento do sistema de produção, como neste estudo os domínios organizacionais da Operação, da Engenharia e da Manutenção.

Ao analisarem-se as possibilidades de segmentação das atividades, e quando elas se realizam complementarmente em mais de um domínio, percebeu-se que o ciclo de tempo e abrangência constituem-se em fatores divisores do trabalho da Operação, da Manutenção e da Engenharia. Entende-se por abrangência, neste caso, a diferença das abordagens que prevalecem na atuação de cada domínio: se uma abordagem mais global e sistêmica, como apareceu na Engenharia nos casos estudados, ou abordagem por equipamentos e por partes do processo de fabricação, como pareceu ser mais adotada pela Operação e pela Manutenção (nos casos estudados, as partes dos processos são identificadas com as unidades operacionais ou de processo). Notou-se ainda a prevalência de ciclos mais longos de trabalho na Engenharia em relação aos demais domínios.

É de extrema importância que esses diferentes ciclos de tempo e abordagens se interliguem através de práticas adequadas, como as reuniões diárias operacionais e os grupos formados para tratamento de eventos, que puderam ser observadas durante a pesquisa.

Práticas como essas se constituem em mecanismos de coordenação da atuação dos segmentos pertencentes a domínios diferentes. Os mecanismos de coordenação têm grande importância por não se tratar simplesmente de interfaces resultantes da 
segmentação dos processos de produção, como na teoria sociotécnica moderna estudada, em que um segmento conclui uma etapa do processo e outro segmento dá continuidade a esse processo. Na grande parte dos casos, trata-se da intervenção conjunta de segmentos de domínios diferentes. No caso das situações não rotineiras, os mecanismos de coordenação entre esses domínios têm que garantir agilidade para que o prazo de resposta seja o mais adequado. Por exemplo, os casos citados de problemas que podem estar causando redução da taxa de produção ou desvio de qualidade de produto. É necessário identificar as causas, definir a solução e executar a correção no menor prazo possível.

Da análise das variáveis de pesquisa diferenciação e especialização da execução, pode-se concluir que é necessário identificar e tratar as situações em que um determinado segmento organizacional não possui todos os conhecimentos e habilidades necessários à execução de certas atividades ou que a execução por outros seja mais vantajosa, localizar quem os detém na organização e estabelecer a forma adequada para que o trabalho seja realizado com a participação dos demais domínios.

Outro ponto a ser tratado no projeto organizacional, obtido da análise da sexta variável de pesquisa - separação das funções de execução e controle e especialização do controle, é a responsabilidade pelas decisões de ações de controle. Embora tenha sido visto que na maioria das vezes a liderança da tomada de decisões caiba à Operação, essa liderança pode ser exercida pelo domínio que possua maior conhecimento técnico para abordar determinado problema do sistema de produção. Nesse caso, o parecer técnico sobre o que fazer diante do problema passa a ser o balizador das decisões para dirigir o sistema.

Ainda com relação ao domínio técnico para exercer o controle, levando em conta inclusive características já abordadas como abrangência de atuação, um domínio pode ser capaz de identificar situações anormais que outros domínios não tenham a mesma facilidade de perceber. Assim, é importante alocar as atividades de controle dos processos de produção considerando que um mesmo componente do processo seja pilotado por mais de um domínio, conforme abordagens diferentes e complementares, através de um fluxo de informações compartilhadas que possibilitem decidir sobre as ações para condução do processo. 
Ressalta do exposto acima que, se o projeto organizacional sociotécnico moderno busca reduzir as fronteiras organizacionais como forma de reduzir as variações no sistema de produção e aumentar a dirigibilidade, por outro lado há fronteiras que não se pode eliminar e que não são fixas. Elas têm como características mobilidade, conforme os eventos, e interpenetração, isto é, o compartilhamento das ações por diferentes domínios organizacionais.

Por fim, a variável de pesquisa diferenciação do controle evidenciou que as considerações anteriores acerca de conhecimentos e habilidades, ciclo de tempo e abrangência da atuação dos domínios podem influenciar a atuação de cada um quando se pensa em diferentes níveis de controle: estratégico, tático e operacional.

Em síntese, os seguintes elementos relativos às interfaces devem ser considerados nos projetos de organização do trabalho:

- Identificação de conhecimentos e habilidades que caracterizem elementos e subsistemas organizacionais ou funcionais diferentes;

- Alocação de tarefas ou atividades de uma mesma etapa de processo a domínios e segmentos diferentes, conforme as competências necessárias a cada tarefa e atividade;

- Os mecanismos de coordenação devem ser instrumentos para a interligação de ciclos diferentes de tempo e de abrangências de atuação em que trabalham os domínio e seus segmentos;

- Estabelecimento de princípios para exercício da liderança na definição de ações de controle do sistema de produção, considerando o domínio técnico sobre as questões tratadas como atributo para liderar;

- Existência de situações de compartilhamento do controle, entendido como a pilotagem dos processos tanto em situações de produção normal como no tratamento dos eventos, levando em conta a gama de atividades (competências necessárias, abrangência e tempo), conhecimentos e habilidades de cada segmento, sustentadas por um fluxo de informações que leve à ação de correção mais adequada; 
- Criação de mecanismos de coordenação das ações dos domínios e segmentos que venham a intervir conjuntamente nos processos do sistema de produção, nas fronteiras organizacionais móveis e interpenetrantes. 


\section{PROPOSIÇÃo dE CONCEITOS E MÉtOdo DE PROJETO ORGANIZACIONAL PARA PROCESSOS CONTÍNUOS}

Neste capítulo, tendo por base as análises dos dados resultantes da pesquisa realizadas, são feitas proposições conceituais e metodológicas para atacar as lacunas existentes na teoria de projeto de organização do trabalho, tendo em vista sua aplicação aos sistemas de produção contínuos.

\subsection{PROPOSIÇÕES CONCEITUAIS E METODOLÓGICAS}

As estratégias de projeto organizacional apresentadas pelos autores da linha sociotécnica moderna foram descritas no capítulo 2. Os conceitos, parâmetros e regras de projeto organizacional apresentados têm foco na organização do trabalho na Operação. A teoria adotada aplica a paralelização e a segmentação ao fluxo do processo de fabricação, como método para definição das unidades organizacionais, estabelecendo as fronteiras entre os segmentos, ainda que com o propósito de reduzilas. No geral, aplica as definições acerca dos parâmetros estruturais para fazer a segmentação e a estruturação interna dos segmentos. Define espaços de comunicação, sistemas de informação etc.

Porém, no caso de processos contínuos, muitas das fronteiras, e fronteiras entre domínios diferentes como Engenharia, Operação e Manutenção, não podem ser eliminadas. Tão pouco se tratam de fronteiras rígidas e pré-definidas, que ditam simplesmente a divisão do trabalho entre unidades organizacionais. As fronteiras organizacionais se interpenetram, e mudam conforme os eventos da produção, fazendo inclusive que ocorra um compartilhamento de responsabilidades em certas ocasiões. 
Os enfoques teóricos tratam das fronteiras como rígidas, ou seja, como a relação entre unidades organizacionais dadas que interagem, mas cada uma no âmbito do seu domínio, com atribuições e responsabilidades pré-definidas. Não se trata o caso mais fluido, quando dois ou mais subsistemas, domínios ou unidades organizacionais distintos trabalham juntos, no interior de um dado domínio, para atuação naquele domínio, como quando a Engenharia atua na Operação, que está fora do seu domínio.

Isso coloca uma questão de dinâmica da estrutura organizacional inédita: projetar a ação conjunta, não mais projetar apenas a separação.

Então, a teoria para projeto de organização do trabalho de base sociotécnica moderna é revista a seguir. Será proposta uma abordagem que integra a organização do trabalho nos domínios pela inclusão na metodologia de projeto do tratamento das interfaces existentes entre eles, no caso, Operação, Engenharia e Manutenção.

Em adição aos conceitos de projeto - projeto integral, dirigibilidade, definição conjunta das estruturas de produção e de controle e parâmetros estruturais - será proposto um princípio, relativo aos mecanismos de coordenação, que têm grande impacto na dinâmica organizacional. O conceito de controlabilidade é enunciado com o uso de outro conceito, o de evento, e a utilização de termo dirigibilidade. Procurou-se, dessa forma, fazer a ligação do conceito de dirigibilidade com a comunicação organizacional, nas suas dimensões cognitiva, normativa e expressiva, que têm os eventos como momento relevante.

Os parâmetros estruturais ganharam explicações e considerações diferentes daquelas criadas por seus autores para incorporar à teoria os elementos para projeto organizacional identificados na presente pesquisa. As considerações sobre esses parâmetros incluem as competências necessárias, o compartilhamento do controle, a liderança técnica em tomadas de decisão, as possíveis diferenças de abrangência e ciclo na ação de cada segmento ou domínio da organização. Os exemplos que ilustram possíveis variações desses parâmetros incorporam os dados colhidos nos sistemas de produção contínua pesquisados. 
Por fim, a proposta redefine as regras para projeto de organização do trabalho, para considerar novas etapas e seqüência para elaboração do projeto organizacional, em razão dos elementos incorporados ao referencial teórico.

Essas proposições são detalhadas a seguir.

\subsection{REVISÃO DOS CONCEITOS DE PROJETO}

\subsubsection{Parâmetros Estruturais}

Os conceitos da teoria sociotécnica moderna se traduzem para o projeto de estrutura organizacional através das definições relativas aos parâmetros estruturais, que foram expostas no Capítulo 2. Diversas considerações precisam ser feitas acerca dos conceitos desses parâmetros, tendo em vista os sistemas de produção contínuos.

Com respeito aos parâmetros concernentes à estrutura de execução, os autores sociotécnicos pesquisados focam em seus trabalhos as atividades diretas. Porém, em se tratando de uma abordagem de projeto que busca a integração de diferentes funções, o escopo do projeto organizacional deve incluir as atividades de execução dessas outras funções, naqueles processos que interferem no sistema de produção. Um exemplo em que as atividades são do processo de projeto, relativo ao parâmetro estrutural especialização da execução, seria quando ao realizar uma melhoria no sistema de controle operacional de uma das unidades de produção, a equipe de automação da Engenharia projeta uma malha de controle, a área especializada de instrumentação da Manutenção carrega os parâmetros de controle nos equipamentos digitais de controle e a equipe de operação da unidade aciona os equipamentos para, junto com as equipes da Engenharia e Manutenção testarem o sistema. Nesse caso, a execução do teste da malha de controle tem atividades 
alocadas em segmentos de domínios organizacionais diferentes daquele executante do projeto, que é a equipe de automação de processos da Engenharia.

Assim, com relação aos parâmetros estruturais concernentes à execução podem ser propostas as seguintes redações, onde as alterações efetuadas nos enunciados apresentados no Capítulo 2 são destacadas em itálico:

Primeiro Parâmetro: Concentração Funcional - Diz respeito a como as funções de execução são agrupadas ou ligadas com relação às ordens de produção ou às transformações entradas - saídas. Há duas possibilidades extremas: atribuição das ordens de produção a todos os subsistemas (como num arranjo funcional de metalúrgicas, quando a ordem vai para a tornearia, para a seção de fresa, de retífica, para a montagem etc.) ou atribuição de cada ordem a apenas um subsistema específico (enunciado não alterado, trata especificamente do fluxo de fabricação e não é impactado pelas discussões realizadas).

Segundo Parâmetro: Diferenciação da Execução - Refere-se à divisão do trabalho, tanto nas atividades diretas como nas atividades indiretas dos domínios organizacionais que atuam no sistema de produção, nas funções preparar, apoiar e produzir em subsistemas especializados.

Terceiro Parâmetro: Especialização da Execução - Refere-se ao desmembramento de uma subfunção de execução, de atividades diretas e indiretas, em atividades alocadas em subsistemas separados, inclusive unidades de outros domínios organizacionais que detenham competências necessárias à execução.

Relativamente aos parâmetros estruturais que definem a estrutura de controle, foi mostrado que parte significativa do controle é feita por órgãos externos à Operação. Nos casos estudados foi encontrado o exemplo do planejamento e controle da produção (PCP). Na Refinaria ele é exercido pela engenharia de processos, uma vez que o planejamento e o controle da produção estão intimamente ligados à otimização dos processos, que é uma das atribuições da Engenharia. Na Fertilizantes há um órgão corporativo que cuida do PCP de várias unidades industriais da empresa. Nessa situação há um controle sobre os processos de produção desempenhado pelos PCP, que são unidades organizacionais externas ao domínio da Operação. 
Cabe ainda ressaltar que, tendo em vista a telemática, engenheiros de processo, especialistas de manutenção e outros podem acompanhar à distância o comportamento das variáveis dos processos de fabricação e dos equipamentos. As informações colhidas nas entrevistas mostram que esses profissionais alertam a Operação e solicitam intervenções operacionais ao constatarem tendências das variáveis monitoradas que podem ocasionar falhas. Por exemplo, o pessoal de manutenção preditiva pode detectar alguma máquina operando fora das faixas de vazão ou pressão adequadas para a confiabilidade dos equipamentos e solicitar ajustes ao pessoal de operação para evitar danos a esses equipamentos e prevenir falhas nos processos (são conhecidos eventos indesejados de quebra de componentes de bombas que apresentaram níveis altos de vibração em razão de trabalharem, mesmo temporariamente, fora da faixa segura de vazão). Nesses casos, pode-se dizer que ocorre um compartilhamento do controle sobre variáveis do processo de produção. Estas considerações são pertinentes aos parâmetros estruturais separação das funções de execução e controle e especialização do controle.

Para o parâmetro estrutural diferenciação do controle (nos níveis estratégico, tático e operacional), cabe discutir a formulação e controle de metas. Tendo em vista os processos de fabricação tratarem-se, geralmente, de processos de transformação de propriedades físicas e químicas em larga escala, a formulação de metas de desempenho relacionadas ao sistema de produção pode depender de simulações dos processos, analisando-se possíveis alternativas para os seus parâmetros, estudos de capacidade de atendimento a requisitos de qualidade, ou seja, de propriedades físicas e químicas dos produtos, estudos de capacidades dos equipamentos, análise de impactos ambientais, dentre outros fatores. Ou seja, demanda conhecimentos e habilidades dominadas pela Engenharia. Essa situação pode fazer com que a formulação e controle dessas metas fiquem a cargo da Engenharia, no nível tático, ficando a Operação com o controle operacional. Essa hipótese é reforçada com a constatação na pesquisa efetuada de que a atuação da Engenharia tem abrangência maior (sistêmica, o que facilita a visão estrutural) do que a atuação da Operação (que percebe mais os equipamentos e subsistemas, tendendo, pois a um enfoque mais operacional). 
Pode caber aqui, também uma divisão do controle segundo uma lógica temporal. Um exemplo foi apresentado por um operador entrevistado, que destacou a capacidade dos engenheiros de anteciparem situações, enquanto os operadores lidam mais com os problemas que se apresentam. Essa comparação permite associar a atuação da engenharia ao médio prazo, enquanto a atuação da Operação tende a prazos mais curtos. Uma hipótese para essa diferença seria o fato de os engenheiros, em princípio, conhecerem melhor o modelo teórico do processo e se dedicarem a estudos e análises de maior abrangência, enquanto os operadores têm sua atenção voltada ao dia-a-dia da produção.

Quanto à divisão das funções de controle, importa analisar situações em que o ciclo de controle (detecção, percepção, avaliação e definição de ações) seja dividido entre domínios organizacionais diferentes. As escolhas acerca deste parâmetro são decorrentes da complexidade tecnológica e das competências requeridas. Assim, se o pessoal de laboratório, que analisa as propriedades das matérias-primas e dos produtos, detecta algum valor fora do especificado, cabe a outros setores a identificação das causas e tomada de ações. É relevante, em termos de controle, destacar que esses ensaios não são apenas dos produtos finais, mas incluem produtos intermediários e resíduos, e os resultados servem para que os operadores efetuem correções e ajustes nos processos, visando manter o enquadramento dos produtos nas suas especificações e também os resíduos - efluentes líquidos e emissões gasosas. Outro exemplo é o de problemas em equipamentos: os operadores com freqüência percebem ruídos anormais, vibração e temperaturas fora do usual em máquinas e acionam a Manutenção para que ela analise se realmente há algum problema e, em caso positivo, indique as medidas a serem tomadas. Ou, se a Operação identifica um problema no processo de produção que não se sente capaz de avaliar, recorre à Engenharia para realizar a avaliação, muitas vezes em conjunto com o pessoal de Operação e de Manutenção. Ou ao contrário, quando a Engenharia ou a Manutenção identificam falhas potenciais, indicam à Operação para que se tomem as ações adequadas a evitar essas possíveis falhas.

Em resumo, os enunciados dos parâmetros estruturais relacionados ao controle, podem ser revisados para ficarem na seguinte forma, onde as palavras grifadas em itálico indicam diferenças em relação ao enunciado original: 
Quarto Parâmetro: Separação das funções de execução e controle - Definir se o controle dos processos é feito pelos seus executantes ou por elementos diferentes ou ainda, subsistemas diferentes. Definir a conveniência e necessidade de compartilhar o controle com outros domínios organizacionais que atuam no sistema de produção.

Quinto Parâmetro: Especialização do controle - Alocação do controle de aspectos funcionais a aspectos do sistema separados, como qualidade, manutenção, logística, pessoal etc. e a outras funções do sistema que possuam competências necessárias às atividades de controle.

Sexto Parâmetro: Diferenciação do controle - Desmembramento dos domínios de controle em níveis separados - estratégico, tático e operacional, alocados a partes diferentes da estrutura organizacional (este enunciado não foi alterado).

Sétimo Parâmetro: Divisão das funções de controle - Alocação das atividades de detecção e percepção, avaliação e definição de ações a indivíduos, elementos do sistema ou subsistemas diferentes. Identificar as situações em que dado aspecto ou aspectos correlatos - como o monitoramento do desempenho de equipamentos são monitorados por mais de um domínio ou função e compatibilizar os ciclos de controle.

\subsubsection{Mecanismos de Coordenação: um princípio que se junta aos conceitos para projeto organizacional}

Nas discussões anteriores fica destacada a necessidade de mecanismos de coordenação, através dos quais vão ocorrer as transações nas interfaces dos segmentos, notadamente os de domínios diferentes, tanto no que diz respeito à execução como ao controle. Os mecanismos de coordenação são fundamentais para a dinâmica da organização, pois, junto com a estrutura desenhada, vão proporcionar a dirigibilidade desejada. Por isso, também são parte do projeto de organização do trabalho. 
Esses mecanismos permitem exercer a coordenação sob o enfoque tradicional da articulação das tarefas em que for dividido o trabalho, com ação sobre variáveis do tipo tempo e seqüência das ações. Conforme apresentado no capítulo 2, cinco mecanismos básicos de coordenação podem explicar os modos fundamentais pelos quais as organizações coordenam seu trabalho (MINTZBERG, 1993):

Ajuste mútuo: a coordenação do trabalho acontece simplesmente pela comunicação direta. Acontece nas organizações mais simples e nas mais complexas.

Supervisão direta: uma pessoa assume a responsabilidade pelo trabalho de outros, dando instruções e monitorando suas ações.

Padronização dos processos de trabalho: quando o conteúdo do trabalho é especificado ou programado.

Padronização dos resultados do trabalho: quando, por exemplo, as dimensões ou o desempenho do produto são especificados.

Padronização de conhecimentos e habilidades: quando há um treinamento especificado para desempenhar o trabalho. Pode ser formação escolar ou acadêmica para aquele trabalho.

Alguns mecanismos de coordenação foram observados nos casos estudados, dentre eles o estabelecimento de procedimentos de trabalho, um dos mecanismos apontados por Mintzberg para situações de rotina. Estes devem considerar as necessidades de todas as fases e os pontos de passagem de trabalho entre os segmentos (por exemplo, os procedimentos de preparação devem atender as necessidades da fase de produção e prever as entregas e recebimentos de serviços, materiais, matérias-primas, insumos etc). Para situações não rotineiras (eventos), elaboração de planejamentos integrados que considerem as necessidades e participações de todos os segmentos envolvidos na execução das tarefas, esquemas de reuniões de avaliação do andamento e de replanejamento dos trabalhos.

Entretanto, os casos estudados evidenciaram que o desempenho do sistema de produção depende não só da atuação de cada um dos domínios, mas de como acontecem interações entre eles e da integração das suas ações nas fronteiras interpenetrantes. Isso acontece porque a coordenação do trabalho não se restringe a variáveis temporais e de articulação de ações, pois não se trata apenas de definir 
a responsabilidade por cada etapa do trabalho, de estabelecer a seqüência das ações, de programar a execução, de verificar a realização, como ocorre quando as fronteiras são fixas e os mecanismos tradicionais de coordenação são suficientes. Ficou evidenciado que a coordenação dos trabalhos nos sistemas tecnologicamente complexos abrange também outras dimensões: uma dimensão cognitiva, relativa à integração dos conhecimentos e habilidades para acompanhar e interpretar as tendências e variações das variáveis dos processos e para decidir como tratar situações não rotineiras; uma dimensão normativa, relativa à redefinição das regras e procedimentos de operação do aparato técnico, de intervenções de manutenção e, mesmo, de elaboração e execução de projetos de engenharia. Como no trabalho em processos contínuos mais de um domínio é envolvido em cada uma dessas dimensões, passam a existir co-responsabilidade, co-execução e compartilhamento do controle, fazendo com que as fronteiras se movam e se tornem interpenetrantes nessas interfaces entre os domínios. Então, há que se repensar os mecanismos de coordenação.

Uma prática bastante adotada é constituição de grupos compostos por pessoas com diferentes competências ou representantes dos segmentos organizacionais envolvidos, designados permanente ou temporariamente, para executar parte ou todo o trabalho. A prática observada nas empresas estudadas mostra que esses grupos podem oferecer bons resultados em atividades como planejamento e programação de manutenção, projetos, análise de eventos, soluções de problemas, monitoramento do desempenho de equipamentos, insumos e processos. Permitem reunir conhecimentos, buscar e analisar informações de cada domínio ali representado, para a determinação das causas de problemas, para definição de novos procedimentos de trabalho e elaboração de planos de ações que envolvem diferentes funções. Dessa forma, exercem papel de coordenação, nas dimensões cognitiva e normativa, podendo prosseguir na coordenação da execução das ações definidas.

$\mathrm{Na}$ maioria dos casos em que as ações envolvem mais de um segmento, foi mostrado que a liderança das ações é da Operação. Entretanto, deve haver flexibilidade para que essa liderança seja exercida pela área que detiver as competências necessárias ao andamento das ações. Por exemplo, a detecção de uma variação do sistema de produção pode ser da Operação ou da Manutenção, 
mas a análise das soluções possíveis pode ser liderada pela Engenharia, se ela possuir mais competência para tal. Como isso varia caso a caso, é difícil fixar regras antecipadamente sobre quem lidera ou coordena. Logo, essa deve ser uma decisão tomada em conjunto, a cada evento.

Nos capítulos 4 e 5 foram apresentadas e discutidas situações envolvendo os três domínios, Operação, Engenharia e Manutenção. A tabela 6.1 resume, algumas práticas, de coordenação observadas ou relatadas pelos entrevistados na pesquisa, que fogem aos mecanismos de coordenação identificados por Mintzberg.

\begin{tabular}{|c|c|c|}
\hline $\begin{array}{l}\text { Situações de } \\
\text { trabalho }\end{array}$ & Atividades / ações envolvidas & $\begin{array}{l}\text { Prática de } \\
\text { coordenação }\end{array}$ \\
\hline $\begin{array}{l}\text { Planejamento, } \\
\text { programação e } \\
\text { execução de } \\
\text { trabalhos de } \\
\text { manutenção }\end{array}$ & $\begin{array}{l}\text { Definição dos serviços prioritários, } \\
\text { análise dos riscos envolvidos, } \\
\text { planejamento dos trabalhos, } \\
\text { comunicação com todas as partes } \\
\text { envolvidas, coordenação da execução. }\end{array}$ & $\begin{array}{l}\text { Equipes constituídas por } \\
\text { profissionais dos } \\
\text { domínios participantes }\end{array}$ \\
\hline \multirow[t]{3}{*}{$\begin{array}{l}\text { Acompanhamento } \\
\text { rotineiro dos } \\
\text { processos de } \\
\text { produção }\end{array}$} & $\begin{array}{l}\text { Avaliação de desvios e tendências dos } \\
\text { parâmetros dos processos integrando } \\
\text { diferentes aspectos e abrangências } \\
\text { para orientar ações de curto prazo. }\end{array}$ & $\begin{array}{l}\text { Reuniões diárias de } \\
\text { produção }\end{array}$ \\
\hline & $\begin{array}{l}\text { Avaliação abrangente do desempenho } \\
\text { de partes dos processos e proposição } \\
\text { de melhorias. }\end{array}$ & Grupos temáticos \\
\hline & $\begin{array}{l}\text { Identificar variações reais e potenciais } \\
\text { dos processos, alertar e apoiar outros } \\
\text { domínios no controle das variações. }\end{array}$ & Interação direta \\
\hline $\begin{array}{l}\text { Eventos } \\
\text { imprevistos e } \\
\text { problemas da } \\
\text { produção }\end{array}$ & $\begin{array}{l}\text { Identificação de causas básicas e } \\
\text { estabelecimento de ações. }\end{array}$ & $\begin{array}{l}\text { Grupos de trabalho de } \\
\text { análise e solução }\end{array}$ \\
\hline $\begin{array}{l}\text { Mudanças } \\
\text { técnicas nos } \\
\text { processos }\end{array}$ & $\begin{array}{l}\text { Completude dos requisitos e } \\
\text { percepções envolvidos nas mudanças. }\end{array}$ & $\begin{array}{l}\text { Sistemática de } \\
\text { participação de } \\
\text { profissionais de } \\
\text { diferentes domínios nos } \\
\text { projetos de engenharia }\end{array}$ \\
\hline
\end{tabular}

Tabela 6.1 - Práticas de coordenação para organização do trabalho em processos contínuos. Fonte: elaborado pelo autor.

Assim, aos conceitos de projeto da teoria sociotécnica moderna, resumidos em quatro princípios (SITTER et al., 1997), é interessante que seja acrescentado o princípio proposto a seguir: 
O projeto de organização do trabalho deve incluir o estabelecimento de mecanismos de coordenação nas interfaces com fronteiras móveis e interpenetrantes das funções, subsistemas ou domínios organizacionais que, sem prejuízo dos enfoques tradicionais da coordenação - padronização, seqüência, cronologia e monitoramento de ações, possibilitem a integração dos saberes (dimensão cognitiva) e a redefinição conjunta de regras de produção (dimensão normativa). $O$ aprendizado constante dos processos, que necessita da integração dos saberes, e a redefinição de regras de produção são partes fundamentais do trabalho dos domínios organizacionais que atuam diretamente nos sistemas de produção complexos.

\subsection{REVISÃO DAS REGRAS PARA PROJETO ORGANIZACIONAL}

As regras para projeto organizacional (SITTER et al., 1997, SALERNO, 1999: 2007) são reelaboradas, tendo em vista a sua utilização para projetos em sistemas de produção contínuos:

\section{a) Definição dos processos}

Identificar os processos do sistema de produção e suas relações com outros sistemas da organização. Incluem-se dentre os processos não apenas os relativos à obtenção dos produtos $\mathrm{e}$ atendimento aos pedidos (desenvolvimento ou especificação de produtos, planejamento e controle da produção, fabricação, entrega etc.), mas aqueles que lhes dão sustentação, como manutenção, suprimento de insumos e melhoramento de processos. Considerar aspectos que transpassam os processos, como qualidade, preservação ambiental, segurança, custos, finanças e outros que forem considerados relevantes.

A definição dos processos inclui discutir a associação dos processos às estratégias da empresa, pontos fortes e fracos de cada processo, identificação de atividades, características, fatores e indicadores do desempenho dos processos e atividades. 


\section{b) Paralelização dos processos}

Definir as possibilidades para criação de fluxos paralelos no sistema de produção, isto é, realização de partes do processo de produção em mais de uma unidade. Com isso, impactos de variações no sistema de produção como as decorrentes de tipos diferentes de matéria-prima e fabricação de produtos especificações diferentes das usuais, ou ainda panes de equipamentos podem ter a propagação minimizada. Entretanto, as oportunidades de criação de fluxos paralelos nos sistemas de produção contínuos são restritas em razão dos equipamentos nesse tipo de processo serem, usualmente, dedicados e de alto custo. As oportunidades acontecem quando a concepção da fábrica prevê mais de uma unidade operacional do mesmo tipo ou há expansões das fábricas e novas unidades são construídas.

\section{c) Segmentação dos processos}

Cabe destacar quanto à segmentação dos processos, a importância da consideração das interferências dos aspectos transversais nos processos de obtenção dos produtos, pois eles podem introduzir outras fontes de variações no sistema de produção. Exemplos de situações decorrentes desses aspectos transversais são modificações nos processos de fabricação para adequação a novas exigências de mercado, a mudanças na legislação ambiental etc. Identificam-se assim interfaces organizacionais dos segmentos da Operação com outros processos e segmentos de outros domínios, que nem sempre podem ser internalizadas pela absorção dessas atividades pelos segmentos da Operação. Nesses casos, há que se incluir no projeto organizacional mecanismos de coordenação e comunicação para essas interfaces, o que será abordado nas etapas 7 e 8 destas regras para projeto.

\section{d) Identificação de competências necessárias}

Os conhecimentos e habilidades necessários a cada etapa dos processos do sistema de produção têm interferência direta na estruturação dos segmentos, pois em sistemas de produção complexos essas competências nem sempre estão 
disponíveis em um único segmento. Então, identificar as competências necessárias às atividades de execução e controle dos processos.

\section{e) Estruturação dos segmentos- foco na execução}

Trata-se de projetar a organização do trabalho internamente aos segmentos organizacionais anteriormente definidos. Por exemplo, como se organiza o trabalho nos grupos de operadores da refinaria de petróleo, levando em conta experiência, conhecimentos dos sistemas de equipamentos que aquele grupo opera, a divisão do trabalho entre atividades de campo e de monitoramento do processo pelo painel de controle (console do SDCD) (AULICINO, 1998). No presente estudo, o foco da discussão não é como os profissionais de um segmento se organizam, mas a organização do trabalho nos segmentos frente à necessidade de outros segmentos executarem processos ou atividades de forma integrada.

Esta etapa do projeto organizacional é baseada em definições relativas ao parâmetro estrutural de divisão do trabalho entre preparar, apoiar e produzir e ao parâmetro estrutural de especialização da execução.

Com base na segmentação dos processos, identificar atividades que devam ser executadas por outros segmentos da organização. A decisão pode levar em conta fatores como a disponibilidade de recursos físicos e humanos em cada segmento, conhecimentos e habilidades necessários, tempo de ciclo das atividades etc.

O mesmo raciocínio deve ser aplicado a situações não rotineiras, para as quais pode ser necessária uma organização do trabalho diferente da utilizada no dia-a-dia, específica para cada evento. O exemplo da colocação em operação da torre da Fertilizantes, apresentado anteriormente, ilustra bem a aplicação desse parâmetro ao tratamento de eventos.

Pode não ser suficiente a divisão do trabalho nas três subfunções, de preparar, apoiar e produzir, levando a que essas subfunções sejam subdivididas, com a participação de mais de um segmento em cada uma delas. É o caso da execução de intervenções de manutenção no sistema de produção, tomando-se por execução a realização do reparo, compreendendo tarefas de remoção de peças defeituosas, instalação e ajuste de peças novas, soldagem etc, pelo pessoal da Manutenção. Nesse caso, a subfunção de preparação, pode ter tanto o aspecto de preparação da 
Manutenção para a execução dos serviços, que inclui a busca de ferramentas, construção de acessos - tipo andaimes -, isolamento do local etc., como da preparação do sistema de produção para que a intervenção ocorra, feita pela Operação. Essa preparação do sistema de produção pode incluir a colocação em funcionamento de equipamentos reservas para que o equipamento defeituoso sofra intervenção sem prejudicar a continuidade da produção, o que é feito através de manobras realizadas pela Operação. Para que o pessoal da Manutenção possa começar a execução, é necessário que o equipamento que vai ser reparado seja esgotado, descontaminado se processar fluido tóxico, combustível ou explosivo, o que geralmente é feito através de procedimentos operacionais. Outros aspectos da preparação, mais relacionados às tarefas do pessoal da Manutenção podem incluir tarefas de aprovisionamento de peças de reposição, com a verificação de existência de sobressalentes, compra ou requisição no almoxarifado, transporte e acondicionamento em local próximo à realização do serviço etc.

A estruturação interna dos segmentos deve ser abordada, também, pela ótica da desconcentração das atividades. Por exemplo, atividades de manutenção que podem ser realizadas pelos operadores e não apenas pelos oficiais de manutenção, análise do desempenho dos processos pela Operação e/ou pela Engenharia, realização de compras pelo usuário e não apenas por um órgão de compras especializado etc.

As vantagens mais visíveis são agilidade e redução de interfaces com outros segmentos organizacionais (estas são propagadoras de variabilidades). Algumas possíveis desvantagens são a falta de preparo para lidar com essas atividades, principalmente se apresentarem complicações não esperadas, a perda de escala (por exemplo, a realização de diversas compras do mesmo produto para o mesmo fornecedor ao mesmo tempo por grupos diferentes).

Esse tipo de desconcentração de atividades é abordado por Marx (1997) ao discutir os graus de autonomia de grupos de trabalho de operários no sistema de produção. Nessa proposta grupos de trabalhadores semi-autônomos da produção podem desempenhar atividades tradicionalmente atribuídas a níveis hierárquicos maiores, como controle de ponto e organização de treinamentos, e de atividades usualmente de outros segmentos especializados, como a realização de pequenas compras e contatos com clientes. 
Cumpre destacar que não se trata de debater a departamentalização (Operação, Manutenção e Engenharia), mas organizar o trabalho tendo em conta as necessidades de participação e interfaces entre essas áreas, prevendo-se, inclusive, mecanismos de coordenação entre os diferentes segmentos e domínios executantes.

\section{f) Estruturação dos segmentos - foco no controle}

Se nas duas etapas anteriores a segmentação do sistema de produção se fez no sentido dos segmentos maiores para as suas divisões (top-down), a alocação das atividades de controle se faz no sentido bottom-up, ou seja, dos níveis mais próximos à execução para os níveis maiores da estrutura organizacional. A exemplo da estruturação dos segmentos quanto às atividades de execução, Sitter, Dankbaar e Hertog $(1994,1997)$, Salerno $(1999,2007)$ e Aulicino (1998) discutiram as atividades de controle quanto à seleção e alocação das atividades de controle. Nesta pesquisa, o foco são as situações em que o controle é transferido para outros domínios e segmentos ou compartilhado entre as unidades organizacionais que atuam no sistema de produção.

As definições acerca do controle acontecem segundo os parâmetros estruturais alocação das funções de controle dos processos, especialização do controle, diferenciação do controle e divisão das funções de controle. Os fatores que implicam na determinação desses parâmetros com relação à participação de outros segmentos além do que executa o processo são apresentados a seguir.

Caso a abrangência do controle extrapole os limites do sistema de produção, avaliar a alocação das atividades correspondentes em órgão com abrangência compatível com a do controle. Por exemplo, o da empresa de fertilizantes que optou por um único órgão, centralizado para o PCP de todos os sistemas de produção da empresa.

Considerar as atividades de controle sob os seguintes aspectos:

Especialização: considerar a necessidade ou conveniência de criar segmentos especializados em razão de conhecimentos técnicos específicos, locais e equipamentos apropriados, natureza e duração das atividades. É o caso dos processos em que as atividades de controle dependem de ensaios de laboratório. 
Então, pode-se optar ou por um segmento de laboratório especializado na realização de ensaios, cujos resultados são usados para regulagem dos processos de fabricação, ou pela realização dos ensaios pelos próprios operadores. Outro exemplo visto foi alocação do PCP na Engenharia, tendo em vista dentre outras razões, o uso de modelos matemáticos de processos para efetuar o planejamento e programação da produção. Nesse caso, preferiu-se alocar a atividade de planejamento, programação e controle de produção em um segmento com especialização em engenharia de processo, dentro do domínio organizacional da Engenharia, ao invés de ficar no domínio que executa o programa de produção, que é a Operação.

Natureza do controle: diferenciar as atividades de controle segundo abrangência, complexidade e ciclo de tempo. Por exemplo, a regulagem física das variáveis de produção demanda ações de curtíssimo/curto prazo, de certo grau de complexidade, através de atuação no funcionamento de equipamentos ou subsistemas (conjuntos de equipamentos realizam certa parte do processo de fabricação), em resposta a variações surgidas ou para promover variações desejadas. Por vezes a análise das causas de variações não desejadas, como a dificuldade persistente de se manter certas variáveis sob controle, é mais complexa. Ela pode requerer conhecimentos mais profundos das reações físico-químicas, de engenharia de materiais, reavaliações do projeto dos equipamentos do ponto de vista dos processos físicos e químicos, do dimensionamento mecânico e outros. As causas podem estar em outros locais ou processos do sistema de produção e as possíveis soluções podem ter implicações em todo o sistema de produção. Esse tipo de análise pode ter tempo longo de realização. As soluções e melhorias a serem introduzidas nos processos podem exigir a elaboração de simulações e projetos de engenharia. Então, tomandose o ciclo de controle, pode se pensar a alocação das funções de detecção e percepção, avaliação e ação em segmentos diferentes segundo abrangência, complexidade e ciclo de tempo.

Compartilhamento do controle: levar em conta que há pontos de monitoramento do processo de fabricação que são comuns a outros segmentos. Por exemplo, o monitoramento das condições físicas e de funcionamento de equipamentos interessa tanto ao domínio operacional como ao de manutenção, podendo ser monitorados por segmentos dos dois domínios, com abordagens diferentes, porém 
complementares. As ações de controle decorrentes também podem ser tomadas em um ou outro segmento ou em todos ao mesmo tempo. Por exemplo, a detecção de problemas em uma válvula de controle de pressão ou de segurança, pode implicar em operar o processo a pressões mais baixas (ação da Operação segundo cálculo efetuado pela própria Operação ou pela Engenharia, ao mesmo tempo em que se prepara o reparo do problema pela Manutenção). Então importa entender quais ações de controle se interligam ou complementam, alocando-as de modo conveniente nos segmentos organizacionais, prevendo compartilhamento das informações e mecanismos de coordenação. Estes dois assuntos, sistema de informações e mecanismos de coordenação, serão abordados a seguir.

\section{g) Mecanismos de Coordenação}

Estabelecer os mecanismos adequados de coordenação intra e entre funções, considerando tanto a abordagem tradicional de coordenação, de articulação de ações e atividades, como a abordagem aqui apresentada, que trata das dimensões cognitiva e normativa do trabalho, quando as fronteiras se movem e se interpenetram. Considerar o desenho adequado às situações normais (rotineiras) e as situações não rotineiras, como os eventos imprevistos.

\section{h) Detalhamento da Tecnologia de Processo}

Avaliar alternativas tecnológicas e elaborar projeto detalhado dos equipamentos e dos sistemas de controle de processo considerando as definições feitas para a estrutura organizacional.

\section{i) Estruturação do Sistema de Informação - Espaços de Comunicação}

O projeto da estrutura de informação não é objeto da presente pesquisa. Mas cabe salientar que o sistema de informação deve ser pensado em decorrência das etapas anteriores. A disponibilidade de informação confiável, no momento certo, para as pessoas certas é condição para o bom funcionamento da organização.

Não basta projetar e implantar um bom sistema de informações. Juntamente com o sistema de informação, a criação de espaços de comunicação é importante para a 
dinâmica da organização. Os trabalhos de Zarifian e Aubé (2002), Zarifian (2006) e Salerno (1999) tratam bem a questão da comunicação. Esses autores enfocam principalmente os espaços e formas de comunicação para possibilitar participação mais ampla dos operários na execução e controle dos processos, visando aumentar a flexibilidade e agilidade nas organizações.

Entretanto, cabem algumas observações quanto ao foco da comunicação, tendo em vista o tema e os dados obtidos desta pesquisa. Sob o aspecto das interfaces, importa aumentar o conhecimento acerca dos aspectos transversais aos processos (confiabilidade, qualidade, segurança etc.) visando ação integrada entre os segmentos. Em particular, estabelecer espaços para discussão e deliberações a respeito da participação da Operação e da Manutenção nos projetos da Engenharia, do apoio da Engenharia às demandas técnicas da Operação e Manutenção, das interações entre Operação e Manutenção.

Em suma, além de possibilitar a intercompreensão dos profissionais que atuam nos diferentes domínios, os mecanismos de coordenação e os espaços de comunicação constituem elos entre os ciclos e abrangências diferentes de atuação dos domínios organizacionais. Permitem a compatibilização dos objetivos dentro da organização e a colocação em comum das competências dominadas por cada segmento.

A tabela 6.2 mostra de forma resumida as etapas de projeto apresentadas e as relações entre elas.

1. Definição dos Processos do Sistema de produção

- Processos de obtenção dos produtos e os que lhe dão suporte

- Identificar os aspectos transversais aos processos

2. Paralelização dos Processos

- criação de fluxos paralelos

3. Segmentação dos Processos

- iniciar no sentido top-down

- identificar variabilidades (na execução dos processos e aspectos

transversais)

- internalizar interfaces

- identificar interfaces remanescentes, inclusive com outros domínios

Tabela 6.2 (continua) 


\begin{tabular}{|c|c|}
\hline \multirow{2}{*}{$\begin{array}{l}\text { 4.Identificação de } \\
\text { Competências - } \\
\text { conhecimentos } \\
\text { e habilidades } \\
\text { necessários à } \\
\text { execução e ao } \\
\text { controle }\end{array}$} & $\begin{array}{l}\text { 5. Estruturação dos Segmentos - Execução } \\
\text { Atividades do processo realizadas por outros } \\
\text { segmentos e domínios organizacionais: } \\
\text { - trabalhos rotineiros e não rotineiros - eventos } \\
\text { - atividades que sejam divididas em preparação, } \\
\text { apoio e execução } \\
\text { - conveniência ou necessidade de execução por } \\
\text { outros }\end{array}$ \\
\hline & $\begin{array}{l}\text { 6. Estruturação dos Segmentos - Controle } \\
\text { - alocar atividades no sentido bottom-up } \\
\text { - especialização do controle: competências e } \\
\text { condições específicas } \\
\text { - natureza do controle: detecção, avaliação e } \\
\text { ação x abrangência, complexidade e ciclo } \\
\text { - compartilhamento do controle: integração do } \\
\text { controle de aspectos comuns ou interligados }\end{array}$ \\
\hline \multirow{2}{*}{\multicolumn{2}{|c|}{$\begin{array}{l}\text { 7. Mecanismos de Coordenação } \\
\text { - ciclos, abrangências, objetivos, competências - fronteiras móveis e } \\
\text { interpenetrantes } \\
\text { - dinâmica organizacional: eventos } \\
\text { - espaços de comunicação } \\
\text { 8. Detalhamento da Tecnologia de Processo }\end{array}$}} \\
\hline & \\
\hline 9. Sistema de Intor & \\
\hline
\end{tabular}

Tabela 6.2 (conclusão) - Etapas para o projeto organizacional integrado para sistemas de produção contínua. Elaborado pelo autor.

\subsection{COMPARAÇAO ENTRE A TEORIA EXISTENTE E AS PROPOSIÇÕES EFETUADAS}

De modo resumido, a tabela 6.3 mostra uma comparação entre a teoria existente para projeto organizacional, como apresentada por Sitter et al. $(1994$; 1997) e Salerno $(1999 ; 2007)$ e as propostas para que a teoria contemple em seus conceitos e regras as necessidades para elaboração do projeto organizacional para sistemas de produção por processos contínuos. 


\begin{tabular}{|c|c|}
\hline $\begin{array}{l}\text { Regras para projeto organizacional } \\
\text { - sociotecnologia moderna (Sitter et } \\
\text { al., 1994; 1997; Salerno, 1999; 2007) }\end{array}$ & $\begin{array}{l}\text { Contribuições: mudanças } \\
\text { propostas nas regras para projeto } \\
\text { organizacional }\end{array}$ \\
\hline $\begin{array}{l}\text { 1.Definição dos Processos do Sistema } \\
\text { de produção. }\end{array}$ & $\begin{array}{l}\text { Além dos processos de fabricação, } \\
\text { inclui processos de apoio } \\
\text { (conservação e reparos, projetos de } \\
\text { melhorias etc). }\end{array}$ \\
\hline $\begin{array}{l}\text { 2. Paralelização dos Processos: } \\
\text { identificação de variabilidades e } \\
\text { criação de fluxos paralelos. }\end{array}$ & Inalterado. \\
\hline $\begin{array}{l}\text { 3. Segmentação dos Processos: } \\
\text { sentido top-down; internalização de } \\
\text { interfaces. }\end{array}$ & $\begin{array}{l}\text { Inclui a identificação de atividades e } \\
\text { eventos-tipo que demandem } \\
\text { competências de outros domínios; } \\
\text { estabelecer atividades equivalentes } \\
\text { em outros domínios. }\end{array}$ \\
\hline 4. Não existe esta etapa & $\begin{array}{l}\text { Identificação de competências } \\
\text { necessárias à execução dos } \\
\text { processos e controle. }\end{array}$ \\
\hline 5. Não existe esta etapa & $\begin{array}{l}\text { Estruturação do trabalho nos } \\
\text { segmentos organizacionais: } \\
\text { parâmetros estruturais de execução e } \\
\text { desconcentração. Na teoria original } \\
\text { esta etapa está incluída na } \\
\text { segmentação. }\end{array}$ \\
\hline $\begin{array}{l}\text { 6. Estruturação do controle: alocação } \\
\text { bottom-up dos ciclos de controle }\end{array}$ & $\begin{array}{l}\text { Considera as situações de } \\
\text { compartilhamento do controle com } \\
\text { outros domínios. }\end{array}$ \\
\hline 7. Não existe esta etapa. & $\begin{array}{l}\text { Estabelecer mecanismos de } \\
\text { coordenação do trabalho integrado } \\
\text { dos domínios organizacionais - } \\
\text { considerar dimensões cognitiva e } \\
\text { normativa. }\end{array}$ \\
\hline $\begin{array}{l}\text { 8. Projeto detalhado da tecnologia de } \\
\text { processo. }\end{array}$ & $\begin{array}{l}\text { Foco no detalhamento dos sistemas } \\
\text { de controle de processo. }\end{array}$ \\
\hline $\begin{array}{l}\text { 9. Projeto do sistema de informações; } \\
\text { criação de espaços de } \\
\text { comunicação/negociação. }\end{array}$ & Inalterado. \\
\hline
\end{tabular}

Tabela 6.3 - Quadro comparativo entre a teoria para projeto organizacional de base sociotécnica moderna e as proposições para contemplar processos contínuos de produção. Elaborado pelo autor. 


\section{CONSIDERAÇÕES FINAIS}

Nesta pesquisa foi discutido um problema de ordem conceitual-metodológica: como organizar as interfaces entre as funções que atuam nos sistemas de produção por processos contínuos, onde a Engenharia e a Manutenção interferem diretamente na operação dos sistemas, junto com a própria Operação, que por sua vez participa frequentemente das atividades a princípio do domínio da Engenharia e da Manutenção, assim como a Manutenção também participa de atividades que seriam, em primeira análise, dos outros domínios. A identificação desse problema tem um aspecto prático: a experiência de vários anos em produção por processos contínuos junto com o estudo da teoria sociotécnica moderna de projeto organizacional permitiu a este autor identificar que essa teoria não tratava todas as características organizacionais dos processos contínuos. Era preciso considerar que as fronteiras entre as funções que atuam no sistema de produção muitas vezes se sobrepõem.

Com relação à pesquisa efetuada para abordar o problema, cabem algumas considerações a respeito dos dados levantados. Os dois casos estudados, uma refinaria de petróleo e uma fábrica petroquímica de produtos para fertilizantes, são bastante representativos de produção por processos contínuos, pois além de típicos desse tipo de produção, tratam-se de empresas de destaque nas respectivas indústrias. Acrescente-se que as fábricas onde foram levantados os dados da pesquisa estão em funcionamento há vários anos, acumulando larga experiência do trabalho nesse tipo de sistema produtivo. Por essa razão, observados os requisitos metodológicos da pesquisa, os dados levantados acerca das interfaces entre as funções (ou domínios organizacionais) que atuam no sistema de produção são bastante significativos.

Esses dados permitem evidenciar situações em que Operação, Engenharia e Manutenção agem conjuntamente no sistema de produção sem se aterem a uma divisão rígida de fronteiras, mas em que a participação de cada um se ajusta caso a caso. Essas constatações são importantes porque demonstram que em diversas ocasiões as fronteiras entre Operação, Manutenção e Engenharia não são fixas. Mais do que isso, diversas atividades de execução e de controle realizadas por 
essas funções se sobrepõem, o que significa que as fronteiras desses domínios organizacionais se movem e penetram umas nas outras.

Uma conclusão imediata é que o projeto organizacional para processos contínuos deve considerar dois tipos de fronteiras nas interfaces dos domínios organizacionais: as fronteiras fixas que definem os domínios e segmentos da estrutura organizacional, e as fronteiras móveis e interpenentrantes. Estas, pode se dizer, estão mais ligadas à dinâmica da organização, ou seja, como a estrutura se move para dar conta de situações que não podem ser resolvidas a contento dentro dos limites de um único domínio organizacional. Assim, a teoria de projeto organizacional sociotécnico moderno foi discutida, fazendo-se as considerações necessárias ao tratamento das fronteiras móveis e interpenetrantes.

As principais contribuições são de cunho teórico-conceitual e metodológico. Foi introduzida a idéia de fronteira móvel e interpenetrante que explica melhor os problemas de organização em ambientes complexos de produção. Esse conceito tende a ser extremamente útil não apenas para processos contínuos, como para sistemas de produção integrados, flexíveis e automatizados. Ou seja, sistemas onde os aspectos execução e controle do sistema de produção envolvam diferentes funções ou domínios organizacionais.

A introdução das fronteiras móveis e interpenetrantes levaram à necessidade de tratar a questão da coordenação. Conceitualmente, a Sociotecnologia Moderna não considerava a coordenação. Enquanto os mecanismos tradicionais de coordenação se voltam para a concatenação temporal e seqüencial do trabalho dividido entre diferentes unidades organizacionais, foram propostas práticas de coordenação voltadas à integração dos domínios organizacionais quando as fronteiras se interpenetram. São práticas voltadas à interação entre as funções com base nos conhecimentos e nas habilidades dominados e desenvolvidos por elas. $O$ estabelecimento de tais mecanismos de coordenação deve fazer parte do projeto organizacional.

É interessante destacar alguns conceitos da teoria proposta:

Na determinação dos parâmetros da estrutura de execução é levada em conta a coexecução - quando uma atividade de execução é realizada conjuntamente por mais de um domínio organizacional. 
Já para os parâmetros estruturais relativos à estrutura de controle é considerada a existência de compartilhamento do controle por domínios diferentes - quando um mesmo aspecto do sistema de produção é controlado por mais de uma função ou quando o controle de aspectos inter-relacionados faz com que as decisões sejam tomadas conjuntamente, por exemplo, manutenção de equipamentos e qualidade de produtos.

Para tratar os mecanismos de coordenação foi proposto o seguinte princípio para projeto: estabelecer mecanismos de coordenação para as interfaces com fronteiras móveis e interpenetrantes que possibilitem a integração dos saberes e a redefinição conjunta das regras de produção.

Com respeito à metodologia de projeto, considerar as seguintes regras:

Identificação de competências - paralelamente ao desenho das estruturas de execução e controle é necessário prever identificar situações onde a participação de outros domínios seja requerida, em função das habilidades e conhecimentos necessários e disponíveis;

Estruturação dos segmentos - estruturar atividades de processos que são alocadas a outros segmentos e domínios organizacionais que o executor principal daquele processo ou daquela parte do processo;

Mecanismos de Coordenação - como desdobramento do princípio de mecanismos de coordenação, o estabelecimento desses mecanismos deve ser uma das etapas do projeto organizacional.

Cabe ressaltar que a teoria sociotécnica de projetos prevê a seleção de tecnologia no caso dos equipamentos do sistema de produção - como uma das etapas do projeto organizacional. Nos processos como refino de petróleo e fertilizantes (petroquímica), o investimento é muito alto, a tecnologia de processos dominada por poucas empresas e há poucas possibilidades de escolha entre alternativas. Usualmente a seleção de tecnologia se faz nas etapas iniciais dos projetos de investimento, pois determina o desenvolvimento de todo o projeto de engenharia, que tem ciclo longo. A postura sugerida nos casos práticos é, quando não houver alternativas, explicitar as restrições que a tecnologia coloca para o projeto organizacional, visando discutir possibilidades de adequação com o fornecedor e 
conceber e parametrizar sistemas de controle compatíveis com as necessidades organizacionais.

A pesquisa foi toda desenvolvida em empresas com processos contínuos típicos. Os dois casos estudados são amplamente representativos desse tipo de processo, não se vislumbrando, assim, problemas de generalização para demais empresas de processos contínuos, principalmente as de processo mais complexo.

Contudo, surge a questão de até que ponto as considerações aqui desenvolvidas podem fazer sentido para outros tipos de processo de trabalho, Evidentemente, para conclusões embasadas, seria necessário proceder a uma pesquisa específica - é como se, num experimento químico, mudassem as condições de contorno. Numa primeira análise, pode se levantar a hipótese, plausível, de que questões de interface organizacional como as discutidas aqui ocorrem em vários outros tipos de processos, e não só industriais. Em sistemas de serviços pode haver grande superposição - por exemplo, entre atendimento e retaguarda, entre o comercial e o técnico (ou entre vendas e engenharia), e assim por diante. Ou seja, há boa possibilidade de que os desenvolvimentos desta tese possam ser válidos num universo maior. É uma boa sugestão para pesquisas futuras.

$\mathrm{Na}$ mesma direção, pode se pensar as fronteiras de um sistema de produção estendido, qual seja, as fronteiras entre produtor, fornecedores, cliente, prestadores de serviço.

Por fim, como a contribuição teórico-metodológica aqui apresentada resultou do estudo de casos, é justo perguntar de que maneira essa contribuição pode repercutir na prática das organizações pesquisadas. Um ponto observado durante a pesquisa, embora não fosse objeto dela, foi que essas empresas não têm histórico, ao menos recente, de desenvolver projetos organizacionais, na forma prescrita pela literatura de referência. As formas de organização existentes foram se moldando pelo ajuste dos arranjos organizacionais previamente existentes e adoção de práticas tidas como bem sucedidas em outras fábricas similares. Entretanto, há expectativa por parte deste autor de que a explicitação dos conceitos relativos às características organizacionais do trabalho em processos contínuos influencie os ajustes que venham a ser feitos nessas empresas, destacando a importância dos mecanismos de coordenação para fronteiras móveis e interpenetrantes. 
Dentro da sua condição de observador participante, este autor tem tido a oportunidade de vivenciar situações em que as fronteiras organizacionais se movem e interpenetram. São oportunidades para colocação em prática dos conceitos deste estudo, opinando no estabelecimento de mecanismos de coordenação, participando da análise de eventos da produção, participando da avaliação de resultados de desempenho do sistema de produção, atuando para que nos procedimentos de gestão do sistema de produção, as interfaces com fronteiras móveis e interpenetrantes sejam previstas.

Quanto à utilização da metodologia de projeto organizacional proposta, de imediato há intenção de aplicá-la para reorganização do domínio da Engenharia na Refinaria de Cubatão. 


\section{REFERÊNCIAS BIBLIOGRÁFICAS}

AULICINO, MARCELO C. Elementos para Projeto de Organização do Trabalho na Operação de Processos Contínuos: Considerações a Partir de um Estudo de Caso. Dissertação (Mestrado). Departamento de Engenharia de Produção, Escola Politécnica, Universidade de São Paulo, São Paulo, 1998.

$\mathrm{BIAZZI} \mathrm{Jr,} \mathrm{FABIO.} \mathrm{O} \mathrm{trabalho} \mathrm{e} \mathrm{as} \mathrm{organizações} \mathrm{na} \mathrm{perspectiva} \mathrm{sócio-técnica.}$ Revista de Administração de Empresas. v. 34, n.1, p.30-7, jan./fev., 1994.

BONI, VALDETE; QUARESMA, SÍLVIA J. Aprendendo a entrevistar: como fazer entrevistas em Ciências Sociais. Revista Eletrônica dos Pós-Graduandos em Sociologia Política da UFSC. v. 2, n. 1 (3), janeiro-julho/2005, p. 68-80, www.emtese.ufsc.br.

BOUYER, GILBERT C.; SZNELWAR, LAERTE I. Análise Cognitiva do Processo de Trabalho em Sistemas Complexos de Operações. Ciências \& Cognição (UFRJ), v.4, p. 2-24, 2005.

CHERNS, ALBERT. Using the social sciences: The principles of sociotechnical design. London: Routledge \& Kegan Paul, 1979. cap.16, p.30-40.

DANIELLOU, F. L'operateur, la vanne, l'ecran: l'ergonomie des salles de contrôle. Paris, Laboratoire d'Ergonomie, Conservatoire National des Arts e Metiers, 1986.

DUARTE, FRANCISCO J. C. M. A Análise Ergonômica do Trabalho e a Determinação de Efetivos; estudo da modernização tecnológica de uma refinaria de petróleo no Brasil. Tese (Doutorado). COPPE / Universidade Federal do Rio de Janeiro. Rio de Janeiro, 1994. 
EIJNATTEN, FRANS M. VAN; ZWAAN, AD H. VAN DER. The Dutch IOR Approach to Organizational Design: An Alternative to Business Process Re-engineering? Human Relations, v.51, p. 289, 1998.

EISENHARDT, KATHLEEN M. Building theories from case study research. The Academy of Management Review, 14 v, n. 4, p.532-550, Oct. 1989.

FERREIRA, LEDA L.; IGUTI, APARECIDA M. O trabalho dos petroleiros: perigoso, complexo, contínuo e coletivo. São Paulo: Scritta, 1996.

FERRO, J. R.; TOLEDO, J. C.; TRUZZI, M. S. Automação do Trabalho em Indústrias de Processo Contínuo. Revista Brasileira de Tecnologia. Brasília, v.18(1), jan., 1987.

FLEURY, AFONSO C. C.; VARGAS, NILTON. Organização do trabalho: uma abordagem interdisciplinar. São Paulo: Atlas, 1983.

GRATTON, LYNDA; VOIGT, ANDREAS; ERICKSON, TAMARA J. Bridging fault lines in diverse teams. Sloan Management Review, Summer, 2007, v. 48, n. 4, p.22-29.

INOMATA, M.; SATO, K. YAMADA, Y.; HAJIME, S. Engineering firm has designed refinery in the future. Oil \& Gas Journal, April, 1997.

KAPLINSKY, RAPHAEL. Automation: the tecnology and society. Longman, Harlow, UK, 1984.

KHURANA, ANIL. Managing complex production processes. Sloan Management Review. Winter, p.85-97, 1999. 
LAZZARINI, Sérgio G. Estudo de Caso: Aplicabilidade e Limitações do Método para Fins de Pesquisa. Econ. Empresa, V.2, n.4, p.17-26, out/dez 1995.

LIMA, EDSON P.; LEZANA, A. G. R. Desenvolvendo um framework para estudar a ação organizacional: das competências ao modelo organizacional. Gestão \& Produção, v.12, p. 177-190, mai-ago. 2005.

MINTZBERG, HENRY. Structure in fives: designing effective organizations. Englewood Cliffs, Prentice Hall, 1993.

MARX, ROBERTO. Trabalho em grupos e autonomia como instrumentos da competição. São Paulo: Atlas, 1997.

MOUBRAY, JOHN. Manutenção Centrada em Confiabilidade. Trad. Kleber Siqueira. Aladon Ltd, Lutterworth, Inglaterra, 2000.

NAGAO, SÉRGIO K. Manutenção Industrial: Análise, Diagnóstico, Propostas de Melhoria em Indústrias de Processo. Dissertação (Mestrado) - Escola Politécnica, São Paulo. Universidade de São Paulo, 1998.

NAKANO, DAVID N. Dois Estudos de Caso Sobre a Centralização e Descentralização de Atividades de Engenharia. Dissertação (Mestrado) - Escola Politécnica, São Paulo. Universidade de São Paulo, 1997.

PAVA, CALVIN H. P. Managing new office technology. New York: The Free Press, 1983.

PLONSKI, GUILHERME A. Empresas de Serviços de Engenharia no Brasil: do CAD à Engemática. Tese (doutorado). Departamento de Engenharia de Produção. Escola Politécnica. Universidade de São Paulo. São Paulo,1986. 
RAMOS FILHO, AMÉRICO C. A evolução tecnológica e a gestão do trabalho na indústria de processo: o caso da Petrobrás. Dissertação (Mestrado). Pontifícia Universidade Católica do Rio de Janeiro, Rio de Janeiro, 1997.

SALERNO, MARIO S. Reconfigurable organization to cope with unpredictable goals. Proceedings (CD-ROM), International Conference of Production Research ICPR 19, Santiago, 2007

Projeto de organizações integradas e flexíveis: processos, grupos e gestão democrática via espaços de comunicação - negociação. São Paulo: Atlas, 1999.

Projeto Organizacional e Trabalho em Grupo na Produção. In Workshop Implementação de Novas Formas de Organização do Trabalho, São Paulo, 15-18 de agosto, 1995.

Flexibilidade, organização e trabalho operatório: elementos para análise da produção na indústria. Tese (Doutorado). Departamento de Engenharia de Produção, Escola Politécnica. São Paulo. Universidade de São Paulo, 1991.

SHOOK, DAVID. Best practices improve control system performance. Oil \& Gas Journal, Oct. 9. 2006, pg. $52-59$.

SITTER, ULBO L.; HERTOG, J. FRISO; DANKBAAR, BEN. From complex organizations with simple jobs to simple organizations with complex jobs. Human Relations, v. 50, n. 5, 1997.

Designing Simple Organization and Complex Jobs. Working Paper, 2/94-012. Merit, 1994. 
THIOLLENT, MICHEL. Pesquisa - ação nas organizações. São Paulo: Atlas, 1997.

WOODWARD, J. Organização Industrial - Teoria e Prática. São Paulo: Atlas, 1977.

WORLEY, C.G.; LAWLER III, E. E. Designing organizations that are built to change. Sloan Management Review, v. 48, n. 1, Fall 2006, p. 19-23.

VELTZ, PIERRE. Le nouveau monde industriel. Paris: Gallimard, 2000.

VELTZ, P.; ZARIFIAN, P. Vers de Noveaux Modéles d'Organization? Sociologie de Travail, v. 35, n. 1, p.3-25, 1993.

VOSS, CHRIS; TSIKRIKTSIS, NIKOS; FROHLICH, MARK. Case research in operations management. International Journal of Operations \& Production Management, v. 22, n. 2, 2005, p. 195-219.

YIN, Robert K. Case Study Research - Design And Methods. Thousand Oaks California, Sage Publications, 1994.

ZARIFIAN, PHILLIPE; AUBÉ, NATHALIE. Cahier des Charges de l'Organization Qualificante et Flexible. LATTS-CERTES, Ecole Nationale des Ponts et Chaussées, Paris, 1992.

ZARIFIAN, PHILIPPE. Travail et communication: essai sociologique sur le travail dans la grande entreprise industrielle. Paris: PUF, 1996. 


\section{ANEXO 1 \\ ROTEIRO DAS ENTREVISTAS}

\section{Dados dos Entrevistados}

\section{Entrevista}

1. Estrutura e objetivos da Operação (para gerentes da Operação)

2. Estrutura e objetivos da Manutenção (para gerentes da Manutenção)

3. Estrutura e objetivos da Engenharia (para gerentes da Engenharia)

\section{Identificação e relevância das interfaces Engenharia / Produção /} Manutenção:

a) variabilidades do sistema, eventos e interfaces;

b) soluções de problemas e melhorias;

c) projetos;

d) controle do sistema de produção;

e) outros;

f) curto $X$ longo prazo; rotina $X$ eventos significativos.

5. Ações, mecanismos, práticas existentes, estruturas com relação às interfaces

a) Primeira Variável (natureza das interfaces)

- situações não rotineiras: como são tratadas? Quem assume a liderança? Que formas de organização são adotadas? O que não funciona bem? O que funciona bem?

- Situações rotineiras: há estruturas para essas ocasiões? Quem lidera e decide? Por quê? Quais os espaços e fóruns criados?

- Com relação ao ciclo dos processos (ciclo longo X ciclo curto): há diferenças no tratamento? 
b) Segunda Variável: paralelização e segmentação das atividades entre Operação, Manutenção e Engenharia

- quem controla ou executa o que?

- incorporação versus separação de engenheiros e especialistas da manutenção aos órgãos de produção: qual a estrutura adotada? Por quê?

- agilidade na resposta a variabilidades do sistema de produção;

- maior transferência de conhecimento entre os profissionais de cada uma dessas áreas;

- deterioração dos trabalhos e da visão de médio e longo prazo em razão da priorização dos problemas de curto prazo;

- perda de especialização e de conhecimento dos engenheiros em razão do foco no curto prazo;

- outros?

c) Terceira Variável: diferenciação da execução

- Há separação de atividades entre o pessoal da operação, como preparação e execução?

- Essa separação se estende aos outros domínios?

- Idem para manutenção

- Idem para engenharia

d) Quarta Variável: especialização da execução

- Há limites de conhecimento do processo de produção que são supridos pela Engenharia e pela Manutenção?

- Há atividades da produção que, por necessidade de conhecimento, são alocadas a outros subsistemas, com a participação da Engenharia e da Manutenção?

e) Quinto Variável separação das funções de execução e controle; Sexta Variável: especialização do controle.

- Como é obtida a dirigibilidade do sistema de produção? 
Nota: controle é a capacidade de promover variações no sistema de produção, é a capacidade de lidar com variabilidades. Inclui o conceito de pilotar o sistema de produção.

- Qual é o papel de cada uma das áreas (Operação, Manutenção e Engenharia) na pilotagem do sistema de produção?

- Há papel preponderante ou liderança de alguma dessas áreas na questão da dirigibilidade?

- Quais os mecanismos e práticas para o controle?

- Quais os limites para a atuação dos operadores na pilotagem? Por quê?

- Qual é a "autoridade" da Manutenção e da Engenharia sobre o sistema de produção sob a ótica da pilotagem?

- Como é a atuação da engenharia e da manutenção em relação à autoridade e autonomia dos operadores sobre o sistema de produção? Há problemas nessa interface?

- SDCD e outros sistemas automatizados, incluindo controles avançados: como são tratados? Pode-se dizer que o engenheiro também opera o sistema por meio do controle avançado? Quem define o que, qual o papel, limites de autoridade de cada um, como são divididas as responsabilidades?

- Como são resolvidos os conflitos entre Operação, Engenharia e Manutenção? (Conflitos são posições diferentes em razão da possível diferença de objetivos)

- Como é feita a passagem de conhecimentos entre essas áreas?

- Descrever e analisar como ocorre o tratamento dos eventos, considerando o papel das três áreas e de outras que porventura venham a participar.

f) Sexta Variável: diferenciação do controle

- Há diferenças de nível de controle em relação ao sistema de produção (estratégico, tático e operacional)?

- Como se situam a Operação, Engenharia e Manutenção em relação a esses níveis?

\section{Problemas e dificuldades nas interfaces}

a) Quanto à comunicação entre Engenharia e Manutenção com a Operação. Considerar em relação á gerência, supervisão e operadores. 
Nota: comunicação nas três dimensões: cognitiva, normativa e expressiva.

b) Analisar se os sistemas e práticas atuais das interfaces concorrem positivamente ou negativamente para a obtenção dos objetivos do sistema de produção.

c) Idem com relação aos objetivos específicos de cada uma das áreas que atuam diretamente no sistema de produção.

d) Outros. 